\title{
The role of polycyclic aromatic hydrocarbons in atherosclerosis : implications for chemical atherogenesis
}

Citation for published version (APA):

Curfs, D. M. J. (2004). The role of polycyclic aromatic hydrocarbons in atherosclerosis : implications for chemical atherogenesis. [Doctoral Thesis, Maastricht University]. Universiteit Maastricht. https://doi.org/10.26481/dis.20040618dc

Document status and date:

Published: 01/01/2004

DOI:

10.26481/dis.20040618dc

Document Version:

Publisher's PDF, also known as Version of record

Please check the document version of this publication:

- A submitted manuscript is the version of the article upon submission and before peer-review. There can be important differences between the submitted version and the official published version of record.

People interested in the research are advised to contact the author for the final version of the publication, or visit the DOI to the publisher's website.

- The final author version and the galley proof are versions of the publication after peer review.

- The final published version features the final layout of the paper including the volume, issue and page numbers.

Link to publication

\footnotetext{
General rights rights.

- You may freely distribute the URL identifying the publication in the public portal. please follow below link for the End User Agreement:

www.umlib.nl/taverne-license

Take down policy

If you believe that this document breaches copyright please contact us at:

repository@maastrichtuniversity.nl

providing details and we will investigate your claim.
}

Copyright and moral rights for the publications made accessible in the public portal are retained by the authors and/or other copyright owners and it is a condition of accessing publications that users recognise and abide by the legal requirements associated with these

- Users may download and print one copy of any publication from the public portal for the purpose of private study or research.

- You may not further distribute the material or use it for any profit-making activity or commercial gain

If the publication is distributed under the terms of Article $25 \mathrm{fa}$ of the Dutch Copyright Act, indicated by the "Taverne" license above, 
The role of Polycyclic Aromatic Hydrocarbons in atherosclerosis: Implications for chemical atherogenesis 
(C) D.M.J. Curfs, Maastricht 2004 ISBN 90-6464-954-5

Vormgeving:

Omslagontwerp:

Printed by:
Judith Vogels-Curfs / Daniëlle Curfs Daniëlle Curfs

.. Grafisch Bedrijf Ponsen \& Looijen B.V. 


\section{The role of \\ Polycyclic Aromatic Hydrocarbons in atherosclerosis: \\ Implications for chemical atherogenesis}

\section{PROEFSCHRIFT}

ter verkrijging van de graad van doctor aan de Universiteit Maastricht, op gezag van de Rector Magnificus, Prof. mr. G.P.M.F. Mols volgens het besluit van het College van Decanen, in het openbaar te verdedigen op vrijdag 18 juni 2004 om 12.00 uur.

door

Danitle Maria Jozef Curfs

geboren te Voerendaal, 17 december 1976 


\section{Promotores:}

Prof. dr. F.J. van Schooten

Prof. dr. M.J.A.P. Daemen

\section{Beoordelingscommissie:}

Prof. dr. E.F.M. Wouters (voorzitter)

Prof. dr. M.H. Hofker

Prof. dr. H. van Loveren

Dr. J.G. Maessen

Prof. dr. C.P. Wild (University of Leeds, UK)

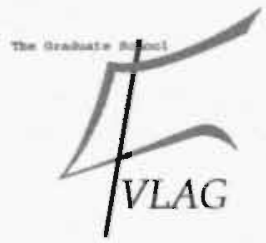

Financial support by the Netherlands Heart Foundation, and the Dr. Ir. van de Laar Stichting for the publication of this thesis is gratefully acknowledged. 
As we go down life's lonesome highway,

the hardest thing to do is to find a friend or two.

That helping hand, someone who understands.

If you feel you've lost your way someone who will say:

"I'll show you"

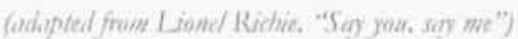





\section{Contents}

Abbreviations

Chapter 1. General Introduction 13

Epidemiology 15

Pathogenesis of atherosclerosis $\quad 15$

$\begin{array}{ll}\text { Theories concerning atherosclerosis } & 17\end{array}$

Mouse models of atherosclerosis 20

Polycyclic aromatic hydrocarbons $\quad 21$

PAHs and atherosclerosis $\quad 25$

Aim and outline of this thesis $\quad 33$

Chapter 2. Modulation of plasma lipid levels affects benzo[a]pyrene-induced DNA damage in tissues of two hyperlipidemic mouse models

Chapter 3. Benzo[a]pyrene enhances lipid peroxidation induced DNA damage in aorta of apolipoprotein E knockout mice

Chapter 4. Chronic exposure to the carcinogenic compound benzo[a]pyrene induces larger and phenotypically different atherosclerotic plaques in ApoEknockout mice

Chapter 5. Polycyclic aromatic hydrocarbons induce an inflammatory plaque phenotype irrespective of their DNA damaging properties

Chapter 6. Upregulation of TGF $\beta$ gene expression in the aortic arch of apolipoprotein $\mathrm{E}$ knockout mice after acute exposure to benzo[a]pyrene 
$\begin{array}{ll}\text { Chapter 7. General Discussion } & 123\end{array}$

Main findings of this thesis 125

Chemical atherogenesis: the response-to-injury hypothesis and the monocional hypothesis $\quad 125$

PAHs and the original initiation-promotion-progression idea of atherogenesis 126

Chemical atherogenesis: a revision of the believed pathogenesis 128

Limitations, concluding remarks and future direcrions $\quad 130$

$\begin{array}{ll}\text { Summary } & 137\end{array}$

$\begin{array}{ll}\text { Samenvatting } & 141\end{array}$

$\begin{array}{ll}\text { Dankwoord } & 145\end{array}$

$\begin{array}{ll}\text { Curriculum Vitae } & 149\end{array}$ 


\section{Abbreviations}

AA

AC

$\mathrm{AH}$

$\mathrm{AHH}$

AhR

ANT

ApoE

ApoE-KO

APC

ARNT

ASMA

$\mathrm{B}[\mathrm{a}] \mathrm{P}$

$\mathrm{B}[\mathrm{e}] \mathrm{P}$

bFGF

BPDE

cDNA

CHD

CVD

CYP450

DNA

DMBA

$\varepsilon \mathrm{d} A$

$\varepsilon \mathrm{d} C$

EDTA

e.g.

ETS

FACS

FITC

GAPdH

HDL.

H\&E

$\mathrm{HO}$.

HNE

HUVEC

IFN $\gamma$

ICAM-1

i.c.

IGF

Il

LDL abdominal aorta

dibenz $[a, c]$ anthracene

dibenz $[\mathrm{a}, \mathrm{h}]$ anthracene

arylhydrocarbonhydroxylase

arylhydrocarbon receptor

anthracene

apolipoprotein $\mathrm{E}$

apolipoprotein E knockout

adenomatous polyposis coli

arylhydrocarbon receptor nuclear translocator

$\alpha$-smooth muscle actin

benzo[a]pyrene

benzo[e]pyrene

basic fibroblast growth factor

benzo[a]pyrene-7,8-dihydrodiol-9,10-epoxide

copy deoxyribo nucleic acid

coronary heart disease

cardiovascular disease

cytochrome P450

deoxyribo nucleic acid

7,12-dimethylbenz[a]anthracene

$1, \mathrm{~N}^{6}$-ethenodeoxyadinosine

$3, \mathrm{~N}^{4}$-ethenodeoxycitidine

ethylenediaminetetracetic acid

exempli gratia (for example)

environmental tobacco smoke

fluorescence activated cell sorting

fluorescein isothiocyanate

glyceraldehyde-3-phosphate dehydrogenase

high-density lipoprotein

haematoxylin and eosin

hydroxyl radical

trans-4-hydroxy-2-nonenal

human vascular endothelial cell

interferon gamma

intracellular adhesion molecule 1

id est (that is)

insuline like growth factor

interleukin

low-density lipoprotein 


$\begin{array}{ll}\text { LPO } & \text { lipid peroxidation } \\ \text { 3-MC } & \text { 3-methylcholanthrene } \\ \text { MCP-1 } & \text { macrophage chemoattractant protein 1 } \\ \text { MFO } & \text { mixed-function oxidase } \\ \text { NA } & \text { not available } \\ \text { NAC } & \text { N-acetylcysteine } \\ \text { ND } & \text { not detectable } \\ \text { nucl. } & \text { nucleotides } \\ \text { O }- \text { - } & \text { superoxide anion } \\ \text { 8-oxo-dG } & \text { 8-oxodeoxyguanosine } \\ \text { OGG1 } & \text { 8-oxoguanine glycosylase } \\ \text { OxLDL } & \text { oxidized low-density lipoprotein } \\ \text { PAH } & \text { polycyclic aromatic hydrocarbon } \\ \text { PCNA } & \text { proliferating cell nuclear antigen } \\ \text { PDGF } & \text { platelet derived growth factor } \\ \text { PE } & \text { phycoeritherin } \\ \text { PEI } & \text { polyethyleneimine } \\ \text { PUFA } & \text { polyunsaturated fatty acid } \\ \text { RNA } & \text { ribo nucleic acid } \\ \text { ROS } & \text { reactive oxygen species } \\ \text { RNS } & \text { reactive nitrogen species } \\ \text { RT-PCR } & \text { real time polymerase chain reaction } \\ \text { SD } & \text { standard deviation } \\ \text { SEM } & \text { standard error of the mean } \\ \text { SET } & \text { sodium EDTA Tris } \\ \text { SDS } & \text { sodium dodecyl sulfate } \\ \text { SMC } & \text { smooth muscle cell } \\ \text { SOD } & \text { superoxide dismutase } \\ \text { SR } & \text { Show Racer } \\ \text { TA } & \text { thoracic aorta } \\ \text { TGF } & \text { transforming growth factor beta } \\ \text { TLC } & \text { thin layer chromatography } \\ \text { TNF } & \text { tumor necrosis factor } \\ \text { TPA } & \text { 12-O-tetradecanoylphorbol-13-acetate } \\ \text { TUNEL } & \text { terminal deoxyUric nick end labeling } \\ \text { VCAM } & \text { vascular cell adhesion molecule } \\ \text { WC } & \text { White Carneau } \\ \text { XP } & \text { xeroderma pigmentosum } \\ & \end{array}$


-

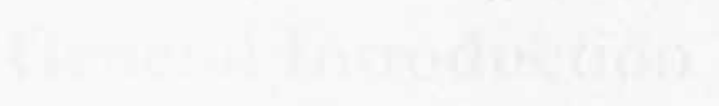





\section{Chapter 1}

\section{General Introduction}

Daniëlle M.J. Curfs, Mat J.A.P. Daemen, Frederik J. van Schooten 



\section{Epidemiology}

Cardiovascular diseases (CVDs) are the most important cause of morbidity and mortality in the developed countries. ${ }^{1}$ In 2001 in the Netherlands, 48,437 people died of CVDs, ${ }^{2}$ accounting for $35 \%$ of all causes of death. CVDs are the number one contributor to death in the Netherlands. The prevalence of CVDs is not gender specific. In absolute numbers 23,156 males and 25,281 females died in the Netherlands in 2001 due to CVDs. This accounts for $34 \%$ and $35 \%$ of the relative gender specific mortality rates respectively.

Atherosclerosis, the pathological state associated with CVD, is a disease of the large and medium-sized arteries. It is the result of the progressive accumulation of smooth muscle cells, lipids and connective tissue within the intima. Marchand first introduced the term "atherosclerosis" in 1904 to describe the prominent arterial lesion. ${ }^{3}$ In Greek, ather means gruel, and skleros means hard. Atherosclerosis is a specific type of arteriosclerosis (from the Greek arteria, meaning artery) which is a general term used to describe the hardening of arteries.

Atherosclerosis is considered as probably one of the longest slumbering degenerative diseases. This silently progressing disease starts as early as childhood, ${ }^{4}$ but it isn't until middle life that it might reveal its first clinical symptoms. Although a lot of effort has been made over the years to better understand this silent killer, there are still many black boxes regarding the onset and progression of this disease.

In this first chapter a general introduction will be given on atherosclerosis including its pathogenesis in humans, the response-to-injury theory, the monoclonal theory, and a description of the atherosclerotic mouse models used in the studies of this thesis. The main metabolic pathways of polycyclic aromaric hydrocarbons and especially of benzo[a]pyrene and benzo[e]prene will be described, after which the role of PAHs in atherosclerosis is outlined by giving dara on animal, in nimo and human studies. The chapter will be concluded with the hypothesis of this thesis and an overview of the studies described in the following chapters.

\section{Pathogenesis of Atherosclerosis}

\section{The normal artery}

The normal artery is composed of three distinct layers, as shown in Figure 1.1. Working from the luminal side outwards, these layers are defined as the mnim intima, the tunio media and the muica adrentitio. The tunica intima is comprised of endothelial cells and connective tissue rich in elastic fibers. The inner lining of 
endothelial cells is crucial in maintaining the normal homeostasis of the artery. The endothelium provides a smooth and continuous, thrombotically inert surface which prevents disturbances in blood flow and blood clotting. ${ }^{5}$ Furthermore, by locally releasing vasoactive compounds like nitric oxide, it plays a pivotal role in the regulation of the blood pressure. The tunica media consists of continuous layers of circular smooth muscle cells (SMCs) each layer separated by elastic fibers. The most outer layer of the artery is the tunica adventitia. This relatively thin layer consists mainly of elastic and collagen fibers. In the adventitia nerves, lymphatic vessels and tiny blood vessels (vasa vasorum: vessels of the vessels) can be found.

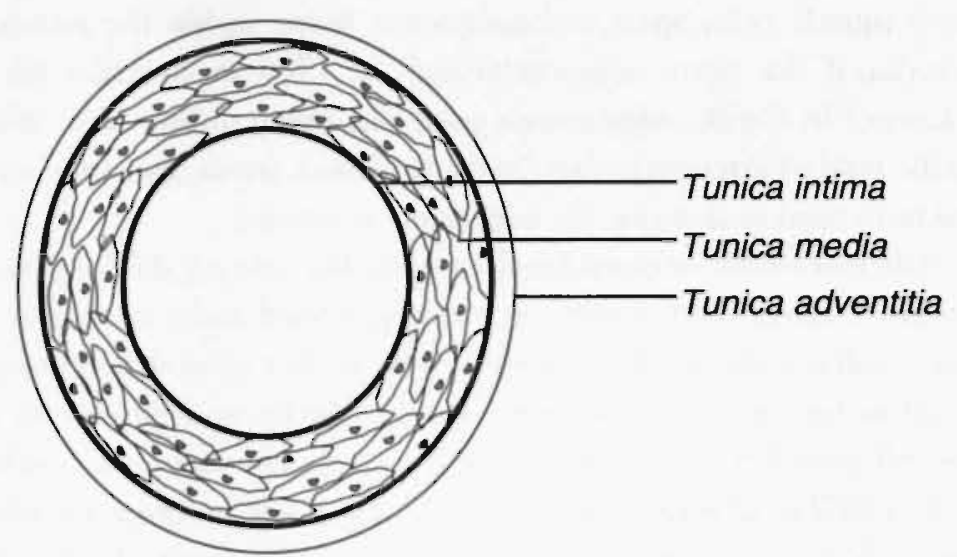

Figure 1.1 Schematic representation of a normal artery, showing the three tunicae.

\section{Patbogenesis of atberosclerosis}

The earliest observable change in the vessel wall associated with atherosclerosis is the eccentric intimal thickening. ${ }^{6}$ This intimal thickening is the result of accumulation of smooth muscle cells in the intima and occurs mainly at sites of disturbed blood flow e.g. at bifurcarions. ${ }^{7}$ These sites of intimal thickening are prone to lipid retention, thereby forming the initial lesion. As a result monocytes are attracted which migrate through the endothelial layer into the arterial wall. There they proliferate and differentiate into macrophages which take up the accumulated lipoproteins, forming the so called 'foam cells' ${ }^{8}$ This early lesion is called fatry streak or, when taken together with the initial lesion, an intimal xanthoma. ${ }^{19,10}$ Macroscopically, these fatty streaks can be seen as yellow-colored patches on the intimal surface of the arteries. It has to be noted that this fatty streak is not per definition the result of intimal thickening, but can in some cases 
also be an event on its own. As the disease progresses, monocyte recruitment and lipid accumulation continues. An important feature of this stage is that the lipid droplets now also accumulate extracellularly in pools just below the macrophage layers. These single extracellular lipid pools keep on growing until they finally melt together to form a core of extracellular lipids. From this point on the disease is called advanced (Figure 1.2) and the lesion is defined as 'atheroma'. 911 SMCs migrate into the intima, the amount of fibrous tissue (collagen) increases finally resulting in the formation of a fibrous cap covering the lipid core. This lesion is called a fibro-atheroma. As long as the lipid core(s) are not too large and the fibrous cap is thick the plaque phenotype is considered stable. A large lipid core combined with a thin fibrous cap increase the risk for plaque rupture. This latter plaque phenotype is described as unstable. If plaque rupture occurs, the fibrous cap will be disrupted and infiltrated with monocytes and macrophages. At the site of rupture or hemorrhage, thrombogenic material will develop. ${ }^{11,12}$ Atherosclerosis associated morbidity and mortality is often characterized by plaque rupture or hemorrhage and the subsequent occlusion of the affected blood vessel.

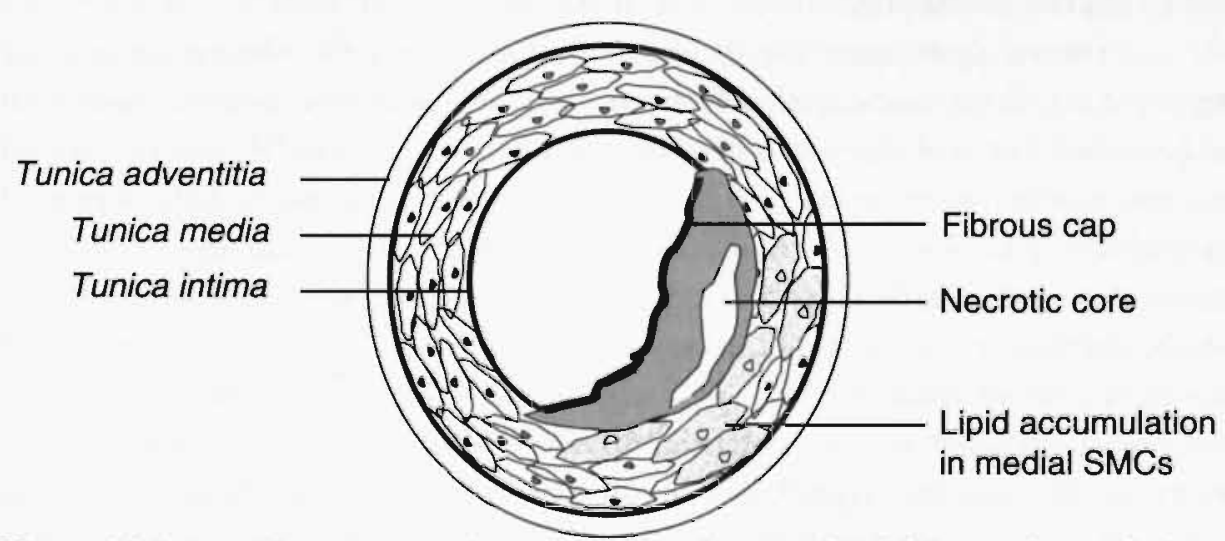

Figure 1.2 Schematic representation of a diseased artery, in which an advanced plaque causes luminal narrowing.

\section{Theories concerning atherosclerosis}

To explain the development of atherosclerosis, several theories have been postulated over the years. A main contribution in the understanding of atherosclerosis has been made by the German pathologist Rudolph Virchow (1821-1905). It was Virchow who, as early as 1856, more or less laid the foundation for the currently holding theories on atherosclerosis. He proposed that 
the primary fatty and atheromatous degeneration resulted from injury to the vessel wall. ${ }^{13}$ According to his ideas, atherogenesis involves a combination of inflammatory and proliferative responses within the artery wall. Although the basis was set, it wasn't until more than a century later that the presently believed most important 'response to injury theory' and the 'monoclonal theory' were formulated.

\section{Response-to-injury bypothesis}

The response-to-injury hypothesis as formulated by the group of $\mathrm{R}$. Ross in $1973^{14}$ can be seen as the extended ideas of Virchows' inflammatory theory. The original response-to-injury theory states that some form of injury to the arterial endothelium causes endothelial denudation and that this is the first step in atherosclerosis. The suggested injuries that would cause this dysfunction included hyperlipidemia, hypertension, infections, cigarette smoking, diabetes mellitus and even genetic alterations. At sites of injury were the endothelium is lost, the underlying collagen is directly exposed to the blood and blood derived compounds like platelets. These platelets can then adhere to these subendothelial sites, and thereby trigger platelet aggregation and platelet-derived factors which in turn will lead to migration and proliferation of medial smooth muscle cells. ${ }^{14}$

Twenty years later, the theory was adjusted and the ideas regarding the trigger of the disease were shifted from endothelial denudation towards endothelial dysfunction. Although there are different sources of injury, oxLDL was recognized as a major contributor to this dysfunction. Furthermore, subendothelial trapping of lipoproteins was observed. Besides the earlier observed role for the endothelial cells and smooth muscle cells, the importance of macrophages and T-lymphocytes, which migrate to the sites of injury under influence of growth factors and cytokines, was recognized. ${ }^{15,16} \mathrm{It}$ is now thought that, regardless of the cause of the endothelial dysfunction and the mechanisms involved, the main reaction will be a compensation for the endothelial damage as an attempt to maintain normal homeostasis. The compensatory response of the artery wall involves a specialized chronic inflammatory-fibroproliferative reaction in which endorhelial cells, monocytes/macrophages, T-lymphocytes, and smooth muscle cells are the key players. The process is mediated by a broad scala of adhesion molecules (such as selectins, ICAM-1 and VCAM), growth factors (PDGF, TGF $\beta$, IGF, bFGF), cytokines (e.g. IFN $\gamma, \mathrm{Il}-1, \mathrm{Il}-2, \mathrm{TNF} \alpha$ ) and chemokines (MCP1, Il-8), and will eventually result in atherosclerotic plaque formation.

\section{Monoclonal theory}

The monoclonal theory originates from 1973 when Benditt and Benditt published their paper entitled: "Evidence for a monoclonal origin of human atherosclerotic 
plaques". ${ }^{17}$ In this paper, Benditt and Benditt proposed an alternative to the injuryrepair theory of atherosclerosis. They stated that when atherosclerotic plaques were indeed the result of either a response to injury akin wound healing, or a reaction to a growth stimulant or even the result of thrombus formation in the vessel wall, the plaques would be expected to be polyclonal. However, they showed that the cells of spontaneous atherosclerotic lesions differ from cells of normal artery wall and cells from a repair site. The cells in the plaques were smaller and there was a lack of intercellular junctions, suggesting that the cells of a plaque are either derived from a cell population different from the normal arterial media or that they are transformed cells. If the latter would be the case, atherosclerotic plaques might be of monoclonal origin, like the benign smooth muscle tumors of the uterus. The monoclonality of these benign uterine smooth muscle cell tumors was established by investigation of the X-linked glucose-6-phosphate dehydrogenase isoenzymes. Two isoforms $\mathrm{A}$ and $\mathrm{B}$ of these enzymes are known, and since one of the two $\mathrm{X}$ chromosomes is randomly inactivated in female cells during embryonic development, women heterozygous for these enzymes exhibit mixtures of the $\mathrm{A}$ and $\mathrm{B}$ enzymes. ${ }^{18}$ If a tumor would be of monoclonal origin i.e. is derived by the proliferation of a single cell, only one isoform should be present, as was the case in the uterine smooth muscle tumors. ${ }^{19}$ When Benditt and Benditt applied this technique to atherosclerotic plaques, they found that individual plaques from various regions of the human aorta and common iliac arteries exhibited indeed enzyme patterns consistent with a monoclonal origin, while normal non-diseased sections of the artery wall exhibited a heterozygous enzyme pattern indicating polyclonality. Based on these results they hypothesized that the injury to the vessel wall leading to the atherosclerotic plaque response could very well be due to chemical mutagens or viruses. The original monoclonal character of the fibrous plaque as described by Benditt and Benditt has later been confirmed by others. ${ }^{17,20-}$ ${ }^{22}$ However, some 10 to 15 percent of the fibrous plaques exhibit a heterozygous enzyme phenotype and the evidence linking the SMC to the monoclonality was indirect and speculative. Moreover, there was criticism on the fact that the monoclonality could only be applied to the smooth muscle cells and excluded the macrophages, which are blood derived and polyclonal..$^{23}$ Although Stemme $t$ at..$^{24}$ proved the T-lymphocyte to be polyclonal, it wasn't until more than twenty years after the original monoclonal theory was postulated, that the actual proof came that it was indeed the smooth muscle cell that caused the monoclonal expansion. ${ }^{25}$ By using advanced PCR and microdissection techniques, Murry et al.25,26 proved that 1) the smooth muscle cell is responsible for the monoclonal plaque feature and 2) the vessel wall is not entirely polycional, but consists of large patches of monoclonally expanded cells. The mechanism underlying the monoclonal 
proliferation of SMCs is not known. It could be due to the proliferation of SMCs derived from the monoclonal vessel wall patches. However, as originally suggested, it could also be the result of generic DNA damage of the SMCs, causing mutations and an increase in the proliferation rate of a specific clone of SMCs. Another idea is that SMCs are derived from local stem cells that differentiate and replicate. These cells could migrate to the intima where they, under certain stimulating conditions, can proliferate and form a monoclonal plaque. ${ }^{27} \mathrm{~A}$ final suggestion is the apoptotic advantage of some specific SMCs, which will results in a monoclonal plaque phenotype. ${ }^{28}$

\section{Mouse models of atherosclerosis}

Since the atherogenic lesion development in humans is a complex and chronic process, several animal models have been used to study the pathogenesis of atherosclerosis in vivo. In recent years, especially the use of mouse models has contributed to a better understanding of the development of atherosclerotic plaques. The numerous inbred strains of mice have proven a useful tool to study specific genomic loci with a phenotype..$^{29}$ However, in general the mouse is highly resistant to the development of atherosclerosis; plasma cholesterol levels are low and most of the cholesterol is transported via the high-density lipoproteins (HDL). Drastic diet interventions containing high cholesterol and fat levels together with cholic acid to block cholesterol conversion into bile acids are necessary to induce rather small and simple atherosclerotic plaques. The C57BL/6 mouse is considered as the standard inbred mouse strain susceprible for diet-induced arherosclerosis. On a hyperlipidemic diet, the C57BL/6 mouse will eventually develop atherosclerotic lesions in the aortic root. The lesions are characterized as small foam cell plaques, which can eventually develop into more advanced lesions containing cellular debris and collagen. Overall, these lesions are small and will to no extent reach the advanced phenotype as is clinically relevant in humans. Furthermore, the required diet contains not only unphysiological high concentrations of cholesterol but also cholic acid, which works proinflammatory. ${ }^{30}$

With the development of transgenic and gene targeting techniques, a broad array of new and more sensitive atherosclerotic mouse models is created. For the studies in this thesis, the apolipoprotein $\mathrm{E}$ knockout (apoE-KO) and the apoE*3-Leiden mouse were used. The apoE-KO mouse is one of the commonly used new models. This mouse was developed in 1992 by two independent laboratories, by means of gene-targeting of the apoE-gene in embryonic stem 
cells.31.32 ApoE functions as a ligand for the receptor-mediated uptake of chylomicron and very low density lipoprotein remnant uptake from the blood by the liver. ${ }^{33}$ The apoE-KO mouse suffers from extreme hyperlipidemia due to a disturbed remnant lipoprotein clearance by the liver. As a result these mice will develop spontaneous atherosclerotic lesions throughout the complete arterial tree as early as 10 weeks of age. Early lesions are characrerized by the presence of macrophage foam cells, intermediate lesions containing foam cells and smooth muscle cells come apparent from 15 weeks of age. The fibrous plaque occurred after 20 weeks. However, although the phenotype of the atherosclerotic lesions in apoE-KO mouse resembles the human situation to some extent, no spontaneous plaque rupture will occur.

A less severe transgenic atherosclerotic mouse model is the apoE*3Leiden mouse. This mouse model carries the human apoE*3-Leiden mutation resulting in hyperlipoproteinemia, which becomes more prominent during cholesterol feeding. ${ }^{33}$ Compared to the apoE-KO mouse, the apoE*3-Leiden mouse is less susceptible for the development of atherosclerosis. Upon feeding a high fat high cholesterol diet, the apoE*3-Leiden mouse will develop complex atherosclerotic lesions with an extracellular lipid core covered by a fibrous cap. ${ }^{34}$ However, as in the C57BL/ 6 mouse cholic acid has to be present in the HFC diet, which could have an inflammatory confounding effect especially after longterm diet interventions.

\section{Polycyclic Aromatic Hydrocarbons}

\section{Introduction}

Over the years, the recognition of the modulating influences of exogenous agents on a wide variety of diseases and illnesses has grown. One of these renewed insights includes the role of environmental chemicals like polycyclic aromatic hydrocarbons in the development of atherosclerosis. ${ }^{35}$ As long as mankind exists, it has been confronted with the exposure to this large group of strucrurally related, potentially carcinogenic chemicals, called polycyclic aromatic hydrocarbons (PAHs). ${ }^{36}$ PAHs consist of multiple fused benzene rings and are formed during the incomplete combustion of organic materials. Human exposure has increased drastically with the industrialization, since PAHs are also abundantly produced by power plants, domestic and industrial-heating systems, combustion engines and refuse burning. Another more localized, but very important source is formed by tobacco smoke. ${ }^{37}$ The threat of exposure to these compounds lies in the fact that they are capable of damaging cellular macromolecules, and many of these PAHs 
have proven to be powerful carcinogens in experimental animals. ${ }^{38}$ However, PAHs are not only associated with the development of various cancers but also with cardiovascular diseases (CVDs), loss of fertility and immunosuppression. ${ }^{39.40}$

PAHs are lipophilic and if they were not metabolized, they would accumulate in body fat. Paradoxically, this metabolism, meant for detoxification, can lead to the formation of toxic PAH metabolites. After entering the organism either via ingestion, inhalation or dermal uptake, PAHs are initially oxygenated predominantly via cytochrome $\mathrm{P} 450$-containing microsomal mixed-function oxidases (MFOs), ${ }^{37,41}$ The formed intermediate oxygenated metabolites include epoxides, phenols and quinones. These products can be further metabolized via additional oxygenation or hydration into dihydrodiol, diolepoxides, or conjugation with the water-soluble glutathione, glucuronide or sulfate. These conjugates are more polar and can therefore easily be excreted from the cells and the organism. The reactions in which the dihydrodiol epoxides are formed lead to metabolites that are very reactive and able to form covalent bindings with proteins, RNA and DNA.

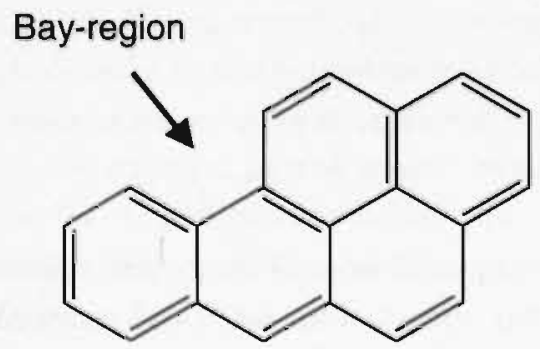

Benzo[a]pyrene

\section{Bay-region}

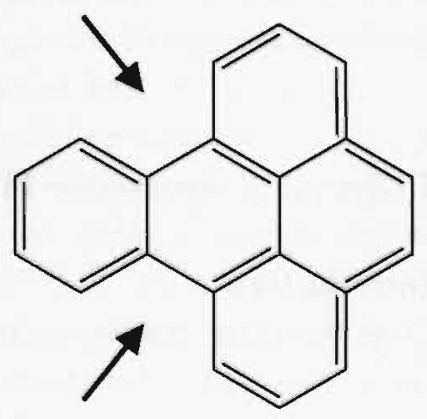

Bay-region

\section{Benzo[e]pyrene}

Figure 1.3 Chemical structure of Benzo[a]pyrene and Benzo[e]pyrene.

\section{Benzo[a]pyrene}

A very well known mutagenic, carcinogenic, teratogenic and atherogenic $\mathrm{PAH}$ is benzo[a]pyrene $(\mathrm{B}[\mathrm{a}] \mathrm{P}) . \mathrm{B}[\mathrm{a}] \mathrm{P}$ is abundantly present in the environment and consists of 5 benzene rings annealed to each orher as shown in Figure 1.3. Afrer 
entering the body, B[a]P binds to the cytosolic arylhydrocarbon receptor (AhR), a ligand-dependent basic helix-loop-helix transcription factor. This binding triggers the $\mathrm{AhR}$ to translocate to the nucleus, where it associates with the AhR nuclear translocator (ARNT) and interacts with xenobiotic responsive elements of responsive genes. ${ }^{42}$ It is via this mechanism that carcinogen-metabolizing enzymes like cytochrome P450s are upregulated. This is the first step in B[a]P metabolism. From here, several metabolic pathways can lead to various $\mathrm{B}[\mathrm{a}] \mathrm{P}$-derived toxic metabolites (Figure 1.4).43

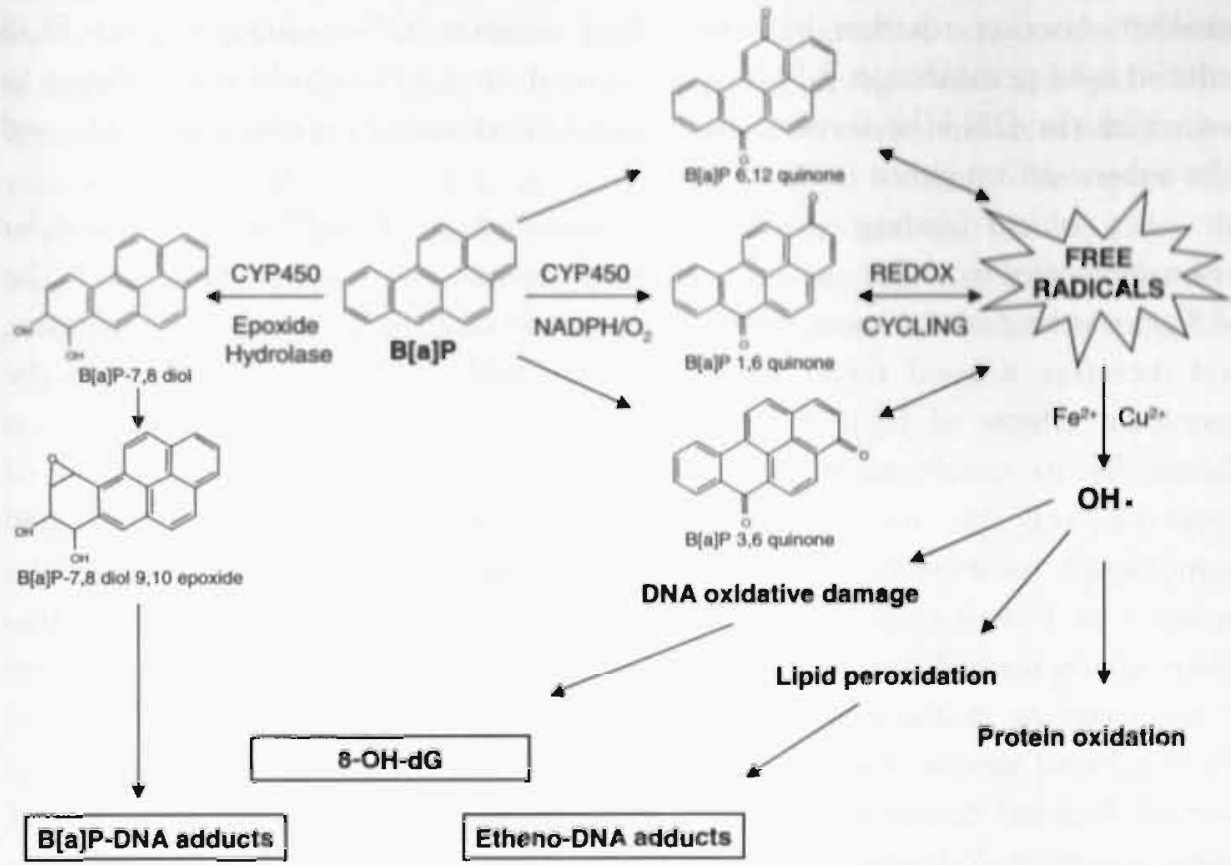

Figure 1.4 Metabolic pathways by which benzola]pyrene (B[a]P) derived toxic metabolites are formed.

The most toxic and ultimate carcinogenic metabolite is the so-called bay region B[a]P-7,8-diol epoxide (BPDE). ${ }^{36,44}$ BPDE is highly reactive and can covalently bind to DNA, mainly between the 2-amino group of guanine $\left(\mathrm{N}^{2}\right)$ and the C10-position of B[a]P (BPDE-N²-dG). BPDE can be formed by the cytochrome P450 catalyzed epoxidation of $\mathrm{B}[\mathrm{a}] \mathrm{P}$ into $\mathrm{B}[\mathrm{a}] \mathrm{P}-7,8$-epoxide. This epoxide can then serve as a substrate for epoxide hydrolase by which B[a]P-7,8diol is formed. A second cytochrome P450-catalyzed epoxidation reaction can 
ultimately lead to the formation of BPDE. Other toxic B[a]P derivatives can be formed via one-electron oxidation which leads to the formation of quinones. B[a]P quinones are formed after $\mathrm{B}[\mathrm{a}] \mathrm{P}$ oxidation via cytochrome $\mathrm{P} 450 \mathrm{~s}$ and during reactions with peroxidases. Via redox cycling, these quinones can form highly toxic reactive oxygen species (ROS), or bind directly and covalently to cellular macromolecules. ${ }^{45} \mathrm{~B}[\mathrm{a}] \mathrm{P}$ quinones are capable of producing superoxide anions $\left(\mathrm{O}_{2} \cdot\right)$ which can be enzymatically converted to $\mathrm{H}_{2} \mathrm{O}_{2}$ or directly produce $\mathrm{H}_{2} \mathrm{O}_{2}$. If not detoxified, $\mathrm{H}_{2} \mathrm{O}_{2}$ produces $\mathrm{ROS}$ such as hydroxyl radicals (HO) via the Fenton reaction. HO can lead to oxidative DNA damage like the stable 8oxodeoxyguanosine adduct (8-oxo-dG) and single and double DNA-strand breaks. ${ }^{\$ 6}$ Another reaction by which $\mathrm{B}[\mathrm{a}] \mathrm{P}$ induces DNA damage is via ROS induced lipid peroxidation (LPO). A number of these LPO products are known to react with the DNA by forming the stable $1, \mathrm{~N}^{6}$-ethenodeoxyadinosine $(\varepsilon \mathrm{dA})$ and $3, \mathrm{~N}^{4}$-ethenodeoxycitidine ( $\left.\mathrm{EdC}\right){ }^{47}$

Covalent binding of the reactive metabolites of $\mathrm{B}[\mathrm{a}] \mathrm{P}$ with vital cellular macromolecules can alter or inactivate their normal physiological function. ${ }^{48}$ The p53 gene is one of the most important genes in maintaining normal homeostasis, and therefore a good target to study the possible biological relevance for the genotoxic effects of $\mathrm{B}[\mathrm{a}] \mathrm{P} .{ }^{49}$ The different functions of $\mathrm{p} 53$ are numerous as shown by its involvement in the suppression of transcription, induction of apoptosis, cell cyle arrest, DNA repair, suppression of genetic instability and homologous recombination, interaction with a large number of viral and cellular proteins, and involvement in development and differentiation..$^{50}$ It is proven that $\mathrm{B}[\mathrm{a}] \mathrm{P}$, which forms DNA adducts mainly at guanines, predominantly induces $\mathrm{G}$ to $T$ transversions in the $\mathrm{p} 53$ gene. ${ }^{51}$ This mutation in $\mathrm{p} 53$ was directly linked to B[a]P-induced murine skin tumors..$^{52}$ Denissenko $e t a l .^{53}$ proved that incubation of normal human bronchial epithelial cells with BPDE resulted in $G$ to $T$ transversions at codons 157,248 , and 273 of the p53 gene, which are the same major mutational hotspots as in human lung cancer. Although p53 plays a role in atherosclerotic plaque development, ${ }^{54,55}$ it is not known whether B[a]P-induced mutations in p53 are also linked to progression of cardiovascular diseases.

\section{Benzo[e]pyrene}

The PAH benzo[e]pyrene (B[e]P) is structurally related to $\mathrm{B}[\mathrm{a}] \mathrm{P}$ and abundantly present in the environment. ${ }^{56}$ Because of its very weak or non-carcinogenic potential not much interest has been shown for this PAH. B[a]P and B[e]P differ only in the position at which the benzo-ring is annealed to pyrene (Figure 1.3). $\mathrm{B}[\mathrm{e}] \mathrm{P}$ is a symmetric $\mathrm{PAH}$ with two bay regions. This suggests that $\mathrm{B}[\mathrm{e}] \mathrm{P}$ should be able to form carbonium ions more readily than PAHs without a bay region. ${ }^{57} \mathrm{It}$ 
is postulated that the presence of bay regions and subsequent epoxidation explain the carcinogenicity of certain hydrocarbons. However, data of both animal and human carcinogenicity studies showed low carcinogenicity of B[e]P. ${ }^{58-60}$ Several mechanistic studies have been performed to explain the unexpected low activity of $B[e] P$. The first observation was that B[e]P does not activate the Ah-receptor. Since the $\mathrm{Ah}$-receptor is implicated in up-regulation of carcinogen-metabolizing enzymes like cytochrome P450s, the lack of B $[\mathrm{e}] \mathrm{P}$ to trigger this receptor suggests that there is no induction of the necessary activating enzymes. ${ }^{61}$ Studies with synthetic $B[e] P$ bay region tetrahydroepoxide showed a very high mutagenicity, suggesting that these metabolites have the necessary activity to be ultimate carcinogens. ${ }^{62}$ However, even when $\mathrm{B}[\mathrm{e}] \mathrm{P}$ 9,10-dihydrodiol was incubated with activated rat liver microsomes, only non-bay region diolepoxides are formed and little or no bay region diolepoxides, ${ }^{57}$ probably due to steric hinderence in the bay region. Even when bay region dihydrodiols are formed, the quasi-axial conformations of the hydroxyl groups of the dihydrodiols would make the molecule bulkier and more polar compared to non-bay region dihydrodiols. As a consequence, none or only very low levels of B[e]P-derived DNA adducts will be formed.

\section{PAHs and atherosclerosis}

\section{Animal studies}

The idea that atherosclerotic plaques might be benign smooth muscle cell tumors of the aortic vessel wall taised the question of the possible involvement of environmental carcinogens in atherogenesis. The most evident proof for the involvement of environmental carcinogens as for instance PAHs has been provided by animal studies published over the years (Table 1.1). The first animal study to investigate the role of carcinogenic PAHs in the development of atherosclerosis was performed in 1977 by Albert $\theta t$ al..$^{63}$ They injected chickens weekly for 13-18 weeks with B[a]P and the even more carcinogenic PAH 7,12dimethylbenz(a)anthracene (DMBA). Both carcinogens were shown to be accelerators of the arherogenic process, while DMBA was more potent than B[a]P in progressing the disease. Based on the restricted histology performed, it was concluded that the atherosclerotic plaques of the carcinogen-treated birds were 
Table 1.1 Animal studies suggesting the involvement of environmental PAHs in atherogenesis.

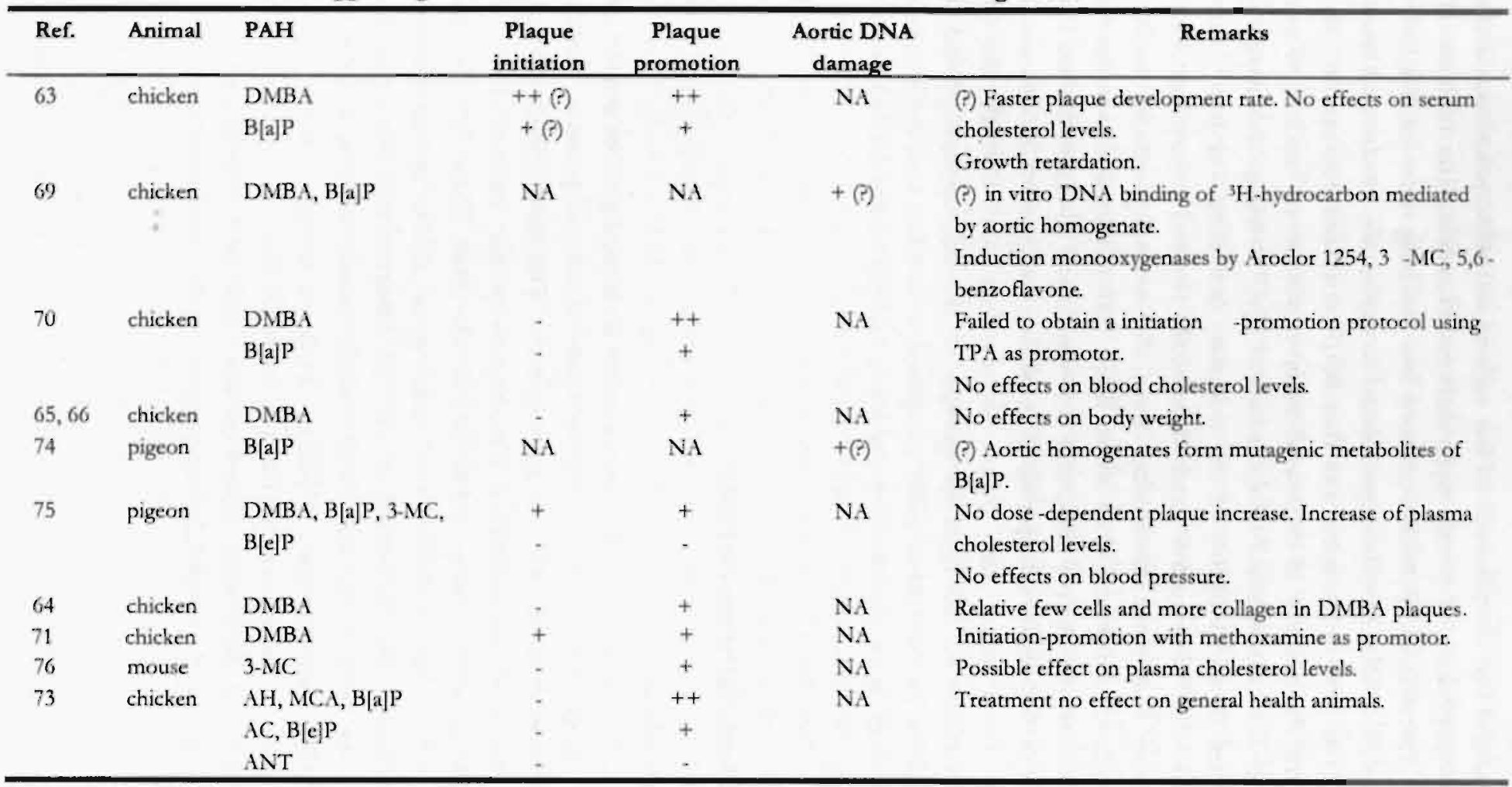


Table 1.1 (Continued) Animal studies suggesting the involvement of environmental PAHs in atherogenesis.

\begin{tabular}{|c|c|c|c|c|c|c|}
\hline Ref. & Animal & PAH & $\begin{array}{l}\text { Plaque } \\
\text { initiation }\end{array}$ & $\begin{array}{l}\text { Plaque } \\
\text { promotion }\end{array}$ & $\begin{array}{c}\text { Aortic DNA } \\
\text { damage }\end{array}$ & Remarks \\
\hline 72 & chicken & DMBA & $\mathrm{NA}$ & NA & $+(?)$ & $\begin{array}{l}\text { (?) DNA from DMBA-accelerated plaques has } \\
\text { transforming capacity in NIH } 3 \text { T } 3 \text { cells. } \\
\text { No activation of oncogenes Ha-ras, Ki-ras, src or myc. }\end{array}$ \\
\hline 77,78 & rat & $\begin{array}{l}\text { B }[\mathrm{a}] \mathrm{P}, \\
\text { Tobacco smoke }\end{array}$ & $\mathrm{NA}$ & $\mathrm{NA}$ & + & $\begin{array}{l}\text { Decreased body weight in tobacco smoke group. } \\
\text { Reduction DNA adducts by use of chemopreventicum } \\
\text { (NAC, oltipra?). }\end{array}$ \\
\hline 67 & chicken & Tobacco smoke & $=$ & + & + & No difference in plaque distribution. \\
\hline 68 & chicken & $\begin{array}{l}\text { DMBA } \\
\text { tar }\end{array}$ & - & + & $\mathrm{NA}$ & $\begin{array}{l}\text { No effects on body weight. No difference in plaque } \\
\text { location. }\end{array}$ \\
\hline 79 & mouse & Tobacco smoke & - & + & $\mathrm{NA}$ & $\begin{array}{l}\text { No effects on scrum cholesterol levels. } \\
\text { No effects on cellular plaque composition. }\end{array}$ \\
\hline 80 & mouse & Tobacco smoke & - & + & + & $\begin{array}{l}\text { Both tobacco smoke and hypercholesterolemia associated } \\
\text { with increased mitochondrial DNA damage and protein } \\
\text { nitration. Tobacco smoke exposure resulted in decreased } \\
\text { specific activities of mitochondrial enzymes. Tobacco } \\
\text { smoke and hyper cholesterolemia combined, resulted in } \\
\text { increased atherosclerotic lesion formation and even } \\
\text { greater levels of mitochondrial damage. }\end{array}$ \\
\hline
\end{tabular}

DMBA: 7,12-dimethylbenz[a]anthracene, B[a]P: benzo[a]pyrene, 3-MC: 3-methyicholanthrene, B[e]P: benzo[e]pyrene, $\mathrm{AH}$ : dibenz.a.h]anthracene, $\mathrm{AC}$ : dibenz[a,c]anthracene,

ANT: anthracene, NAC: $\mathrm{N}$-acetylcysteine, TPA:12-G-tetradecanoylphorbol-13-acetate, NA: not available. 
morphologically indistinguishable from those in the control birds. Although there was some growth retardation in the carcinogen treated animals, plasma lipid levels were not affected. Subsequent studies using various PAHs confirmed these findings and showed a dose dependent size increase of the arterial lesions. ${ }^{64.68}$ If the mechanism of chemical atherogenesis would have similar characteristics as chemical carcinogenesis, one of the requested conditions would be a biotransforming capacity of the aorta to produce reactive metabolites that can bind to DNA. Bond $e t$ al ${ }^{69}$ reported that chicken aorta homogenates indeed contained inducible monooxygenases that were capable of activating DMBA and B[a]P into metabolites that are mutagenic and can bind to DNA in vitro. With regard to the atherosclerotic plaque development, they not only showed an increase in lesion size, but also in the number of lesions, suggesting that the carcinogens might also act as "initiators" of the atherogenic process. ${ }^{70}$ In an attempt to establish an initiation-promotion sequence in chemical atherogenesis they injected chickens with a single dose of DMBA or $\mathrm{B}[\mathrm{a}] \mathrm{P}$ followed by a weekly administration of the tumor promotor 12-O-tetradecanoylphorbol-13-acetate (TPA) for 20 weeks. This exposure protocol however failed to enhance atherosclerotic lesion formation. Another study did establish a initiation-promotion mechanism in chickens by using DMBA as the initiator and the $\alpha_{1}$-selective adrenergic agonist methoxamine as the promotor. ${ }^{71}$ Moreover, it was proven that DNA from carcinogen-associated cockerel plaques exhibits transforming features in NIH3T3 cells and that subsequent injection of these transformed cells into nude mice elicits tumors that contain cockerel genomic DNA.72 A study linking the carcinogenic potency of PAHs to their atherogenic capacity failed, in that the effects of the moderate and weak or non-carcinogens dibenz $[\mathrm{a}, \mathrm{h}]$ anthracene, dibenz $[\mathrm{a}, \mathrm{c}]$ anthracene and $\mathrm{B}[\mathrm{e}] \mathrm{P}$ were almost similar to those of the strong carcinogens $\mathrm{B}[\mathrm{a}] \mathrm{P}$ and 3merhylcholanthrene. ${ }^{73}$

Studies in arherosclerosis-susceptible and resistant pigeons showed the inducibility of cytochrome-P450-dependent monooxygenases in aorta as was proven in chickens. ${ }^{69,74}$ This inducibility was much higher in the atherosclerosissusceprible White Carneau (WC-2) pigeons than in the atherosclerosis-resistant Show Racer (SR-39) strain. The mutagenicity and cytotoxicity of aortic homogenates from both pigeon strains exposed to $\mathrm{B}[\mathrm{a}] \mathrm{P}$ showed no significant increase of mutagenic or cytotoxic intermediates. In another study the effects of $\mathrm{B}[\mathrm{a}] \mathrm{P}, \mathrm{B}[\mathrm{e}] \mathrm{P}, \mathrm{DMBA}$ and 3-methylcholanthrene on atherosclerotic plaque development in White Carrieau pigeons was investigated. ${ }^{75}$ With the exception of $\mathrm{B}[\mathrm{e}] \mathrm{P}$, the investigated $\mathrm{PAHs}$ were potent initiators and promotors of the atherogenic process. Again, no effects of the PAH treatment on confounding parameters, like blood pressure or plasma lipid levels, were seen. 
Finally, laboratory rodents were used to prove the involvement of PAHs in atherosclerosis. Results from a study with $A h$-responsive and $A b$-nonresponsine mice showed that the number and size of the atherosclerotic lesions were larger in all the PAH exposed animals, but that the effects were most profound in the $A h$ responsive mice. ${ }^{76}$ Studies in which the exposure of sidestream cigarette smoke was investigated revealed high levels of DNA damage in the aorta of rats.77,78 In the most recent studies, exposure of apoE-KO mice to sidestream cigarette smoke resulted in high levels of aortic mitochondrial DNA damage, larger atherosclerotic plaques and increased aortic levels of esterified and unesterified cholesterol, while serum cholesterol levels and cellular plaque composition were unchanged. ${ }^{79,80}$

\section{In vitro studies}

From the above, it is clear that the animal studies showed the involvement of PAHs in the development of atherosclerosis. The main goal of $i$ vitro experiments was to get more insight in the underlying mechanisms and the genes and enzymes involved in chemical atherogenesis (Table 1.2). Several studies have focussed on mechanisms involved in SMC proliferation, since the development of atherosclerosis is characterized by an abnormal proliferation of SMCs. Bond $e t$ al. ${ }^{81}$ were the first to publish in vitro data on the metabolism of PAHs in human aortic smooth muscle cells. They suggested that mutations in SMCs might be involved in the abnormal proliferation of these cells. As evidence supporting their idea, they showed that SMCs are able to metabolize $\mathrm{B}[\mathrm{a}] \mathrm{P}$ and $\mathrm{DMBA}$ via monooxygenases, and that this metabolism can be induced by 1,2-benz[a]anthracene. The main metabolites of $\mathrm{B}[\mathrm{a}] \mathrm{P}$ appeared to be phenols, whereas DMBA metabolism resulted in hydroxylation metabolites, which were all hydroxylated at methyl carbon 7 and 12. In line with the idea that PAHs have to be metabolized to enhance SMC proliferation, the role of arylhydrocarbonhydroxylase $(\mathrm{AHH})$, a necessary $\mathrm{PAH}$ metabolizing enzyme, was investigated. The activity of AHH, a PAH-inducible enzyme, was found to be higher in atherosclerosis-susceptible species. Stavenow et at. ${ }^{22}$ showed that DMBA increased SMC proliferation in wim. However, in a second study by the same investigators it was shown that DMBA was not capable of inducing $\mathrm{AHH}$ in rabbit and bovine SMCs, suggesting that probably anorher mechanism is responsible for the DMBA-induced SMC proliferation. ${ }^{83}$ These results contradict with a study of Moorthy of al. ${ }^{24}$ who found inducible levels of AHH activity and subsequently higher DNA adduct levels in SMCs after exposure to 3-methylcholanthrene. Along the line of PAH metabolism and DNA damage, upregulation of proto-oncogenes like $c-m y z$ and $f-H a-r a s$ and the possible disruption of the APC gene in SMCs exposed to B[a]P were reported ${ }^{85-87}$ Furthermore, direct 
Table 1.2 In vitro studies suggesting the involvement of environmental PAHs in atherogenesis.

\begin{tabular}{|c|c|c|c|c|}
\hline Ref. & Cells & PAHs & Outcome & Remarks \\
\hline 81 & $\begin{array}{l}\text { Human fetal } \\
\text { SMCs }\end{array}$ & DMBA, B[a]P & $\begin{array}{l}\text { DMBA and B[a]P merabolized via monooxygenases into } \mathrm{B}[\mathrm{a}] \mathrm{P} \text {-derived phenols } \\
\text { and DMBA hydroxylation products. }\end{array}$ & $\begin{array}{l}\text { Enhancement of metabolism by pre- } \\
\text { incubation with } 1,2 \text {-benz[a]anthracene. }\end{array}$ \\
\hline 90 & $\begin{array}{l}\text { Human and rat } \\
\text { SMCs }\end{array}$ & $\begin{array}{l}\text { Cigarette } \\
\text { smoke }\end{array}$ & $\begin{array}{l}\text { Dose-dependent inhibition of intercellular communication up to } 60 \% \text { by } \\
\text { cigarette smoke condensate. }\end{array}$ & \\
\hline 82,83 & $\begin{array}{l}\text { Rabbir and } \\
\text { bovine SMCs }\end{array}$ & DMBA & $\begin{array}{l}\text { Increased proliferation and viability after PAH exposure. No basal or inducible } \\
\text { AHH activity. Possible role ornithine decarboxylase?? }\end{array}$ & $\begin{array}{l}\text { Q-naphoflavone inhibits cell } \\
\text { proliferation. }\end{array}$ \\
\hline 85 & Rat SMCs & $\mathrm{B}[\mathrm{a} \mid \mathrm{P}$ & $\begin{array}{l}\mathrm{B}[\text { a]P induced expression levels of proto-oncogenes c-myc and c-Ha-ras in rat } \\
\text { aortic smooth muscle cells. }\end{array}$ & \\
\hline 91,92 & vSMCs & $\mathrm{B}[\mathrm{a}] \mathrm{P}$ & $\begin{array}{l}\text { First delay cell cycle progression and proliferation, then higher proliferation. } \\
\text { B[a]P inhibits protein kinase } C \text {-mediated phosphorylation of exogenous and } \\
\text { endogenous proteins. }\end{array}$ & \\
\hline 88 & vSMCs & $\begin{array}{l}\text { Cigarette } \\
\text { smoke }\end{array}$ & $\begin{array}{l}\text { Decreased activity of SOD, catalase and glusathione peroxidase. Enhanced } \\
\text { mitogenic effect response of hydrogen peroxides. }\end{array}$ & \\
\hline 86 & vSMCs & $\mathrm{B}|\mathrm{a}| \mathrm{P}$ & $\begin{array}{l}\text { B[a]P modulates vSMCs from quiescent to proliferative state together with } \\
\text { activation of L.MA retrotransposon. Increased unscheduled DNA synthesis, } \\
\text { inhibition DNA repair capacity. }\end{array}$ & $\begin{array}{l}\text { No insertional mutations in p } 53 \text { or RB } \\
\text { genes. }\end{array}$ \\
\hline 89 & $\begin{array}{l}\text { Human and rat } \\
\text { vSMCs }\end{array}$ & $\mathrm{B}[\mathrm{a}] \mathrm{P}$ & $\begin{array}{l}\text { Time and dose dependent increase in } \mathrm{COX}_{2} \text {. Increased binding of NF-KB to } \\
\text { DNA after } \mathrm{B}[\mathrm{a}] \mathrm{P} \text { exposure. }\end{array}$ & $\begin{array}{l}\text { NAC suppresses } B[a] P \text {-mediated } \\
\text { induction of } \mathrm{COX}_{3}\end{array}$ \\
\hline
\end{tabular}


Table 1.2 (Continued) In vitro studies suggesting the involvement of environmental PAHs in atherogenesis.

\begin{tabular}{|c|c|c|c|c|}
\hline Ref. & Cells & PAHs & Outcome & Remarks \\
\hline 87 & Mouse vSMCs & $\mathrm{B}[\mathrm{a}] \mathrm{P}$ & $\mathrm{B}[\mathrm{a}] \mathrm{P}$ increased c-Ha-ras mRNA levels in a redox-sensitive manner. & $\begin{array}{l}\text { NAC inhibits } \mathrm{B}|\mathrm{a}| \mathrm{P} \text {-induced } \mathrm{c}-\mathrm{Ha} \text {-ras } \\
\text { levels. }\end{array}$ \\
\hline 93 & HUVEC & $\mathrm{B}[\mathrm{a}] \mathrm{P}$ & $\begin{array}{l}\text { Increased DNA damage in B[a]P-exposed cells. Damage even higher after } \\
\text { induction of Ah-receptor. }\end{array}$ & $\begin{array}{l}\text { B-naphtoflarone as Ah-receptor } \\
\text { agonist. }\end{array}$ \\
\hline 94 & $\begin{array}{l}\text { Primair } \\
\text { endorhelial cells, } \\
\text { monocytes }\end{array}$ & $\begin{array}{l}B[a] P, \text { tobacco } \\
\text { smoke }\end{array}$ & $\begin{array}{l}\text { Tobacco smoke but not } \mathrm{B}[\mathrm{a}] \mathrm{P} \text { induced heat shock protein } 70 \text { and heme } \\
\text { oxygenase-1, loss of mitochondral membrane potential. Both treatments } \\
\text { induced necrosis. }\end{array}$ & $\begin{array}{l}\text { Prevention of toxic effects by } \\
\text { antioxidant NAC. }\end{array}$ \\
\hline 84 & $\begin{array}{l}\text { Mouse aortic } \\
\text { SMCs }\end{array}$ & $3-\mathrm{MC}$ & Inducibel $\mathrm{AHH}$ activity. Multiple DNA adducts after exposure to $3-\mathrm{MC}$. & $\begin{array}{l}\text { Induction of CYP1B1 but not } \\
\text { CYP1A1. }\end{array}$ \\
\hline 95 & HUVEC & $\begin{array}{l}\text { Tobacco } \\
\text { smoke }\end{array}$ & Reduction of cell viability via necrosis. & NAC and statins inhibit adverse effects. \\
\hline
\end{tabular}


and indirect evidence showed the induction of ROS formation and disturbance of the oxidant-antioxidant balance in SMCs exposed to PAHs. ${ }^{88,89}$

A pathway that does not immediately requires PAH metabolism, is the disruption of cell communication. Intercellular communication by gap junctions is an important aspect of regulating growth and differentiation. It was proven that tobacco smoke condensate could dose-dependently reduce the gap junction communication of human SMCs up to $60 \%{ }^{90}$ Together with these findings it was proven that protein kinase $\mathrm{C}$, also important in the regulation of cell proliferation could be inhibited by $\mathrm{B}[\mathrm{a}] \mathrm{P}$ exposure. ${ }^{91,92}$ Overall, various aspects of $\mathrm{PAH}$-induced disturbed SMC metabolism have been investigated. All studies agree that PAHs induce uncontrolled SMC proliferation.

Although SMC proliferation is an important feature in atherosclerosis, the first step of the disease is formed by endothelial dysfunction. Human vascular endothelial cells (HUVEC) exposed to B[a]P showed an increase in DNA damage associated with the expression of the Ah-receptor. ${ }^{93}$ Two other studies showed that $\mathrm{B}[\mathrm{a}] \mathrm{P}$ or tobacco smoke exposure resulted in increased cell necrosis. ${ }^{94,95}$ This necrosis could be inhibited by the antioxidant $\mathrm{N}$-acetylcysteine. Another important player in the development of atherosclerotic plaques is the monocyte/macrophage. It was shown that B[a]P exposure had a profound inhibitory effect on differentiation of human blood monocytes into macrophages. In addition, a reduced expression of macrophagic phenotype markers such as CD71 and CD64 were seen. $\mathrm{B}[\mathrm{a}] \mathrm{P}$ exposure had no effects on cell viability. ${ }^{96}$ Furthermore, it was shown that PAH exposure induces oxidative stress in human and murine macrophage cell lines. This oxidative stress leads to the activation of stressactivated protein kinases. ${ }^{77}$ However, the relation between these PAH-induced changes in macrophage metabolism and atherosclerosis remains to be investigated.

\section{Human studies}

Nearly all the evidence for the involvement of PAH exposure in the development of atherosclerosis in humans can be brought back to one of the most important risk factors of this disease: cigarette smoking. Since cigarette smoke contains over 1000 potentially harmful chemicals, including $\mathrm{PAH}$, it is not possible to ascribe the atherogenic effects merely to the exposure of PAHs. Still, human data linking active and passive cigarette smoking to atherosclerotic cardiovascular disease are overwhelming. ${ }^{98-105}$ Furthermore, several studies have shown that cigarette smoking is not related to other risk factors of atherosclerosis like body mass index, serum cholesterol levels, blood sugar levels, hypertension and alcohol consumption.98-100 Only one study suggested a synergistic effect of smoking and the apoE allele $E 4 . .^{102}$ More direct evidence for the involvement of PAHs in the 
development of human atherosclerosis was provided by the group of De Flora ${ }^{106,107}$ who showed the presence of BPDE-DNA adducts in the smooth muscle layer of atherosclerotic lesions. These data correlated with the smoking status of the patients. Using a less sensitive technique which measures not merely PAH-DNA adducts, but bulky adducts in general, Binkova et al. ${ }^{108,109}$ showed that DNA adduct levels were higher in subjects with frequent atherosclerotic changes compared to subjects with few atherosclerotic changes.

Although the presented human data are circumstantial they, at the least, suggest a role of PAH exposure in the development of atherosclerosis.

\section{Aim and outline of this thesis}

\section{Aim of this thesis}

When Benditt and Benditt postulated their monoclonal theory, ${ }^{17}$ they opened a new area of cardiovascular research: the chemical atherogenesis. Ever since, numerous in vitro and in vivo studies have linked PAH exposure to the development of atherosclerosis. PAHs have proven to progress atherosclerotic plaque progression in several animal models. 65.76 Even an initiating effect of PAHs on plaque development has been described. ${ }^{71,75,81}$ Human data have linked the PAHinduced DNA damage to the progression of atherosclerosis. ${ }^{106,108,110}$ Subsequent, in vitro studies have shown that PAHs induce SMC progression, loss of endothelial function, and inhibit monocyte differentiation. But still the prove that PAHs induce atherosclerosis via local DNA damaging events is lacking.

In this thesis, we tested the main hypothesis that PAHs modulate atherosclerotic plaque development by DNA damaging events in the arterial vessel wall (Figure 1.5).

Our first working hypothesis is that the aorta is a target organ for the direct $(\mathbb{B}[\mathrm{a}] \mathrm{P}$ DNA adducts) and indirect (etheno-DNA adducts) DNA damaging effects of B[a]P. Furthermore, we hypothesize that the formation and distribution of these B[a]P-DNA adducts is affected by dietary-induced changes in plasma lipid levels, and that chronic exposure to $\mathrm{B}[\mathrm{a}] \mathrm{P}$, but not $\mathrm{B}[\mathrm{e}] \mathrm{P}$, the non-DNA damaging structural isomer of $\mathrm{B}[\mathrm{a}] \mathrm{P}$, will affect atherosclerotic plaque development in apoE$\mathrm{KO}$ mice. 


\section{Polycyclic aromatic hydrocarbon}<smiles>c1ccc2c(c1)cc1ccc3cccc4ccc2c1c34</smiles>

Reactive metabolites
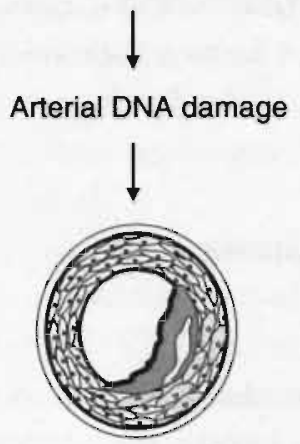

Atherosclerosis

Figure 1.5 Schematic overview of the hypothesis that PAHs modulate the process of atherosclerosis via DNA damaging events in the vessel wall.

\section{Outline of this thesis}

In the current thesis we first examined the distribution of $\mathrm{B}[\mathrm{a}] \mathrm{P}$-induced DNA damage over several putative target organs of two mouse models for atherosclerosis, the apoE*3-Leiden mouse model and the apoE-knockout (apoEKO) mouse, by means of $32 \mathrm{P}$-postlabeling. Furthermore, the effect of diet modulated plasma lipid levels on the levels of $B[a] P=D N A$ adducts in different organs, were studied in both mouse strains (Chapter 2) In Chapter 3 we focussed on B[a]P-induced oxidative DNA damage by measuring etheno-DNA adducts in the aorta of apoE-KO mice. In Chapter 4, the effects of chronic B[a]P exposure are described on atherosclerotic plaque development and phenorype in apoE-KO mice. Subsequently, in Chapter 5 the role of DNA adducts in atherosclerotic plaque development was studied by comparing atherosclerotic plaque development and phenotype in apoE-KO mice, chronically exposed to the adduct forming B[a] its structurally related non-adduct forming isomer B[e]P. In Chapter 6, the PAHrelated inflammatory plaque phenotype was further investigated by measuring gene expression levels of some inflammatory genes (TGF $\beta$, TNF $\alpha$, Il- 6 , and MCP1) in arterial tissue of acutely exposed apoE-KO mice. In Chapter 7 the findings and limitations of the studies described above are discussed and possible future directions are given. 


\section{References}

1. Virmani R, Kolodgie FD, Burke AP, Farb A, Schwartz SM: Lessons from sudden coronary death: a comprehensive morphological classification scheme for atherosclerotic lesions. Arterioscler Thromb V asc Biol 2000, 20:1262-1275

2. Koek HL, Van Leest LATM, Verschuren WMM, Bots ML: Hart- en vaatziekten in Nederland 2003, cijfers over leefstijl- en risicofactoren, ziekte en sterfte. Den Haag, Nederlandse Hartstichting, 2003, pp 7-19

3. Marchand FJ: Uber arteriosclerose (atherosclerose). Presented at the Kongresse fur Innere Medizin, 1904

4. Tegos T], Kalodiki E, Sabetai MM, Nicolaides AN: The genesis of atherosclerosis and risk factors: a review. Angiology 2001, 52:89-98

5. Munro JM, Cotran RS: The pathogenesis of atherosclerosis: atherogenesis and inflammation. Lab Invest 1988, 58:249-261

6. Worthley SG, Osende JI, Helft G, Badimon JJ, Fuster V: Coronary artery disease: pathogenesis and acute coronary syndromes. Mt Sinai J Med 2001, 68:167-181

Ross R: Atherosclerosis-an inflammatory disease. N Engl/ Med 1999, 340:115-126

8. Lusis AJ: Atherosclerosis. Nature 2000, 407:233-241

9. Stary HC: Natural history and histological classification of atherosclerotic lesions: an update [comment]. Arterioscter Thromb Vasc Biol 2000, 20:1177-1178

10. Stary H, Blankenhorn D, Chandler A, Glagov S, Insull W, Richardson M, Rosenfeld M, Schaffer S, Schwartz C, Wagner W, Wissler R: A definition of initial, fatty streak, and intermediate lesions of atherosclerosis. Arteriosclerosis and thrombosis 1994, 14:841-856

11. Stary H, Blankenhorn D, Chandler A, Glagov S, Insull W, Richardson M, Rosenfeld M, Schaffer S, Schwartz C, Wagner W, Wissler R: A definition of advanced types of atherosclerotic lesions and a histological classification of atherosclerosis. Arteriosclerosis, thrombosis and vascular biology 1995, 15:1513-1531

12. Libby P: Molecular bases of the acute coronary syndromes. Circulation 1995, 91:2844-2850

13. Virchow R: Phlogose und thrombose im gefassystem. Gesammelte Abhandlungen zur Wissenschaftichen Medicin. Berlin, Meidinger Sohn and Co, 1856, pp 458-463

14. Ross R, Glomset JA: Atherosclerosis and the arterial smooth muscle cell: Proliferation of smooth muscle is a key event in the genesis of the lesions of atherosclerosis. Science 1973, 180:1332-1339

15. Ross R: The pathogenesis of atherosclerosis: a perspective for the 1000s. Nature 1993, 362:801-809

16. Ross R: The pathogenesis of atherosclerosis-an updare. N Eng/J Med 1986, 314:488-500

17. Benditr E.P, Benditt JM: Evidence for a monoclonal origin of human atherosclerotic plaques. Proc Natl Acad So U S A 1973, 70:1753-1756́

18. Lyon MF: Some milestones in the history of X-chromosome inactivation. Annu Rev Genet $109) 2,26: 16,28$

19. Linder D, Garter SM: Glucose-6-phosphate dehydtogenase mosaicism: utilization as a cell marker in the study of leiomyomas. Sitme 1965, 150:67-69

20. Pearson TA, Dillman JM, Solex K. Heprinstall R.H: Clonal markers in the study of the origin and growth of human atherosclerotic lesions. Cin Res i978, 43:10-18

21. Thomas WA, Reiner JM, Janakidevi K. Florentin RA, Lee KT: Population dynamies of atterial cells during atherogenesis. X. Study of monotypism in atherosclerotic lesions of black women hererozygous for glucose-6-phosphate dehydrogenase (G-6-PD). Exp Mof Patbo/ 1979, 31:367-386

22. Pearson TA, Dillman JM, Heprinstall RH: Clonal mapping of the human aorta. Relationship of monoclonal characteristics, lesion thickness, and age in normal intima and atherosclerotic lesions. Am J Patbo/ 1987. 126:33-39

23. Poolc JC: The monocional theory of atherosclerosis. Br j Clin Pract 1978, 32:219-223 
24. Stemme S, Rymo L, Hansson GK: Polyclonal origin of $T$ lymphocytes in human atherosclerotic plaques. Lab Invest 1991, 65:654-660

25. Murry CE, Gipaya CT, Bartosek T, Benditt EP, Schwartz SM: Monoclonality of smooth muscle cells in human atherosclerosis. Am / Pathol 1997, 151:697-705

26. Chung IM, Schwartz SM, Murry CE: Clonal architecture of normal and atherosclerotic aorta: implications for atherogenesis and vascular development. Am J Patho/ 1998, 152:913923

27. Schwartz SM, Murry CE: Proliferation and the monoclonal origins of atherosclerotic lesions. Annu Rev Med 1998, 49:437-460

28. Bennett MR, Littlewood TD, Schwartz SM, Weissberg PL: Increased sensitivity of human vascular smooth muscle cells from atherosclerotic plaques to p53-mediated apoptosis. Cim Res 1997, 81:591-599

29. Daugherty A: Mouse models of atherosclerosis. Am J Med Sci 2002, 323:3-10

30. Fazio S, Linton MF: Mouse models of hyperlipidemia and atherosclerosis. Front Biosci 2001, 6:D515-525

31. Piedrahita JA, Zhang SH, Hagaman JR, Oliver PM, Maeda N: Generation of mice carrying a mutant apolipoprotein $\mathrm{E}$ gene inactivated by gene targeting in embryonic stem cells. Proc Natl Acad Sri U S A 1992, 89:4471-4475

32. Plump AS, Smith JD, Hayek T, Aalto-Setala K, Walsh A, Verstuyft JG, Rubin EM, Breslow JL: Severe hypercholesterolemia and arherosclerosis in apolipoprotein E- deficient mice created by homologous recombination in ES cells. Cell 1992, 71:343-353

33. van den Maagdenberg AM, Hofker MH, Krimpenfort PJ, de Bruijn I, van Vlijmen B, van der Boom H, Havekes LM, Frants RR: Transgenic mice carrying the apolipoprotein E3. Leiden gene exhibit hyperlipoproteinemia. J Biol Chem 1993, 268:10540-10545

34. Groot PH, van Vlijmen BJ, Benson GM, Hofker MH, Schiffelers R, Vidgeon-Hart M, Havekes LM: Quantitative assessment of aortic atherosclerosis in APOE*3 Leiden transgenic mice and its relationship to serum cholesterol exposure. Arterioseler Thromb V ase Biol 1996, 16:926-933

35. Penn A: Molecular alterations critical to the development of arteriosclerotic piaques: a role for environmental agents. Emuiron Health Perspect 1989, 81:189-192

36. Hall M, Grover PL: Polycyclic aromatic hydrocarbons: metabolism, activation and tumour initiation. Chemical carcinogenesis and mutagenesis. Edited by Cooper CS, Grover PL. New York, Raven Press, 1990, pp 327-372

37. Gelboin HV: Benzo|alpha|pyrene metabolism, activarion and carcinogenesis: role and regulation of mixed-funcrion oxidases and related enzymes. Plysio/ Rev 1980, 60:1107-1166

38. Polynuclear aromatic compounds, Part 1, Chemical, environmental and experimental data. LARC Monogr Eval Caminog Risk Chem Hum 1983, 32:1-453

39. Mackenzie KM, Angevine DM: Inferriliry in mice exposed in uicro to benzo(a)pyrene. Bial Reprod 1981, 24:183-191

40. Urso P, Gengozian N: Depressed humoral immunity and increased numor incidence in mice following in utero exposure to benzo[alphalpyrene. J Toxicol Emvinon Heatth 1980, $6: 569-576$

41. Conney AH: Induction of microsomal enzymes by foreign chemicals and carcinogenesis by polycyclic aromatic hydrocarbons: G. H. A. Clowes Memorial Lecture. Cancer Res 1982 , 42:4875-4917

42. Hankinson O: The aryl hydrocarbon receptor complex. Anmu Rer Pharmacol Toxicol 1995, $35: 307-340$

43. Kim KB, Lee BM: Oxidative stress to DNA, protein, and antioxidant enzymes (superoxide dismutase and catalase) in rats treated with benzo(a)pyrenc. Cancr Lett 1997, 113:205-212.

44. Grimmer G, Stober W. Jacob J, Mohr U, Schoene K, Brune H, Misfeld J: Inventory and biological impact of polycyclic carcinogens in the environment. Exp Patho/ 1983, 24:3-13

45. Miller KP, Ramos KS: Impact of cellular metabolism on the biological effects of benzo|alpyrenc and related hydrocarbons. Drug Metab Rev 2001, 33:1-35 
46. Kim PM, DeBoni U, Wells PG: Peroxidase-dependent bioactivation and oxidation of DNA and protein in benzo[alpyrene-initiated micronucleus formation. Free Radic Biol Med. $1997,23: 579-596$

47. el Ghissassi F, Barbin A, Nair J, Bartsch H: Formation of 1,N6-ethenoadenine and 3,N4 ethenocytosine by lipid peroxidation products and nucleic acid bases. Chem Res Toxiool $1995,8: 278-283$

48. Gram TE: Chemically reactive intermediates and pulmonary xenobiotic toxicity. Pharmacol $\operatorname{Re} 1997,49: 297-341$

49. Pfeifer GP, Denissenko MF: Formation and repair of DNA lesions in the p53 gene: relation to cancer mutations? Environ Mo/ Mulagen 1998, 31:197-205

50. Ko LJ, Prives C: p53: puzzle and paradigm. Genes Dev 1996, 10:1054-1072

51. Jelinsky SA, Liu T, Geacintov NE, Loechler EL: The major, N2-Gua adduct of the (+)anti-benzo[a|pyrene diol epoxide is capable of inducing $\mathrm{G}->\mathrm{A}$ and $\mathrm{G}->\mathrm{C}$, in addition to G->T, mutations. Biochemistry 1995, 34:13545-13553

52. Ruggeri B, DiRado M, Zhang SY, Bauer B, Goodrow T, Klein-Szanto A]: Benzolalpyreneinduced murine skin tumors exhibit frequent and characteristic $G$ to $T$ mutations in the p53 gene. Proc Natl Acad Sci U S A 1993, 90:1013-1017

53. Denissenko MF, Pao A, Tang M, Pfeifer GP: Preferential formation of benzolajpyrene adducts at lung cancer mutational hotspots in P53. Science 1996, 274:430-432

54. Guevara NV, Kim HS, Antonova EI, Chan L: The absence of p53 accelerates, atherosclerosis by increasing cell proliferation in vivo. Nat Med 1999, 5:335-339

55. iacopetta B, Wysocki S, Norman P. House A: The p53 tumour suppressor gene is overexpressed but not mutated in human atherosclerotic tissue. international journal of oncology $1995,7: 399-402$

56. Pollutants CotBEoA: Particulate Polycyclic Organic Matter. Washington, National Academy of Science, 1972

57. Wood AW, Levin W, Thakker DR, Yagi H, Chang RI, Ryan DE, Thomas PE, Dansette PM, Whittaker N, Turujman S, Lehr RE, Kumar S, Jerina DM, Conney AH: Biological activity of benzo[elpyrene. An assessment based on mutagenic activities and metabolic profiles of the polycyclic hydrocarbon and its derivatives. J Biol Chem 1979, 254:4408-4415

58. Dipple A: Polynuclear aromatic carcinogens. Chemical carcinogens ACS monograph series. Edited by Searle CE. Washington D.C., American Chemical Society, 1976, pp 245-31.4

59. Buening MK, Wislocki PG, Levin W, Yagi H, Thakker DR, Akagi H, Koreeda M, Jerina DM. Conncy AH: Tumorigenicity of the optical enanuomers of the diastereomeric benzo|a|pyrenc 7,8-diol-9.10-cpoxides in nevborn mice: exceptional activiry of $(+)$ 7beta,8alpha-dihydroxy-9alpha,10alpha-epoxy-7,8,9.10-emahydobenzofalpyrenc. Proc Natt Arad Sci USA 1978, 75:5358-5361

60. Slaga TJ, Gleasen GL, Mills G, Ewald L, Fu PP, Lee HM, Harvey RRG: Comparison of the skin mimor-initiating accivities of dihydrodiols and dial-epoxides of varions polycyclic aromatic hydrocarbons. Cancer Res 19BO, 40:1081-1984

61. Wood AW, Chang RL, Huang MT, Levin W, Lehr RE, Kumar S, Thakker DR, Yagi H, Jerina DM, Conncy AH: Mutagenicity of benzo(c)pyrenc and triphenylene retrahydrocpoxides and diol-epoxides in bacterial and mammalian cells. Cancer Res 1980 , 40:1985-1989

62. Thakker DR, Levin W, Buening M, Yagi H, Lehr RE, Wood AW, Conney AH, Jerina DM: Species-specific enhancement by 7.8-benzoflavone of hepatic microsomal metabolism of benzo[e]pyrene 9,10-dihydrodiol to bay-region diol cpoxides. Cancer Res 1981, 41:13891396

63. Albert RE, Vanderlaan M, Burns F. Nishizumi M: Effect of carcinogens on chicken atherosclerosis. Canor Res 1977, 37:2232-2235

64. Batastini G, Penn A: An ultrastructural comparison of carcinogen-associated and spontaneous aorric lesions in the cockerel. Am J Pathol 1984, 114:403-409 
65. Penn A, Batastini G, Soloman J, Burns F, Albert R: Dose-dependent size increases of aortic lesions following chronic exposure to 7,12-dimethylbenz(a)anthracene. Camcer Res $1981,41: 588-592$

66. Penn AL, Batastini GG, Albert RE: Age-dependent changes in prevalence, size and proliferation of arterial lesions in cockerels. II. Carcinogen-associated lesions. Artery 1981, 9:382-393

67. Penn A, Snyder CA: Inhalation of sidestream cigaretie smoke accelerates development of arteriosclerotic plaques. Circulation 1993, 88:1820-1825

68. Penn A, Keller K, Snyder C, Nadas A, Chen LC: The tar fraction of cigarette smoke does not promote arteriosclerotic plaque development. Environ Health Perspect 1996, 104:11081113

69. Bond JA, Yang HY, Majesky MW, Benditt EP, Juchau MR: Metabolism of benzo[alpyrene and 7,12-dimethylbenz[a]anthracene in chicken aortas: monooxygenation, bioactivation to mutagens, and covalent binding to DNA in vitro. Toxicol App/ Pharmacol 1980, 52:323-335

70. Bond JA, Gown AM, Yang HL, Benditt EP, Juchau MR: Further investigations of the capacity of polynuclear aromatic hydrocarbons to elicit atherosclerotic lesions. J Toxicol Envinon Healtb 1981, 7:327-335

71. Majesky MW, Reidy MA, Benditt EP, Juchau MR: Focal smooth muscle proliferation in the aortic intima produced by an initiation-promotion sequence. Proc Natl Acad $S_{a}$ U S A $1985,82: 3450-3454$

72. Penn A, Hubbard FC, Jr., Parkes JL: Transforming potential is detectable in arteriosclerotic plaques of young animals. Arterioster Thromb 1991, 11:1053-1058

73. Penn A, Snyder C: Arteriosclerotic plaque development is 'promoted' by polynuclear aromatic hydrocarbons. Carcinogenesis 1988, 9:2185-2189

74. Majesky MW, Yang HY, Benditt EP, Juchau MR: Carcinogenesis and atherogenesis: differences in monooxygenase inducibility and bioactivation of benzo[a]pyrene in aortic and hepatic tissues of atherosclerosis-susceptible versus resistant pigeons. Carinogenesis $1983,4: 647-652$

75. Revis NW, Bull R, Laurie D, Schiller CA: The effectiveness of chemical carcinogens to induce atherosclerosis in the white Carneau pigeon. Toxicology 1984, 32:215-227

76. Paigen B, Holmes PA, Morrow A, Mitchell D: Effect of 3-methylcholanthrene on atherosclerosis in two congenic strains of mice with different suscepribilities to methylcholanthrene-induced tumors. Cancer Res 1986, 46:3321-3324

77. Izzotti A, D'Agostini F, Bagnasco M, Scatolini L, Rovida A, Balansky RM, Cesaroné CF, De Flora S: Chemoprevention of carcinogen-DNA adducts and chronic degenerative diseases. Cancer Res 1994. 54:1994s-1908s

78. Izzorti A, Camoirano A, Cariglia C. Tampa E, De Flora S: Formation of DNA adducts in the aorta of smoke-exposed rats, and modulation by chemopreventive agents. Mutat Res 2001, 494:97-106

79. Gairola CG, Drawdy MiI, Block AE, Daugherty A: Sidestream cigarette smoke accelerates atherogenesis in apolipoprotein E-/- mice. Atherosclerosis 2001, 156:49-55

80. Knight-Lozano $\mathrm{CA}$, Young CG, Burow DL, Hu ZY, Uyeminami D. Pinkertoñ KE, Ischiropoulos H, Ballinger SW: Cigaretue smoke exposure and hypercholesterolemia increase mitochondrial damage in cardiovascular tissues. Circulation 2002, 105:849-854

81. Bond JA, Kocan RM, Benditi EP, Juchau MR: Metabolism of benzo[a]pyrene and 7,12. dimethylbenz|ajanthracene in cultured human fetal aortic smooth muscle cells. Life Sa $1979,25: 425-430$

82. Stavenow L, Pessah-Rasmussen H: Effects of polycyclic aromatic hydrocarbons on proliferation, collagen secreion and viability of arterial smooth muscle cells in culture. Artery 1988, 15:94-108

83. Pessah-Rasmussen H, Stavenow I. Xu CB, Berglund A: Increased smooth miscle cell proliferation by dimethylbenzanthracene is correlated to variations in activity of ornithine decarboxylase but not-arylhydrocarbonhydroxylase. Artery 1991, 18:240-255 
84. Moorthy B, Miller K.P, Jiang W, Ramos KS: The atherogen 3-methylcholanthrene induces multiple DNA adducts in mouse aortic smooth muscle cells: role of cytochrome P4501B1. Cardionase Res 2002, 53:1002-1009

85. Sadhu DN, Merchant M, Safe SH, Ramos KS: Modulation of protooncogene expression in rat aortic smooth muscle cells by benzo[a]pyrene. Arch Biochem Biopbys 1993, 300:124-131

86. Lu KP, Hallberg LM, Tomlinson J, Ramos KS: Benzo(a)pyrene activates L.MMd retrotransposon and inhibits DNA repair in vascular smooth muscle cells. Mutat Res 2000, 454:35-44

87. Kerzee JK, Ramos KS: Activation of c-Ha-ras by benzo(a)pyrene in vascular smooth muscle cells involves redox stress and aryl hydrocarbon receptor. Mol Pharmaco/ 2000, $58: 152-158$

88. Nishio E, Watanabe Y: Cigarette smoke extract is a modulator of mitogenic action in vascular smooth muscle cells. $L$ ife $S a i$ 1998, 62:1339-1347

89. Yan Z, Subbaramaiah K, Camilli T, Zhang F, Tanabe T, McCaffrey TA, Dannenberg AJ, Weksler BB: Benzo|a|pyrene induces the transcription of cyclooxygenase-2 in vascular smooth muscle cells. Evidence for the involvement of extracellular signal-regulared kinase and NF-kappaB. J Biol Chem 2000, 275:4949-4955.

90. Zwijsen RM, de Haan LH, Oosting JS, Pekelharing HL, Koeman JH: Inhibition of intercellular communication in smooth muscle cells of humans and rats by low density lipoprotein, cigarette smoke condensate and TPA. Atherositerosis 1990, 85:71-80

91. Ou X, Ramos KS: Benzo[a]pyrene inhibits protein kinase $\mathrm{C}$ activity in subcultured rat aortic smooth muscle cells. Chem Biol Interact 1994, 93:29-40.

92. Ou X, Weber TJ, Chapkin RS, Ramos KS: Interference with protein kinase C-related signal transduction in vascular smooth muscle cells by benzo[a]pyrene. Anb Biocbem Bioplys 1995, 318:122-130.

93. Annas A, Brittebo E, Hellman B: Evaluation of benzo|a|pyrene-induced DNA damage in human endothelial cells using alkaline single cell gel electrophoresis. Mutat Res 2000, 471:145-155

94. Vayssier-Taussat M, Camilli T, Aron Y, Meplan C, Hainaut P, Polla BS, Weksler B: Effects of tobacco smoke and benzo[a]pyrene on human endothelial cell and monocyte stress responses. Am ] Pbysiol Heart Cirr Physiol 2001, 280:H1293-1300

95. Bernhard D, Pfister G, Huck CW, Kind M, Salvenmoser W, Bonn GK, Wick G: Disruption of vascular endothelial homeostasis by tobacco smoke-impact on atherosclerosis. Faseb J 2003

96. van Grevenynghe J. Rion S, Le Ferrec E, Le Vee M, Amiot L, Fatuchet R, Fardel O: Polycyclic aromatic hydrocarbons inhibit differentiation of human monocyses into macrophages. J Immunol 2003, 170:2374-2381

97. Ng D, Kokot N, Hiura T, Faris M, Saxon A, Nel A: Macrophage activation by polycyclic aromatic hydrocarbons: evidence for the involvement of stress-activated protein kinases, activator protein-1, and antioxidant response elements. J Immunol 1998, 161:942-951

98. Inoue $\mathrm{T}$, Oku K, Kimoto K, Takao M, Nomoto J. Handa K, Kono S, Arakawa K: Relationship of cigaretre smoking to the severity of coronary and thoracic aortic atherosclerosis. Cardiology 1995, 86:374-379

99. Sempos CT, Durazo-Arvizu R, McGee DL, Cooper RS, Prewitt TE: The influence of cigaretre smoking on the association between body weight and mortaliry. The Framingham Heart Study revisited. Ann Epidemiol 1998, 8:289-300.

100. Jee SH, Suh I, Kim IS, Appel LJ: Smoking and atherosclerotic cardiovascular disease in men with low levels of serum cholesterol: the Korea Medical Insurance Corporation Study. Jama 1999, 282:2149-2155.

101. Winkelmann BK, Boehm BO, Nauck M, Kleist P, Marz W, Verho NK, Ranjith N, Kneissl G: Cigarette smoking is independently associated with markers of endothelial dysfunction and hyperinsulinaemia in nondiabetic individuals with coronary artery disease. Curr Med Ries Opin 2001, 17:132-141 
102. Djousse L, Myers RH, Province MA, Hunt SC, Eckfeldt JH, Evans G, Peacock JM, Ellison RC: Influence of apolipoprotein E, smoking, and alcohol intake on carotid arherosclerosis: National Heart, Lung, and Blood Institute Family Heart Study. Stroke 2002, 33:1357-1361

103. Howard G, Burke GL, Szklo M, Teli GS, Eckfeldt J, Evans G, Heiss G: Active and passive smoking are associated with increased carotid wall thickness. The Atherosclerosis Risk in Communities Study. Anb Intern Med 1994, 154:1277-1282

104. Glantz SA, Parmley WW: Passive smoking and heart disease. Mechanisms and risk. Jama $1995,273: 1047-1053$

105. Kawachi I, Colditz GA, Speizer FE, Manson JE, Stampfer MJ, Willett WC, Hennekens $\mathrm{CH}$ : A prospective study of passive smoking and coronary heart disease [see comments]. Cinculation 1997, 95:2374-2379

106. Izzotti A, De Flora S, Petrilli GL, Gallagher J, Rojas M, Alexandrov K, Bartsch H, Lewtas $\mathrm{J}$ : Cancer biomarkers in human atherosclerotic lesions: detection of DNA adducts. Cancer Epidemiol Biomarkers Prev 1995, 4:105-110

107. De Flora S, Izzotti A, Walsh D, Degan P, Petrilli GL, Lewtas J: Molecular epidemiology of atherosclerosis. Faseb J 1997, 11:1021-1031

108. Binkova B, Strejc P, Boubelik O, Stavkova Z, Chvatalova I, Sram RJ: DNA adducts and human atherosclerotic lesions. Int J Hyg Environ Healsb 2001, 204:49-54

109. Binkova B, Smerhovsky Z, Strejc P, Boubelik O, Stavkova Z, Chvatalova I, Sram RJ: DNA-adducts and atherosclerosis: a study of accidental and sudden death males in the Czech Republic. Mutat Res 2002, 501:115-128

110. Van Schooten FJ, Hirvonen A, Maas LM, De Mol BA, Kleinjans JC, Bell DA, Durrer JD: Putarive susceptibility markers of coronary artery disease: association between VDR genorype, smoking, and aromatic DNA adduct levels in human right atrial tissue. Faste f $1998,12: 1409-1417$ 



\section{Chapter 2}

\section{Modulation of plasma lipid levels affects benzo[a]pyrene-induced DNA damage in tissues of two hyperlipidemic mouse models}

Daniëlle M.J. Curfs, Linda Beckers, Roger W.L. Godschalk, Marion J.J. Gijbels, Frederik J. van Schooten 


\section{Abstract}

The role of plasma lipids in the uptake, transportation and distribution of lipophilic carcinogens like benzo[a]pyrene $(B[a] P)$ remains unclear. Therefore, we studied the effects of dietary-modulated plasma lipids on B[a]P-induced DNA damage in several organs of two hyperlipidemic mouse models. Male apolipoprotein $\mathrm{E}$ (apoE)*3-Leiden $(n=22)$ and apoE knockout (apoE-KO) mice $(n=20)$ were fed a high-fat cholesterol (HFC) diet or low-fat cholesterol (LFC; standard mouse chow) diet for three weeks, after which the animals were exposed to a single oral dose of $5 \mathrm{mg} / \mathrm{kg}$ bw B[a]P or vehicle and killed 4 days later. Plasma lipids were determined and DNA adducts were measured in aorta, heart, lung, liver, brain and stomach. Total cholesterol and low-density lipoprotein (LLDL) cholesterol were increased in all animals on a HFC diet, whereas a decrease of triglycerides was seen only in the apoE-KO mice. In apoE-KO mice on a normal diet, DNA adduct levels were highest in aorta $\left(10.8 \pm 1.4\right.$ adducts $/ 10^{8}$ nucleotides), followed by brain $(7.8 \pm 1.3)$, lung $(3.3 \pm 0.7)$, heart $(3.1 \pm 0.6)$, liver $(1.5 \pm 0.2)$ and stomach $(1.2 \pm 0.2)$. In the apoE*3-Leiden mice, adduct levels were equally high in aorta, heart and lung $(4.6 \pm 0.7,5.0 \pm 0.5$ and $4.6 \pm 0.4$, respectively), followed by stomach $(2.7 \pm 0.4)$, brain $(2.3 \pm 0.2)$ and liver $(1.7 \pm$ $0.2)$. In the apoE-KO mice, the HFC diet intervention resulted in lower adduct levels in lung $(2.1 \pm 0.2)$, heart $(1.9 \pm 0.2)$ and brain $(2.9 \pm 0.5)$ as compared with the LFC group. In contrast, a nonsignificant increase of adducts was found in aorta (13.1 \pm 1.5$)$. A similar trend was observed in the apoE*3-Leiden mice. Multiple regression analysis showed that in aorta, DNA adducts were inversely related to plasma triglycerides $(P=0.004)$ and additionally modulated by the apoE genotype $(P<0.001)$. The results of the present study support further investigation into the role of dicary modulation of plasma lipids, apoe, and polycyclic aromaric hydrocarbon (PAH) exposure on the formation of DNA adducts in chronic degenerative diseases, such as atherosclerosis. 


\section{Introduction}

Polycyclic aromatic hydrocarbons (PAHs) are products of the incomplete combustion of organic material and form a large group of lipophilic environmental carcinogens to which the general population is exposed daily. PAHs are present in cigarette smoke, in broiled and smoked foods, and in polluted air. The genotoxic effect of PAHs are dependent on their ability to be metabolically activated and bind covalently to DNA, forming PAH-DNA adducts. Measurement of nuclear DNA adducts is generally considered an important biomarker in determining the biologically effective dose and in evaluating the involvement of DNA alterations in chronic degenerative diseases like cancer and cardiovascular diseases (CVD). ${ }^{1-3}$

Cancer and CVD are the two most common causes of death in the Western world. Controlling these two diseases has proven extremely difficult because of their multiplicity, their inter- and intra-individual diversity, and their broad range of risk factors. Remarkably, both diseases appear to have several similarities in origin as well as in pathogenetic mechanisms, ${ }^{4}$ For example, both diseases seem to result from injury, which in turn can be linked to mutual controllable risk factors like dietary habits and smoking. ${ }^{5}$ The fact that exposure to environmental and lifestyle carcinogens like PAHs as well as obesity and hypercholesterolemia are linked to both cancer and CVD has lead to the suggestion that populations at high risk of cancer may also experience a high risk of atherosclerosis-related diseases. ${ }^{6}$

It is also well known that overweight individuals with increased overall dietary fat intake are more prone to develop both atherosclerosis and cancer. ${ }^{7}$ The increased plasma cholesterol levels are believed to alter gene expression, thereby making these individuals more susceptible to both these diseases, but the precise mechanism is unknown. ${ }^{7}$ It is suggested that smoking and serum cholesterol are not completely independent risk factors. ${ }^{8}$ To what extent these risk factors can act synergistically, and whether they have the same effect on atherosclerosis and cancer, needs further investigation.

The apolipoprotein E (apoE)*3-Leiden mouse and the apoE-deficient (apoE-KO) mouse are two mouse models of hyperlipidemia and atherosclerosis, in which plasma cholesterol levels can be modulated by diet. The apoE*3-Ieiden mouse is considered a mild hyperlipidemic mouse model. Although this mouse carries the defective human apoF*3-I siden gene, which results in significantly elevated levels of total cholesterol and triglycerides, it still has its endogenous apoE gene, which is capable of clearing small amounts of dietary lipids from the blood. The apoE-KO mouse, in contrast, lacks apoE and therefore suffers from high plasma cholesterol levels independent of the diet. ${ }^{9}$ 
In the present study, apoE-KO and apoE*3-Leiden mice were used to investigate the role of plasma lipids on the distribution of benzo[a]pyrene (B[a]P)induced DNA adducts in several organs important in chronic degenerative diseases (heart, aorta, lung and brain). Stomach was included, as this is the first-pass organ after oral $\mathrm{B}[\mathrm{a}] \mathrm{P}$ exposure, and liver was analyzed because of its metabolic importance.

\section{Materials and Methods}

\section{Chemicals and diet}

$\mathrm{B}[\mathrm{a}] \mathrm{P}$ and tricaprylin were purchased from Sigma (St. Louis, MO). The synthetic high-fat cholesterol (HFC) diets $\mathrm{N}$ and $\mathrm{W}$, as well as the standard mouse low-fat cholesterol (LFC) SRM-A, were supplied by Hope Farms (Woerden, The Netherlands). The composition of the diets is presented in Table 2.1.

Diet $\mathrm{N}$ is commonly used as a synthetic high-fat diet for the apoE*3Leiden mouse and is supplemented with $0.5 \%$ cholate to block cholesterol conversion to bile acids. The composition of diet W (the synthetic high-fat diet of the apoE-KO mouse) was comparable to diet $\mathrm{N}$, but without cholate. The levels of cholesterol and cellulose in diet $\mathrm{W}$ were set at $0.25 \%$ and $5.95 \%$, respectively.

Table 2.1 Composition of the semi-synthetic diets.*

\begin{tabular}{lccc}
\hline & LFC & HFC \\
\cline { 2 - 4 } & SRM-A & Diet W & Diet N \\
\hline Sucrose & 50.5 & 40.5 & 40.5 \\
Cornstarch & 12.2 & 10 & 10 \\
Cellulose & 5 & 5.95 & 4.7 \\
Corn oil & 5 & 1 & 1 \\
Cocon butrer & - & 1.5 & 15 \\
Cholesterol & - & 0.25 & 1 \\
Cholate & - & - & 0.5 \\
\hline
\end{tabular}

HFC. low fat cholesterol: HFC, high-fat cholesterol.

The composinon of the diets is presented in $\mathrm{g} / 100 \mathrm{~g}$ diet. In addition, the diets also contaned $20 \% \mathrm{casein}$, $1 \%$ choline chloride $(50 \% \mathrm{w} / \mathrm{v}) .0 .2 \%$ methionine, and $5.1 \%$ viamin and mincral mixture. The digestible energy contenis of the diers was $3,883 \mathrm{kcal} / \mathrm{kg}$ for the LFC dier and $4,356 \mathrm{kcal} / \mathrm{kg}$ for both diet W and diet N. 


\section{Animals}

Twenty male apoE-KO mice and 22 male apoE*3-Leiden (no. 2 line) mice entered the study between $8-10$ weeks of age. The apoE-KO mice were purchased from IFFA CREDO S.A. (a Charles River Co., Lyon, France) and the apoE*3-Leiden mice were bred within the animal facilities of the University of Maastricht. All animals were put on either a high-fat diet (diet $W$ and $\operatorname{diet} N$, respectively) or on a standard mouse chow (SRM-A) for 25 days.

Throughout the study period, animals were kept on a 12-hr light/dark cycle within the animal facilities of the University of Maastricht and were allowed free access to food and water. Growth was monitored during the experiment by weighing the animals at the beginning and at the end of the trial. The study was approved by the institutional commitree for the welfare of laboratory animals of the University of Maastricht.

\section{Carcinogen treatment and tissue bandling}

$\mathrm{A} B[\mathrm{a}] \mathrm{P}$ solution in tricaprylin was made by initially dissolving the $\mathrm{B}[\mathrm{a}] \mathrm{P}$ in acetone and adding it to the tricaprylin. Evaporation of the acetone under nitrogen resulted in a homogenous solution of $0.5 \mathrm{mg} \mathrm{B}[\mathrm{a}] \mathrm{P} / \mathrm{ml}$ tricaprylin. After three weeks of dietary intervention, animals were fasted overnight before receiving a single gavage dose of $5 \mathrm{mg} / \mathrm{kg}$ bw B[a]P or vehicle. Four days after the carcinogen treatment all animals were sacrificed. Approximately $0.5 \mathrm{ml}$ of blood was drawn from the inferior caval vein and used for the assessment of lipid levels. The arterial tree was perfused for 3 minutes with $0.9 \% \mathrm{NaCl}$ to remove all the blood within the aorta. Subsequently, the complete arterial tree, including the aortic arch with its main branch points (the brachiocephalic trunk, the left carotid artery and the left subclavian artery), the thoracic and abdominal aorta, the renal artery biranch points and further down as far as the iliac artery bifurcation, was excised and stripped of adipose tissue and was stored at $-20^{\circ} \mathrm{C}$ until DNA isolation. Heart, brain, lung, liver and stomach were removed and stored at $-20^{\circ} \mathrm{C}$. Pieces of the liver were fixed ovemight in formalin and embedded in paraffin for histological examination.

\section{Assessment of lipid levels}

Standard kits were used to measure total piasma cholesterol, total glycerol, free glycerol, and high-density lipoprotein (HDL) cholesterol on the Cobas Fara centrifugal analyzer (Hoffmann-La Roche, Basel, Swizzerland). Standardized serum (Precipath, Hoffmann-La Roche) was included with each series of assays as an internal standard. Low-density lipoprotein (I.DL) cholesterol was calculated in $\mathrm{mmol} / \mathrm{I}$, using the formula:

LDL cholesterol $=$ total cholesterol $-($ triglycerides $/ 2.2)-$ HDL cholesterol 


\section{DNA isolation and ${ }^{32}$ P-postlabeling}

Lung, liver, brain, stomach, heart and aortic tissues were cut into small pieces in SET/sodium dodecyl sulfate (SET/SDS: $100 \mathrm{mM} \mathrm{NaCl}, 20 \mathrm{mM}$ EDTA, $50 \mathrm{mM}$ Tris, $0.5 \%$ SDS). RNAse A $(0.1 \mathrm{mg} / \mathrm{ml})$ and RNAse $\mathrm{T} 1(1000 \mathrm{U} / \mathrm{ml})$ were added and incubated at $37^{\circ} \mathrm{C}$ for $1 \mathrm{hr}$. Liver tissue was also incubated with $\alpha$-amylase (10 $\mathrm{mg} / \mathrm{ml}$ ) for $1 \mathrm{hr}$ at $37^{\circ} \mathrm{C}$. Finally, all tissues were incubated overnight at $55^{\circ} \mathrm{C}$ with proteinase $\mathrm{K}(1 \mathrm{mg} / \mathrm{ml})$. DNA was extracted with $\mathrm{phenol} /$ chloroform/isoamyl alcohol (25:24:1) and chloroform/isoamyl alcohol (24:1). The DNA was precipitated using 2 volumes of cold ethanol after addition of $1 / 30$ volume $3 \mathrm{M}$ sodium acetate, and washed with $70 \%$ ethanol. The DNA was dissolved in $2 \mathrm{mM}$ Tris ( $\mathrm{pH} 7.4$ ) at a concentration of $2 \mathrm{mg} / \mathrm{ml}$.

The ${ }^{32} \mathrm{P}$-postlabeling assay was performed as described by Reddy and Randerath ${ }^{10}$ with some modifications. In short, $10 \mu \mathrm{g}$ DNA were digested with micrococcal endonuclease $(0.4 \mathrm{U})$ and spleen phosphodiesterase $(2.8 \mu \mathrm{g})$ for $3.5 \mathrm{~h}$ at $37^{\circ} \mathrm{C}$; afterward, the digest was treated with nuclease P1 $(6.3 \mu \mathrm{g})$ for $40 \mathrm{~min}$. Labeling was performed using an excess of $\left[\gamma^{-32} \mathrm{P}\right]-\mathrm{ATP}$ and $5 \mathrm{U}$ of T4 polynucleotide kinase. Radiolabeled adduct nucleotide biphosphates were separated by chromatography on poly(ethyleneimine) (PEI)-cellulose sheets (Machery Nagel, Düren, Germany) using the following solvent systems: D1, 1M $\mathrm{NaH}_{2} \mathrm{PO}_{4}, \mathrm{pH}$ 6.5; D2, 8.5 M urea, $5.3 \mathrm{M}$ lithium formate, $\mathrm{pH} 3.5 ; \mathrm{D} 3,1.2 \mathrm{M}$ lithium chloride, $0.5 \mathrm{M}$ Tris, $8.5 \mathrm{M}$ urea, $\mathrm{pH} 8.0$; D4, $1.7 \mathrm{M} \mathrm{NaH}_{2} \mathrm{PO}_{4}$, $\mathrm{pH}$ 6.0. In each run, 2 standards of $\left[{ }^{3} \mathrm{H}\right]$ benzo[a]pyrene diol epoxide (BPDE) modified DNA with known modification levels (1 per $10^{7}$ and $10^{8}$ nucleotides) were included for quantification purposes. Quantification was performed by phosphor-imaging technology (Moleculat Dynamics ${ }^{\mathrm{MM}}$, Sunnyvale, CA). To determine the final amount of DNA in the assay, one-half of the digest was diluted, and normal nucleotides were labeled with $\left[\gamma^{-32}\right]-A T P(20 \mu \mathrm{Ci} /$ sample $)$ by incubation with T4polynucleotide kinase $(2.5 \mathrm{U}$ ) and a 10-fold molar excess of unlabeled ATP for 30 min at $37^{\circ} \mathrm{C}$. In each run, a dAp standard $(27.5 \mathrm{pmole} / \mu \mathrm{l})$ was included for quantification purposes. Nucleotides were separated by one-dimensional chromatography on PEI-cellulose sheets from Merck (solvent: $0.12 \mathrm{M} \mathrm{NaH} \mathrm{PO}_{4}$. $\mathrm{pH}$ 6.8).

\section{Statistical analysis}

Results are presented as mean \pm standard error of the mean $( \pm$ SEM). Statistical evaluation of differences between groups was performed by means of the nonparametric Mann Whitney rank-sum U-test. Correlations between DNA adducts and other variables were examined using (multiple) linear regression. In all tests the level of statistical significance was set at $P<0.05$. 


\section{Results}

\section{Weight gain}

There was no difference in weight gain for apoE*3-Leiden mice fed the LFC and $\mathrm{HFC}$ diets for three weeks. On the other hand, apoE-KO mice on a HFC diet gained more weight than the LFC animals $(P<0.01$; Table 2.2$)$. Overall, the apoE$\mathrm{KO}$ mice on a HFC diet gained more weight than the apoE*3-Leiden mice on a. HFC diet $(P<0.01)$; there was no difference in weight gain for the mice fed LFC diet. The HFC diets resulted in enlarged livers in both mouse strains $(P<0.01)$.

Table 2.2 Growth and plasma lipid parameters of the apoE*3-Leiden and the apoE-KO mice.

\begin{tabular}{lcccc}
\hline & \multicolumn{2}{c}{ apoE*3-Leiden } & \multicolumn{2}{c}{ apoE-KO } \\
\cline { 2 - 5 } & \multicolumn{1}{c}{ LFC } & HFC & LFC & HFC \\
& $(n=11)$ & $(n=11)$ & $(n=5)$ & $(n=5)$ \\
\hline $\begin{array}{l}\text { Weight gain }(\Delta) \\
\text { Relative liver }\end{array}$ & $1.91 \pm 0.46$ & $2.19 \pm 0.34$ & $-0.11 \pm 0.22$ & $2.54 \pm 0.47^{*}$ \\
weight & $0.049 \pm 0.003$ & $0.074 \pm 0.000^{*}$ & $0.042 \pm 0.005$ & $0.050 \pm 0.000^{*}$ \\
Total Cholesterol & $1.99 \pm 0.44$ & $16.53 \pm 3.27^{* *}$ & $7.8 \pm 3.01^{* *}$ & $15.51 \pm 2.36^{* *}$ \\
(mmol/L) & & & & \\
Triglycerides & $1.28 \pm 0.50$ & $1.42 \pm 0.56$ & $1.41 \pm 0.43$ & $0.81 \pm 0.17^{* *}$ \\
(mmol/L) & & & & \\
HDL (mmol/L) & $0.35 \pm 0.21$ & $0.35 \pm 0.26$ & $0.55 \pm 0.65$ & $2.00 \pm 1.89$ \\
$\mathrm{LDL}^{\mathrm{b}}(\mathrm{mmol} / \mathrm{L})$ & $1.26 \pm 0.68$ & $15.39 \pm 3.13^{* *}$ & $6.6 \pm 2.4^{* * *}$ & $14.04 \pm 2.98^{* *}$ \\
\hline
\end{tabular}

apoE, apolipoprotein E: KO, knockout; LFC, low-fat cholesteral: HFC, high-fat cholesterol: HDI, highdensity lipoprotein; LDL, low-densiry lipoprotein.

aliver weight is corrected for total body weight.

${ }^{b}$ Caleulated as described in Marerials and Merhods.

$* P<0.01$ vs. LFC

$* P<0.05$ vs. LFC.

$* * * P<0.05$ vs. LFC apoE*3-Leiden.

\section{Macroscopic and microscopic evaluation of livers}

Since the livers in the HFC diet groups were enlarged compared to the LFC diet groups, we further examined livers of all animals both macroscopically and microscopically. Macroscopic examination showed solid white livers in the HFC apoE*3-Leiden mice, whereas no abnormalities were observed in the livers of the apoE-KO mice on a HFC diet. Both macroscopic and microscopic evaluation of livers showed no abnormalities for all animals on LFC diet. Microscopic 
examination of liver sections from the apoE-KO mice on a HFC diet indicated some very mild steatosis (triglyceride deposition). Liver sections of apoE*3-Leiden mice on the HFC diet were characterized by moderate steatosis as well as the characteristic E*3-Leiden protein bodies." Furthermore, a moderate, predominantly periportal infiltration of lymphocytes and macrophages due to single hepatocyte cell necrosis was observed. Steatosis is a normal result of the high-fat diet, whereas the infiltration is a regular symptom of dietary cholate. ${ }^{12}$

\section{Plasma lipid levels}

As expected, levels of total cholesterol and LDL were higher in the L.FC fed apoE$\mathrm{KO}$ mice than in the apoE*3-Leiden mice $(P<0.01$; Table 2.2). When animals were put on a HFC diet, the levels of total cholesterol and concomitant LDL. cholesterol were raised in both mouse strains to a similar level. In the apoE-KO mice on the HFC diet triglyceride levels lowered significantly $(0.81 \pm 0.17$ vs. 1.41 $\pm 0.43 \mathrm{mmol} / \mathrm{L}, P<0.05$; Table 2.2). Overall, the HFC diets increased total cholesterol and LDL cholesterol in both mouse models, whereas triglycerides were only affected in the apoE- $\mathrm{KO}$ mice.

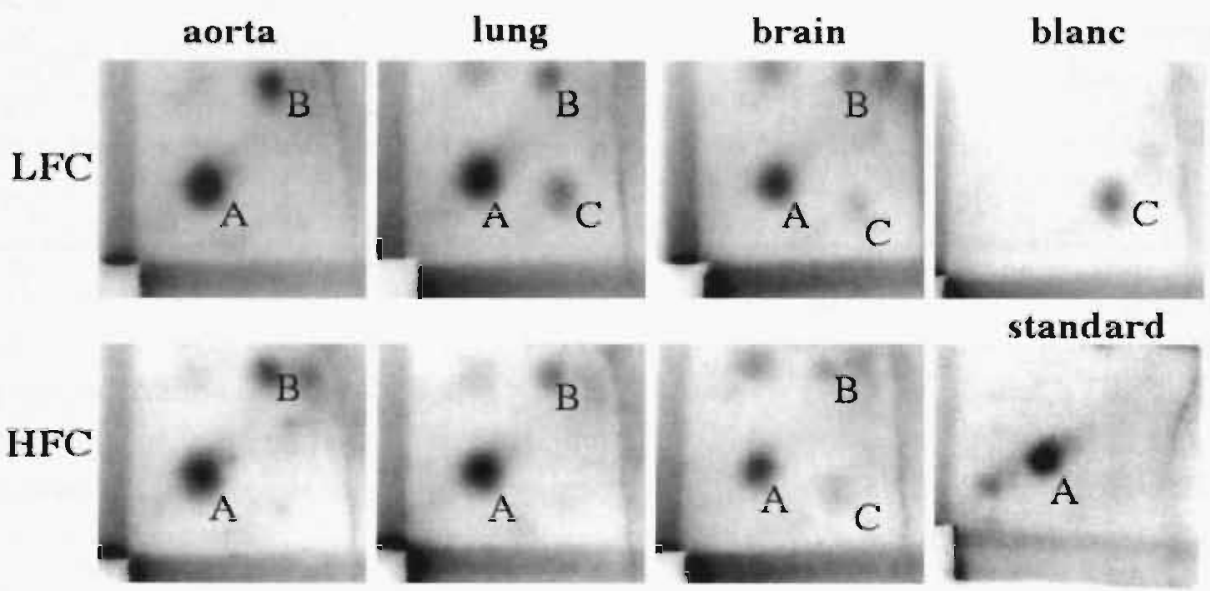

Figure 2.1 DNA adduct profiles in benzo[a]pyrene (B[a]P)-exposed apoE*3-Leiden mice on a low-fat cholesterol (L.FC; normal mouse chow) or high-fat cholesterol (HFC) diet.

Adduct profiles are shown for aorta, lung, and brain. Quantitation was based on the majot adduet spot (A) which co-mignited with the standard (1 BPDE-DNA adduct per $10^{7}$ nucleotides). A second minor adduct spor (B), which was not seen in the standard, was not included in the analysie. The spot seen in the blane (C) was considered as background. 


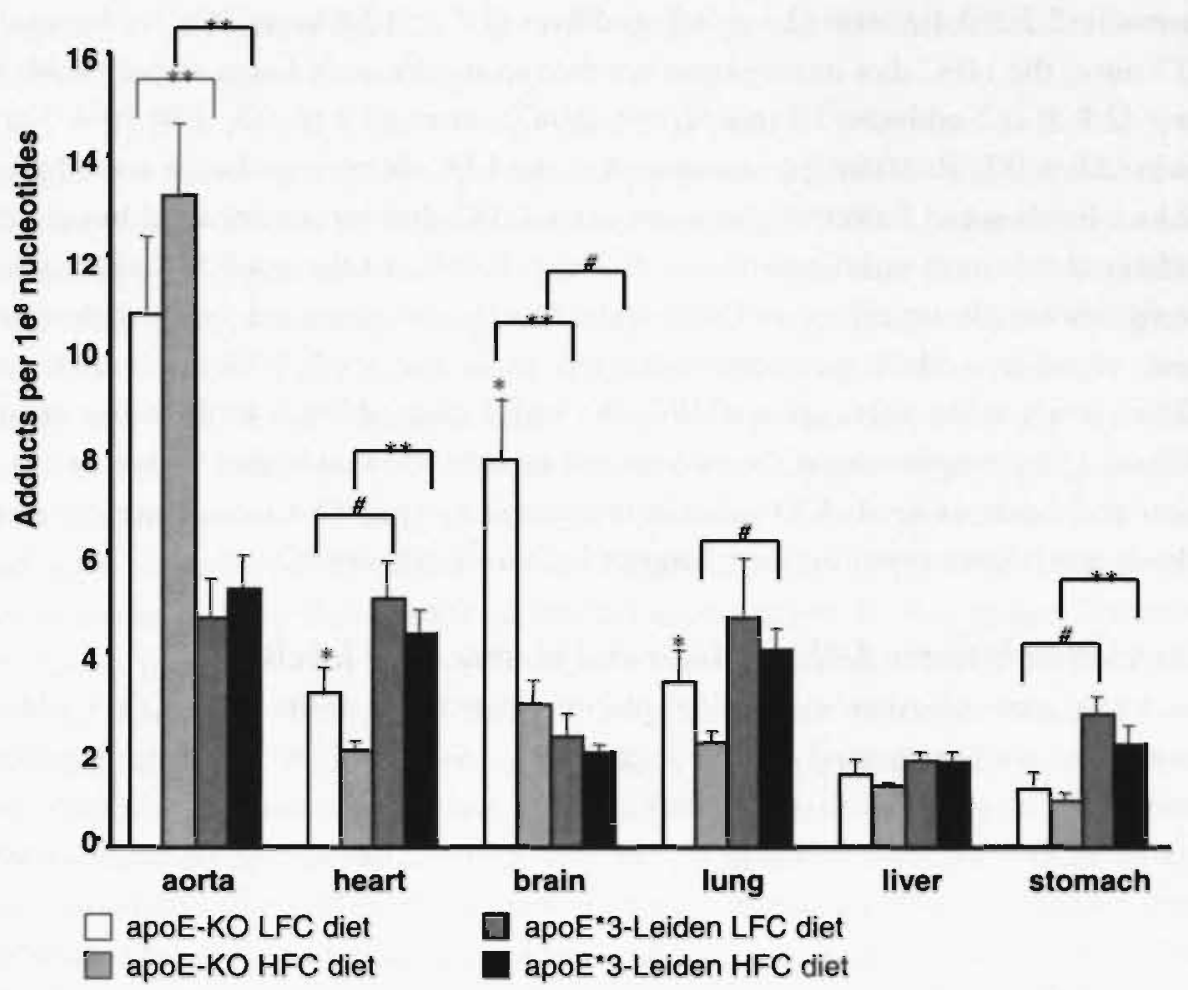

Figure 2.2 Benzo[a]pyrene (B[a]P)-induced DNA-adduct levels in apoE*3-Leiden mice and apoE-knockout (KO) mice fed a low-fat cholesterol (LFC) or high-fat cholesterol (HFC) diet. ${ }^{\mathrm{P}}<0.05$ compared with the HFC group. " $\mathrm{P}<0.01$ apoE*3-Leiden mice vs, apoE-KO micc. \#P<0.05, apoE*3-Leiden mice vs, apoE-KO mice.

\section{DNA-adducts and diet}

$\mathrm{B}[\mathrm{a}] \mathrm{P}$-induced DNA adducts were measured in aorta, heart, lung, liver, brain and. stomach tissue of ail animals. In both animal models, there was no influence of diet on B[a]P-DNA-adduct profiles (see Figure 2.1): in all organs, only the major adduct spot (adduct $\mathrm{A}$ ) which co-chromatographed with the BPDE-DNA adduct standard, was used for quantitation purposes. Inclusion of the minor DNA-adduct spot (adduct B) in the quantiation did not influence the results. No addact spots were found in the 10 apoE- $\mathrm{KO}$ mice, that received the vehicle only. ApoE-KO mice fed a LFC diet showed the highest adduct levels in aorta $(10.8 \pm 1.4$ adducrs $/ 10^{8}$ nucleotides), followed by brain $(7.8 \pm 1.3)$, hung ( $\left.3.3 \pm 0.7\right)$, heart (3.1 $\pm 0.6)$, liver $(1.5 \pm 0.2)$ and stomach $(1.2 \pm 0.2$; Figure 2.2$)$. In the apoE*3-Leiden mice on a LFC diet, adduct levels were comparably high in aorta, heart and lung 
(4.6 $\pm 0.7,5.0 \pm 0.5$ and $4.6 \pm 0.4$ adducts $/ 10^{8}$ nucl, respectively), followed by stomach $(2.7 \pm 0.4)$, brain $(2.3 \pm 0.2)$ and liver $(1.7 \pm 0.2$; Figure 2.2$)$. In the apoE$\mathrm{KO}$ mice, the $\mathrm{HFC}$ diet intervention resulted in significantly lower adduct levels in lung ( $2.1 \pm 0.2$ adducts $/ 10^{8}$ nucl., $\left.P=0.047\right)$, heart $(1.9 \pm 0.2, P=0.047)$ and brain $(2.9 \pm 0.5, P=0.009)$ as compared to the LFC diet group. In contrast, higher adduct levels were found in the aorta after HFC diet intervention, although the difference was non-significant $(5.2 \pm 0.7, P=0.465)$. In the apoE*3-Leiden mice, no significant dietary effect on DNA adduct levels was observed. Nevertheless, the same trend in adduct formation occurred as in the apoE-KO mice: increased adduct levels in the aorta upon a HFC diet and decreased levels in the orher organs (Figure 2.2). Comparison of the two mouse models showed higher adduct levels in aorta and brain of apoE-KO mice as compared to apoE*3-Leiden mice, whereas adduct levels were lower in heart, lung and stomach (Figure 2.2).

\section{Correlation between DNA adducts and plasma lipid levels}

To investigate whether circulating plasma-lipid levels influenced DNA-adduct formation, we performed simple regression analysis. This regression analysis indicated that plasma total cholesterol, HDL, and LDL concentrations were not related to DNA-adduct levels in any of the organs. Although DNA-adduct levels were modulated by diet in heart, lung and brain of apoE-KO mice, this effect was not clearly related to changes in plasma lipid levels. In contrast, a good correlation was found between triglyceride levels and DNA-adduct formation in aorta (Figure 2.3). To investigate further which factors (diet, plasma lipid levels, mouse genotype) determined DNA-adduct levels, a stepwise multiple regression analysis was performed. The regression model showed that mouse genorype $(P<0.001)$ and plasma triglyceride levels $(P=0.004)$ significantly explained the DNA adduct levels in aorra (overall $\mathrm{R}^{2}=0.718, P<0.001$ ).

\section{Discussion}

In the present study, we examined whether dietary modulation of plasma lipid levels had an effect on B[a]P-DNA-adduct levels and distribution patterns in several organs of two hyperlipidenic mouse models. Generally, we found that DNA-adduet levels were high in aorta as compared with other organs, indicating that the aorta is a potential rarget rissue for the genotoxic effects of $\mathrm{B}[\mathrm{a}] \mathrm{P}$. The HFC diet resulted in higher adduct levels in the aora than did a LFC diet, whereas the opposite was observed for the other organs examined. Looking more closely into the relation between plasma lipids and adduct levels, a cleat inverse correlation 
between DNA adducts and triglyceride levels was seen only for aorta. Surprisingly, a strong modulating effect of the apoE genotype on DNA-adduct levels was observed in all organs except for liver.

$\mathrm{B}[\mathrm{a}] \mathrm{P}$ is probably the most studied $\mathrm{PAH}$ and is often used as indicator to quantify environmental $\mathrm{PAH}$ exposure. ${ }^{13} \mathrm{~B}[\mathrm{a}] \mathrm{P}$ must be metabolically activated by cytochrome P-450 into its ultimate reactive metabolite BPDE before it can cause any damage in organisms. In this study we have shown that B[a]P-DNA-adduct levels were high in aorta and lung, and in apoE-KO mice, also in brain and heart. The link between PAH exposure and chronic degenerative diseases like lung cancer and CVD is well documented. ${ }^{3,13}$ It is known that the vessel wall, just like lung, possesses cytochrome P-450, and is therefore capable of activating B|a|P. ${ }^{14}$ However, in contrast to lung tissue, cell proliferation in heart and aorta is low, making it easier for DNA adducts to accumulate. On the other hand, because cell proliferation is low, the chance of mutation induction is also lower. Previous studies performed in rats exposed to PAHs have shown high DNA-adduct levels in lung, aorta and heart. ${ }^{15,16}$. These data confirm that aorta may indeed be a potential target for B[a]P. Moreover, Gairola $e t a .^{17}$ showed that chronic exposure to PAHs leads to an enhanced progression of atherosclerosis in apoE- $\mathrm{KO}$ mice, in agreement with the results obtained from a comparable study performed in our own lab (chapters 4 and 5). In humans, the "bulky" aromatic DNA adducts, which are most likely related to environmental exposure to genotoxic chemicals, were a significant predictor of the stage of atherosclerosis..$^{18}$

There is evidence that $\mathrm{B}[\mathrm{a}] \mathrm{P}$ may enter the blood and reach the arterial wall through transport in lipoproteins. ${ }^{19}$ Modulation of lipoproteins could thereby increase or decrease the available dose of $\mathrm{B}[\mathrm{a}] \mathrm{P}$ for the vessel wall and simultaneously influence the dose for other organs, leading to altered DNA-adduct levels. Morcover, modulation of lipoprorein levels can also influence DNA-repair mechanisms. For example, diet-induced hypercholesterolemia in rabbirs is associated with upregulation of DNA-repair enzymes. ${ }^{20}$ In out study, the observed differences in B[a]P-DNA damage produced by diet were more pronounced in the more severe hyperlipidemic apoE-KO mouse compared with the apoE*3-Leiden mouse. Especially for heart, brain and lung tissue, the apoE-KO mice showed a significant reduction in adduct levels in the HFC group compared with the LFC group. However, we observed that although the HFC diets produced similar total plasma cholesterol and concomitant plasma LDL cholesterol in the two mouse models, DNA-adduct levels were not affected. Thus, it seems that modulation of plasma total cholesterol and LDL, cholesterol is not the predominant determinant for the ultimate biologically effective dose of $\mathrm{B}[\mathrm{a}] \mathrm{P}$. 


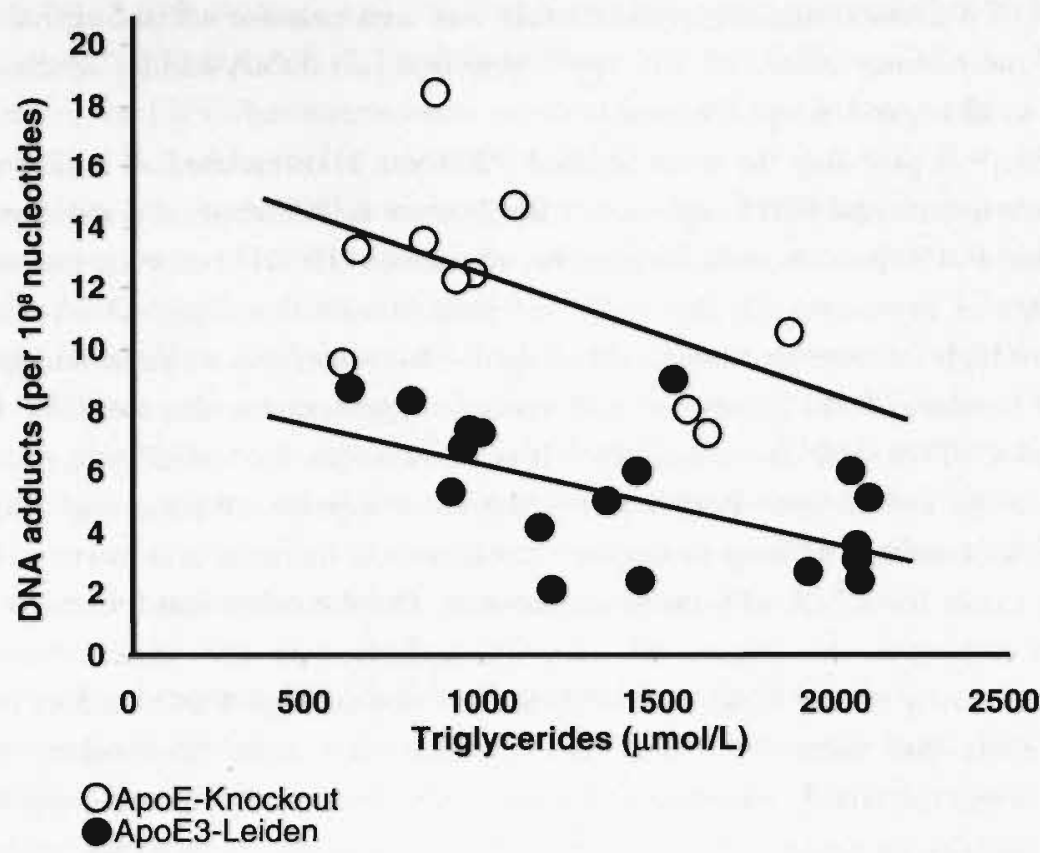

Figure 2.3 Simple regression analysis of [triglyceride] versus DNA adducts in aorta of apoE-KO $(\mathrm{R}=0.53, P=0.11)$ and apoE*3-Leiden mice $(\mathrm{R}=0.55, P=0.02)$.

In vitro data indicate that triglyceride concentrations are more directly correlated with $\mathrm{B}[\mathrm{a}] \mathrm{P}$ uptake than are concentrations of other lipoproteins, and suggest that a small change in serum triglyceride concentration could cause a significant change in uptake of $\mathrm{B}[\mathrm{a}] \mathrm{P}$, thereby influencing the level of circulating carcinogen. ${ }^{21}$ In this study, simple regression analysis showed a significant inverse relationship between triglyceride concentrations and DNA adduct levels in the aorta of the apoE*3-Leiden mice. Although this relationship was not significant in the apoE-KO mice, the regression lines for the rwo mouse models were parallel (Figure 2.3). Therefore, we included both triglyceride levels and mouse strain in a multiple regression analysis that indicated a strong orerall correlation between these factors and aoric DNA-adduct levels. In the other organs, with the exception of liver, multiple regression analysis indicated that neither diet nor dietary modulation of triglycerides is a strong predictor of DNA-adduct levels, but that mouse strain is.

Furthermore, our results suggest that the differences in adduct formation due to the mouse strain are organ specific: in aorta and brain, DNA-adduct levels were higher in apoE-KO'mice than in apoE*3-Leiden mice, whereas, in lung. heart, and stomach, the opposite was observed. For brain, important in 
cerebrovascular diseases, our results were not completely as expected. For example, mice with a deficiency in apoE have a disturbance in the blood-brain barrier, which is even more severe when the animals are put on a HFC diet. The apoE*3-Leiden mouse did not show this disturbance even when fed a HFC diet. ${ }^{22}$ Our results showed that apoE-KO mice had higher adduct levels in brain than the apoE*3-Leiden mice, but these levels were higher in the LFC group than in the HFC group.

The results of the present study indicate that the apoE genotype modulates the ultimate biologically effective dose of $\mathrm{B}[\mathrm{a}] \mathrm{P}$. ApoE is a major component of triglyceride-rich lipoproteins and HDL. ${ }^{23}$ It plays a pivotal role in lipid metabolism and contributes more to normal cholesterol variability than any other gene identified thus far. ${ }^{24}$ In the human population the $A P O E$ gene is polymorphic with three common alleles, ${ }^{*} \varepsilon 2,{ }^{*} \varepsilon$, and ${ }^{*} \varepsilon$. The $\left.\varepsilon\right\}$ allele is the most common form in general populations and comparatively, the $\varepsilon 2$ allele lowers total cholesterol levels while $\varepsilon 4$ raises them. In general, the $\varepsilon 2$ allele is considered to have a protective effect for coronary heart diseases (CHD), whereas carriers of the $\varepsilon 4$ allele are at increased risk. ${ }^{25}$ Several studies have tried to assess the relationship between smoking, APOE polymorphism and CHD, but the results are controversial. 18,23,24,26 Although Liu et al..$^{23}$ did not find an interaction between smoking and the E4 polymorphism on CVD, Karvonen et al..$^{24}$ described such an interaction, but only for hypertensive smoker. Finally, a third study, which analyzed DNA-adducts in human thoracic aortas taken at autopsy, showed that the lowest values of both LDL cholesterol and DNA-adducts were seen in subjects possessing the $\varepsilon 2$ allele. ${ }^{18}$ Although triglyceride levels were not influenced by diet, the results of our study showed an inverse correlation between the individual plasma triglyceride levels and adduct levels in aorta. Since this correlation was not clearly diet dependent, any possible synergistic effect of $a p o E$ genotype and DNA adduct formation affer $\mathrm{B}[\mathrm{a}] \mathrm{P}$ exposure cannot be explained merely by differences in (dietary modulated) lipid levels.

In conclusion, we used two hyperlipidemic mouse models to study the effects of dietary modulation of plasma lipids on DNA-adduct formation. Surprisingly, in addition to the effects of diet and plasma triglyceride levels on adduct formation, we also found an effect of the apoE genotype. The DNA-adduct levels were different in the two mouse models although they have a similar genetic background, indicating that apoE plays a role in the genotoxic effects of $\mathrm{B}[\mathrm{a}] \mathrm{P}$. The results presented in the current study support further investigation into the role of dietary modulation of plasma lipids (especially triglyceride levels), apoE and. PAH exposure on the formation of DNA adducts in chronic degenerative diseases such as cardiovascular and cerebrovascular diseases and cancer. 


\section{References}

1. Izzotti A, De Flora S, Petrilli GL, Gallagher J, Rojas M, Alexandrox K, Bartsch H, Lewtas J: Cancer biomarkers in human atherosclerotic lesions: detecrion of DNA adducts. Cancer Epidemiol Biomarkers Prev 1995, 4:105-110

2. Binkova B, Strejc P, Boubelik O, Stavkova Z, Chvatalova I, Sram RJ: DNA adducts and human atherosclerotic lesions. Int J Hyg Emvion Health 2001, 204:49-54

3. Van Schooten FJ, Hirvonen A, Maas LM, De Mol BA, Kleinjans JC, Bell DA, Durrer JD: Putative suscepuibility markers of coronary artery disease: association between VDR genotype, smoking, and aromatic DNA adduct levels in human right atrial tissue. Faseb J $1998,12: 1409-1417$

4. Ross JS, Stagliano NE, Donovan MJ, Breitbart RE, Ginsburg GS: Atherosclerosis and cancer: common molecular pathways of disease development and progression. Ann N Y Acad Si 2001, 947:271-292; discussion 292-273

5. De Flora S, Izzotti A, Randerath K, Randerath E, Bartsch H, Nair J, Balansky R, van Schooten F, Degan P, Fronza G, Walsh D, Lewtas J: DNA adducts and chronic degenerative discase. Pathogenetic relevance and implications in preventive medicine. Mutat Res 1996, 366:197-238

6. Hansen ES: International Commission for Protection Against Environmental Mutagens and Carcinogens. ICPEMC Working Paper $7 / 1 / 2$. Shared risk factors for cancer and atherosclerosis--a review of the epidemiological evidence. Mutat Res 1990, 239:163-179

7. Jump DB, Clarke SD: Regulation of gene expression by dietary fat. Amu Rev Nutr 1999, 19:63-90

8. Perkins KA: The synergistic effect of smoking and serum cholesterol on coronary heart disease. Health Psychol 1985, 4:337-360

9. Fazio S, Linton MF: Mouse models of hyperlipidemia and atherosclerosis. Front Biosa 2001, 6:D515-525

10. Reddy MV, Randerath K: Nuclease PI-mediated enhancement of sensitivity of $32 \mathrm{P}$ postlabeling test for structurally diverse DNA adducts. Carcinogenesis 1986, 7:1543-1551

11. Mensenkamp AR, van Luyn MJ, van Goor H, Bloks V, Apostel F, Greeve J, Hofker MH, Jong MC, van Vlijmen BJ, Havekes LM, Kuipers F: Hepatic lipid accumulation, altered very low density lipoprotein formation and apolipoprotein $\mathrm{E}$ deposition in apolipoprotein E3-Leiden transgenic mice. J Hepato! 2000, 33:189-198

12. Van Nieuwkerk CM, Elferink RP, Groen AK, Otienhoff $R$, Tytgat GN, Dingemans KP. Van Den Bergh Weerman MA, Offerhatis GJ: Effects of Ursodecaycholate and cholate feeding on livet disease in FVB mice with a disruped mir2 P-glycoprotcin gene. Gastroenterology 1996, 111:165-171

13. Godschalk R, Nair J, van Schooten FJ. Risch A. Drings P. Kayser K, Dienemann H. Bartsch H: Comparison of multiple DNA adduct types in tumor adjacent human lung tissue: effect of cigarette smoking. Cancinogenesis 2002, 23:2081-2086

14. Juchau MR, Bond JA, Bendirt EP: Aryl 4-monooxygenase and cytochrome P.450 in the aorta: possible role in atherosclerosis. Proc Natl Acad Sa U S A 1976, 73:3723-3725

15. Godschalk RW, Vermeec IT, Kriek E. Floot B, Schilderman PA, Moonen EJ, Kleinjans JC, van Schooren FI: Comparison of 32P-postlabeling and HPIC-FD analysis of DNA adducts in rats acutely exposed to benzo(a)pyrene. Chem Biol Interact 1997, 104:41-54

16. Izzotii $A$, Camoiraño A, Cariglia C, Tampa E, De Flora S: Fomation of DNA adducis in the aorta of smoke-exposed rats, and modularion by chemopreventive agents. Mutat Res 2001, 494.97-106

17. Gairola CG, Drawdy ML, Block AE, Daugherty A: Sidestream cigarette smoke accelerates atherogenesis in apolipoprotein E-/- mice. Atherosclerosis 2001, 156:49-55

18. Binkova B. Smerhovsky Z. Strejc P. Boubelik O, Stavkova Z. Chvatalova I, Sram RJ: DNA-adducts and atherosclerosis: a study of accidental and sudden death males in the Czech Republic. Mutat Res 2002, 501:115-128 



\section{Chapter 3}

\section{Benzo[a]pyrene enhances lipid peroxidation induced DNA damage in aorta of apolipoprotein E knockout mice}

Roger W.L. Godschalk, Daniëlle M.J. Curfs, Helmut Bartsch, Frederik J. van Schooten, Jagadeesan Nair 


\section{Abstract}

The genotoxic compound benzo[a]pyrene (B[a]P) enhances atherosclerotic plaque progression, possibly by inducing oxidative stress and subsequent lipid peroxidation (LPO). Since LPO plays a key role in atherosclerosis, stable LPO derived DNA modifications such as $1, N^{6}$-ethenodeoxyadenosine $(\varepsilon \mathrm{dA})$ and $3, N^{4}$ ethenodeoxy-cytidine $(\varepsilon \mathrm{dC})$ may be useful biomarkers for in vivo oxidative stress. In this study, benzo[a]pyrene-diol-epoxide (BPDE)-DNA, $\varepsilon \mathrm{dA}$ and $\varepsilon \mathrm{dC}$ were determined by ${ }^{32} \mathrm{P}$-postlabelling in apolipoprotein $\mathrm{E}$ knockout (ApoE-KO) mice treated with $5 \mathrm{mg} / \mathrm{kg}$ B[a]P by gavage. After 4 days, BPDE-DNA adduct levels were higher in aorta $\left(10.8 \pm 1.4\right.$ adducts $/ 10^{8}$ nucleotides $)$ than in lung $(3.3 \pm 0.7$, $P<0.05$ ), which is a known target organ for $B[a] P$. Levels of $\varepsilon d A$ were higher in aorta of B[a]P-exposed animals than in unexposed controls $(8.1 \pm 4.4$ vs $3.4 \pm 2.1$ adducts per $10^{8}$ parent nucleotides, $P<0.05$ ). On the other hand, $\varepsilon \mathrm{dC}$ levels were not affected by B[a]P exposure. Serum low density lipoprotein (LDL) levels were lower in B[a]P-exposed mice than in controls $(9.3 \pm 3.7$ and $13.3 \pm 4.0 \mathrm{mmol} / \mathrm{l}$, respectively), whereas high density lipoprotein (HDL) levels were higher $(1.4 \pm 1.6$ and $0.4 \pm 0.3 \mathrm{mmol} / \mathrm{l}$, respectively). Consequently, a 3 -fold difference in the $\mathrm{LDL} / \mathrm{HDL}$ ratio was observed $(P=0.001)$. $\varepsilon \mathrm{dA}$ levels were positively related with plasma HDL concentrations $(R=0.68, P=0.02)$, suggesting that the HDL mediated protection of the vessel wall against reactive lipid peroxides was reduced in B[a]P-exposed apoE-KO mice. Our observations show that direct as well as lipid peroxidation induced DNA damage is formed by $\mathrm{B}[\mathrm{a}] \mathrm{P}$ in aorta of apoE-KO mice, which may be involved in atherosclerotic plaque progression. This study further indicates that erheno-DNA adducts are useful biomarkers for in vivo oxidative stress in atherosclerosis. 


\section{Introduction}

Cardiovascular diseases and cancer are both characterised by uncontrolled proliferation of cells and share common risk factors, such as cigarette smoking and dietary habits. ${ }^{1}$ Autopsy studies demonstrated that atherosclerosis and cancer tend to occur in the same individuals, ${ }^{2}$ and these observations led to the hypothesis that the process of atherogenesis may develop like a benign tumour according to an initiation-promotion mechanism. ${ }^{2}$ In this monoclonal theory of atherosclerosis, it is hypothesized that monoclonal expansion of cells in atherosclerotic plaques may result from acquired mutations due to DNA damage, caused directly by mutagenic agents (e.g., benzo[a]pyrene, B[a]P) or agents endogenously generated by oxidative stress/ lipid peroxidation inflicted by inflammation. Earlier studies indeed suggested that acquired mutations initiate at least part of the atherosclerotic lesion. ${ }^{3,4}$ Although the monoclonal theory of atherosclerosis is disputed, it does not completely contradict the response-to-injury theory, in which it is hypothesized that atherosclerosis is a vascular reaction towards inflammatory insults.

Oxidative stress, which plays a key role in the onset and progression of atherosclerosis and cancer, can cause DNA damage and many human cancers are thought to arise from mutations as a result of persistent DNA damage during cell replication. DNA bases damaged by reactive oxygen species and proteins modified by lipid peroxidation products have indeed been detected in human atherosclerotic lesions. ${ }^{5}$ One of the lipid peroxidation products, trans-4-hydroxy-2-nonenal (HNE), is known to bind covalently to cellular DNA after its epoxidation to form exocyclic etheno-base adducts (Figure 3.1). ${ }^{6}$ Among the etheno-bridged base modifications, $1, N^{6}$ ethenodeoxyadeñine $(\varepsilon d A)$ and $3, N^{4}$-erhenodeoxycytosine $(\varepsilon d C)$ are the most studied ones and were found to be highly miseoding lesions.? Therefore, these types of DNA adducts are promising early stable biomarkers for DNA damage caused by oxidative stress/ lipid peroxidation in the pathogenesis of atherosclerosis.

Major advances have been made in our understanding of the role of apolipoprotein E in the onset and development of atherosclerosis. Enhanced oxidative stress has been found in apolipoprotein E knockout mice (apoE-KO mice), which develop severe spontaneous atherosclerosis. ${ }^{8}$ Using antibodies directed against HNE-lysine conjugate, increased levels of low-density lipoprotein (LDL)-oxidation specific epitopes have been identified in aortic lesions of ApoE$\mathrm{KO}$ mice. Moreover, high titers of autoantibodies against the malondialdehydelysine conjugate have been measured in serum of these animals. ' Circulating lipoproteins in ApoE-deficient mice are more oxidized and more susceptible to oxidation than lipoproteins from wild-type animals. ' Therefore, ApoE-KO mice 
offer an excellent animal model to investigate the role of oxidative stress induced DNA damage in vascular diseases.

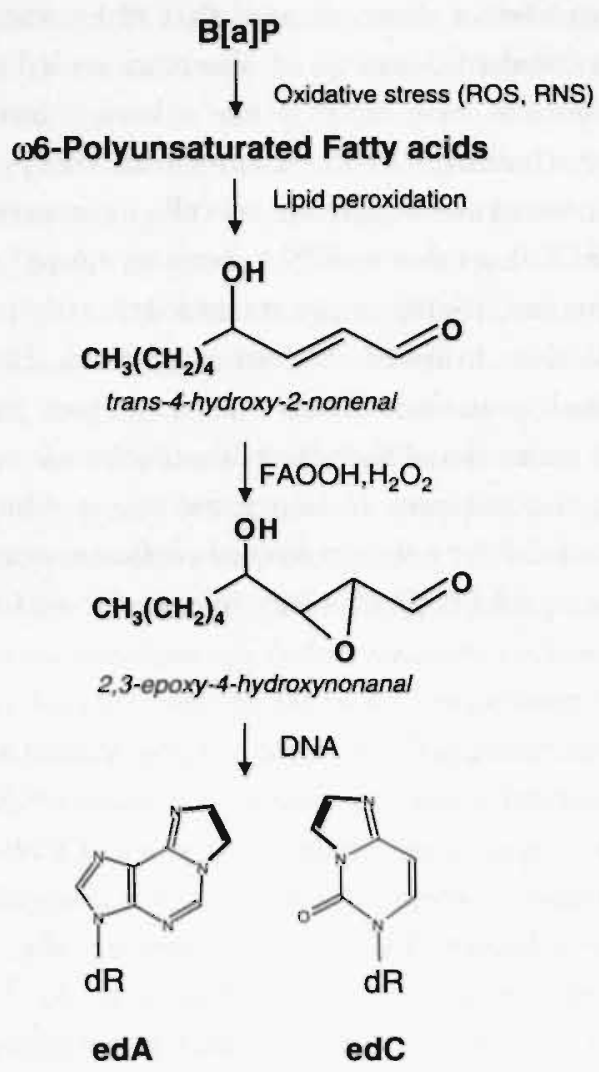

Figure 3.1 Scheme of formation of etheno-DNA adducts after B[a]P exposure.

Thans-4-hydoxy-2-nonenal (HNE) is fomed by the action of seactive oxygen and nirugen species (ROS and RNS, resp.). HNE is converted to 2,3-epoxy-4hydtoxynonanal by fanty acid hydroperoxides, which subsequently reacts covalently with DNA to form etheno-bridged base modifications (indicated with bold lines in the chemical structures of $1, N^{6}$-ethenodeoxyadenosine $[\mathrm{EdA}]$ and $3, N^{4}$-ethenodeoxycytidine $[\mathrm{EdC}$.

It is known that diet and smoking are separately as well as synergistically acting risk factors in both carcinogenesis and atherogenesis. B[a]P is a well known genotoxic compound, present in cigarette smoke and pyrolysed food products, for instance grilled meat. Exposure to B $[\mathrm{a}] \mathrm{P}$ may result in the formation of bulky DNA adducts, but is also linked to oxidative stress and subsequent lipid peroxidation, ${ }^{10}$ which might be associated with the $\mathrm{B}[\mathrm{a}] \mathrm{P}^{\mathrm{H}}$-related vascular toxicity. In the present study, we investigated whether exposure to this environmental carcinogen, which 
was found to influence plaque progression in apoE-K.O mice (chapter 4), ${ }^{11}$ affects lipid peroxidation in vivo and subsequent formation of etheno-DNA adducts in mouse aorta.

\section{Materials and Methods}

\section{Animals and their treatment}

Twenty male 6-8 weeks-old apoE-knockout C57Bl/ 6 mice (purchased from IFFA CREDO S.A. a Charles River Co, Lyon, France) were used. The animals were put either on a high fat/ high cholesterol diet (HFC; 16\% fat, predominantly cocoabutter which contains $35 \%$ stearic acid, $35 \%$ oleic acid, $25 \%$ palmitic acid, $3 \%$ linoleic acid and $2 \%$ others) or a normal mouse chow (LFC, $6.3 \%$ crude fat, SRMA, Hope Farms, Woerden, The Netherlands) during 25 days (10 animals per group). Four days before the end of the experiment and after an overnight fasting period, all animals received either a single oral dose by gavage of $5 \mathrm{mg} / \mathrm{kg}$ bw $\mathrm{B}$ [a]P (Sigma, St. Louis, MO, USA) dissolved in tricaprylin (5 animals on HFC and 5 on LFC diet) or vehicle only. Animals were anaesthetized by i.p. injection of Nembutal $^{\otimes}$ ( $0.5 \mathrm{ml}$ sodium phenobarbital/ kg bw). Approximately $0.5 \mathrm{ml}$ blood was drawn from the inferior caval vein and used for measurement of lipid levels. The arterial tree was perfused in situ for 3 minutes with $0.9 \% \mathrm{NaCl}$ via a catheter into the left ventricular apex. Subsequently, lungs and the arterial tree (abdominal aorta, thoracic aorta and the aortic arch including the brachiocephalic trunk, left carotid artery and left subclavian artery) were dissected and stored at $-80^{\circ} \mathrm{C}$ until DNA isolation.

\section{DNA isolation}

Lung tissue and the complete aorta wete homogenized in lysis-buffer (DNAisolation kit supplied by Qiagen, Hilden, Germany) using a polytron hamogenizer $(15,000 \mathrm{pm}$ for $30 \mathrm{sec})$. Proteinase $\mathrm{K}$ and RNases were added, followed by a 2 hours incubation at $50^{\circ} \mathrm{C}$. Subsequently, DNA was isolated using Qiagen columns according to the manufacturer's protocol with the following modification of the supplied elution buffer; $\mathrm{pH}$ was ser to 7.4 and the $\mathrm{NaCl}$ concentration was increased to $1.4 \mathrm{M}$. DNA was precipitated by the addition of 0.7 volume isopropanol, collected by centrifugation, washed twice with $70 \%$ ethanol and dried in vacuo. Before analysis, DNA was redissolved in water and quantified by spectrophotometry at $260 \mathrm{~nm}$. 


\section{Analysis of $\varepsilon d A$ and $\varepsilon d C$}

$\varepsilon \mathrm{dA}$ and $\varepsilon \mathrm{dC}$ were analyzed in DNA by immunoaffinity/32P-postlabelling. ${ }^{12}$ In brief, ca. $25 \mu \mathrm{g}$ of DNA was hydrolyzed to nucleotide 3'-monophosphates using micrococcal nuclease and spleen phosphodiesterase. Normal nucleotides were quantitated by high-performance liquid chromatography and adducts were enriched on immunoaffinity columns prepared from the monoclonal antibodies EM-A-1 ( $\varepsilon$ $\mathrm{dA}$ ) and EM-C-1 (EdC). The antibodies used in this study were provided by M. Rajewsky (Institute of Cell Biology, University of Essen, Essen, Germany). The adducts and the internal standard deoxyuridine 3'-monophosphate were labeled with $\left[\gamma^{32}\right.$ P]ATP $(>5000 \mathrm{Ci} / \mathrm{mmol})$ and $\mathrm{T} 4$ polynucleotide kinase (Amersham Buchler, Braunschweig, Germany and Pharmacia Biotech, Freiburg, Germany, respectively). Adducts were resolved on polyethyleneimine-TLC plates using twodirectional chromatography $[\mathrm{D} 1=1 \mathrm{M}$ aceric acid $(\mathrm{pH} 3.5), \mathrm{D} 2=$ saturated ammonium sulfate $(\mathrm{pH} 3.5)]$. After autoradiography, the adduct spots and the internal standard were marked, cut, and the radioactivity was measured in a liquid scintillation counter. The absolute adduct levels were quantitated using standards, and the relative adduct level per parent nucleorides was determined with the amount of deoxycytidine $(\mathrm{dC})$ and deoxyadenosine $(\mathrm{dA})$ obtained from highperformance liquid chromatography analysis of normal nucleotides obtained from the DNA digest. Typical chromatograms are shown in Figure 3.2.
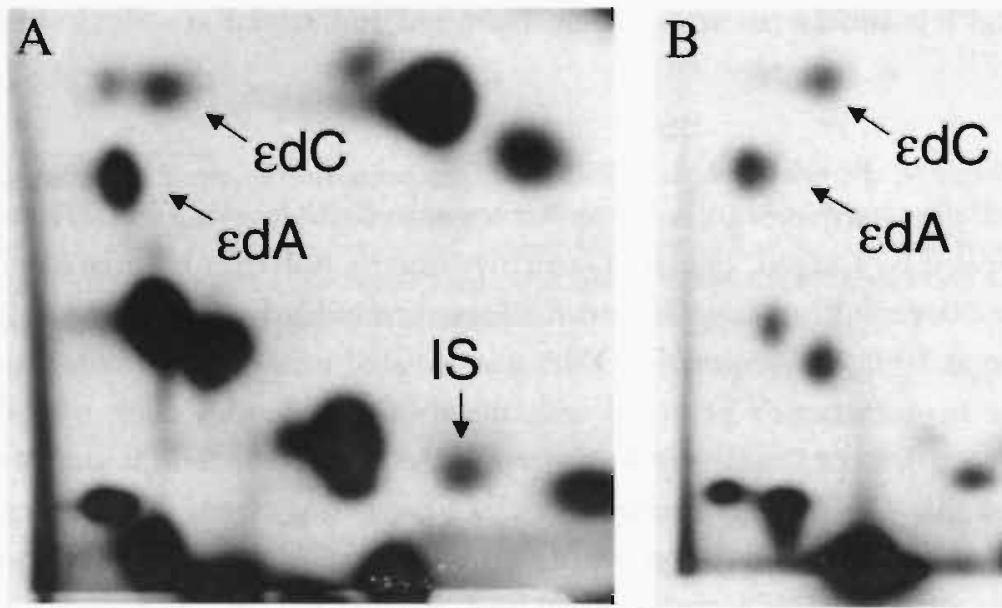

Figure 3.2 Adduct profiles after sp-postlabelling and thin layer chromatography of an aorta sample (panel $A$ ) and a standard mixture of $1, N^{\mathrm{k}}$-ethenodeoxyadenosine [EdA] and $3, N^{4}$-ethenodeoxycytidine $[\varepsilon \mathrm{dC}]($ Panel B). IS = internal standard (dUp) used for quantitation purposes. 


\section{Analysis of BPDE-DNA adducts}

Nuclease P1 enriched ${ }^{32} \mathrm{P}$-postlabelling analysis was performed to assess benzo[a]pyrene-diol-epoxide (BPDE)-DNA adduct levels in aorta and lung. ${ }^{13}$ Briefly, DNA was enzymatically digested and unmodified nucleotides were dephosphorylated by nuclease P1. Labelling was carried out with excess $\left[\gamma^{-32} \mathrm{P}\right]$ ATP and T4-polynucleotide kinase. 5'-Labeled adducts were resolved on polyethylenimine-cellulose TLC sheets (Merck, Darmstadt, Germany) using the solvents as described in ref. 13. In each experiment, 3 standards of $\left[{ }^{3} \mathrm{H}\right]$-BPDE modified DNA with known modification levels (1 per $10^{7}, 10^{8}$ and $10^{9}$ nucleotides) were run in parallel for quantification purposes. These standards were synthesized by incubations of calf-thymus DNA with [ $\left.{ }^{3} \mathrm{H}\right]-\mathrm{BPDE}$ (NCI, USA) and their modification levels were determined by ${ }^{3} \mathrm{H}$-scintillation counting. Quantification was performed by using a phosphor-imager (Molecular Dynamics ${ }^{\mathrm{TM}}$, Sunnyvale, CA, USA).

\section{Measurement of blood lipids}

Standard enzymatic techniques were used for the assessment of plasma lipid levels, automated on the Cobas Fara centrifugal analyzer (Hoffmann-La Roche, LTD, Basel, Switzerland). Total plasma cholesterol and high density lipoproteins (HDL) were measured using kit no. 07-3663-5 and no. 543004 (Hoffmann-La Roche), total glycerol using kit no 337-40A/337-10B (Sigma) and free glycerol was measured using kit no. 0148270 (Hoffmann-La Roche). Precipath (standardized serum) was used as standard. Low density lipoprotein (LDL) levels were calculated in $\mathrm{mmol} / \mathrm{L}$ using the formula: LDL cholesterol $=$ total cholesterol - (triglycerides / 2.2) - HDL cholesterol.

\section{Statistical Analysis}

The results are presented as mean $\pm S D$. Differences in erheno-DNA adduct levels and plasma lipid levels berween B[a]P treated mice and vehicle treated mice were compared by the non-paramerric Mann-Whitney $U$ test (no tied ranks present in the data). Relationships berween various parameters were studied using simple regression analysis. $P<0.05$ was considered statistically significant.

\section{Results}

Effect of diet and B[a]P on blood lipids and body weight

Plasma levels of HDL, LDL, total cholesterol and triglycerides were found to be 
slightly increased in apoE-KO mice that received a high fat diet as compared to those on a low fat diet (Table 3.1). Treatment of these mice with a single oral dose of B[a]P ( $5 \mathrm{mg}$ per $\mathrm{kg}$ bodyweight) and assessment of serum lipid levels 4 days after treatment, showed a significant reduction of LDL, and a concomitant increase of HDL-levels (Table 3.1). Consequently, the overall LDL/HDL ratio was 3-fold decreased from $47.1 \pm 21.4$ to $15.9 \pm 13.9(P=0.001)$. Animals on a high fat diet gained more weight during the experiment as compared to the mice on a low fat diet and therefore weighed approximately $20 \%$ more than those on a low fat diet at the time of exposure to B[a]P (Table 3.1).

Table 3.1 Effect of B[a]P exposure and type of diet on plasma levels of low density lipoproteins (LDL), high density lipoproteins (HDL), triglycerides and the formation of DNA adducts in mouse aorta

\begin{tabular}{lcccc}
\hline & \multicolumn{2}{c}{ Not exposed to B[a]P, $(n=5)$} & \multicolumn{2}{c}{ Exposed to B[a]P, $(n=5)$} \\
\cline { 2 - 5 } & Low fat diet & High fat diet & Low fat diet & High fat diet \\
\hline Body weight $(\mathrm{g})$ & & & & \\
Before experiment & $22.7 \pm 1.0$ & $25.0 \pm 0.9$ & $23.9 \pm 0.8$ & $25.4 \pm 1.0$ \\
After experiment & $22.6 \pm 1.5$ & $27.4 \pm 2.4$ & $23.8 \pm 1.0$ & $28.1 \pm 1.3$ \\
Weight gain & $-0.1 \pm 0.7$ & $2.4 \pm 2.1$ & $-0.1 \pm 0.8$ & $2.7 \pm 0.7$ \\
Lipoprotein levels (mmol/L) & & & & \\
LDL & $12.6 \pm 2.6$ & $14.2 \pm 5.3$ & $6.6 \pm 2.4^{*}$ & $14.1 \pm 3.1$ \\
HDL & $0.2 \pm 0.1$ & $0.6 \pm 0.4$ & $0.6 \pm 0.6^{* *}$ & $2.5 \pm 1.9^{* *}$ \\
Triglycerides & $1.0 \pm 0.2$ & $1.2 \pm 0.5$ & $1.4 \pm 0.4$ & $0.8 \pm 0.1$ \\
LDL/HDL & $54.7 \pm 12.2$ & $39.5 \pm 27.2$ & $21.3 \pm 16.1^{*}$ & $9.1 \pm 8.0^{* *}$ \\
DNA adducts (per 10 parent nucicotides) & & & \\
EdA & $2.9 \pm 1.6$ & $3.9 \pm 0.8$ & $7.3 \pm 4.4^{* *}$ & $8.8 \pm 4.7^{*}$ \\
EdC & $6.3 \pm 3.9$ & $5.9 \pm 3.3$ & $4.9 \pm 2.3$ & $6.5 \pm 3.6^{*}$ \\
BPDE-DNA & ND & ND & $10.8 \pm 3.3$ & $13.1 \pm 3.2$ \\
\hline
\end{tabular}

$\because \mathrm{P}<0.05 *: \mathrm{P}<0.07$ as compared to unexposed controls on same diet.

ND: Not detectable

\#: Adduet level expressed as adduers per $10^{8}$ total nucleotides.

\section{Effect of diet and B[a]P on etheno-DNA adduct formation in aorta}

Low or high far diets for a period of 25 days did not differently affect adduct levels (expressed per $10^{8}$ parent nucleotides): $\varepsilon \mathrm{dA}, 2.9 \pm 1.6$ and $3.9 \pm 0.8$ adducts, and $\varepsilon \mathrm{dC}, 6.3 \pm 3.9$ and $5.9 \pm 3.3$ adducts, respectively in aorta of apoE-KO mice. In control animals, mean $\varepsilon \mathrm{d} A$ levels were approx. 2-fold lower than $\varepsilon \mathrm{dC}$ levels $(P=$ $0.07)$, and both DNA adduct types were interrelated $(\mathrm{R}=0.62, P=0.04, n=10)$, 
suggesting similar pathways in their formation.

$\varepsilon \mathrm{dA}$ levels were significantly higher in animals which were exposed to $\mathrm{B}[\mathrm{a}] \mathrm{P}$ as compared to unexposed controls $(8.1 \pm 4.4$ and $3.4 \pm 2.1$, respectively, animals on low and high fat diet combined, $n=10$ per group, $P<0.05)$. Similar effects were observed in animals on low or high fat diets separately (Table 1). Levels of $\varepsilon \mathrm{dC}$ were unaffected by acute oral exposure to $\mathrm{B}[\mathrm{a}] \mathrm{P}$. As a result, there was no significant relationship between $\varepsilon \mathrm{dA}$ and $\varepsilon \mathrm{dC}$ levels in $\mathrm{B}[\mathrm{a}] \mathrm{P}$-exposed animals $(\mathrm{R}=0.33, P=0.34)$.

\section{Bulky adduct formation in aorta and lung}

BPDE-DNA adduct formation in apoE-KO mice on a normal lab chow was 3fold higher in aorta (10.8 \pm 1.4 BPDE-DNA adducts/ $10^{8}$ nucleotides) than in lung $(3.3 \pm 0.7, P<0.05)$. In animals kept on a high fat diet, DNA adduct levels were even $>6$-fold higher in aorta $(13.1 \pm 3.2)$ than in lung DNA $(2.1 \pm 0.5)$. A significant relationship was observed between BPDE-DNA adduct levels and levels of $\varepsilon \mathrm{dA}(\mathrm{R}=0.65, P=0.002)$, which was not found for $\varepsilon \mathrm{dC}(\mathrm{R}=0.07, P=$ 0.77). BPDE-DNA adducts were not detectable in lung and aorta of unexposed controls.
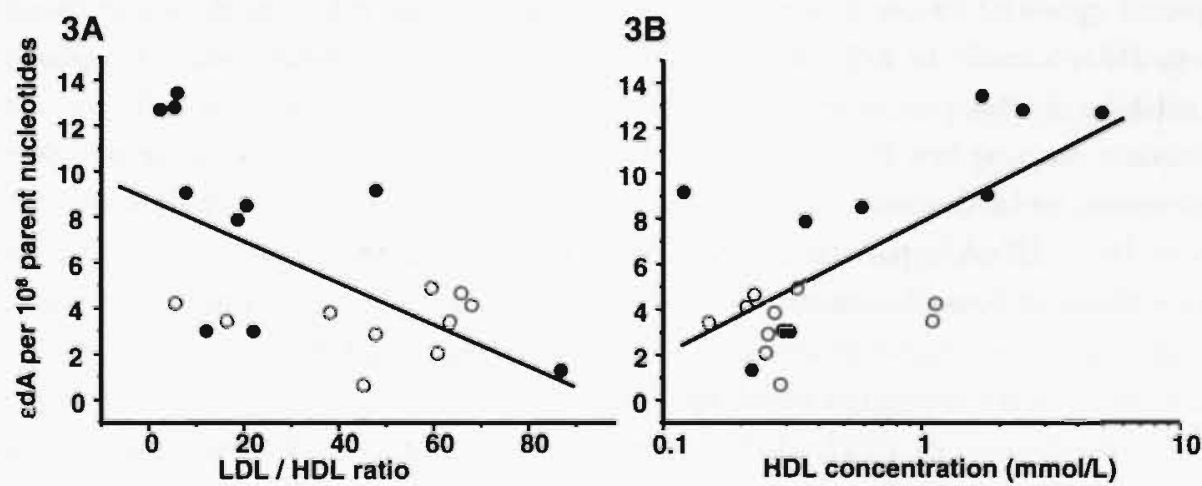

Figure 3.3 (A) Correlation between the LDL/HDL-ratio and levels of 1,N $\mathrm{K}_{-}$ ethenodeoxyadenosine $(\varepsilon d A)(R=-0.60, P=0.005, n=20)$. (B) Correlation between serum HDL-concentrations and levels of $\varepsilon \mathrm{dA}(\mathrm{R}=0.68, P=0.02, n=20)$.

Values of B[a]P-exposed animals are indicated as $(\bullet)$, and unexposed controls as (o).

\section{Relationship between etheno-DNA adducts with blood lipid levels}

LDL/HDL ratios decreased significantly and $\varepsilon \mathrm{dA}$ levels were concomitantly increased after treatment with B[a]P. As a result, an inverse relationship was observed between $\varepsilon \mathrm{dA}$ and the LDL/HDL ratio in B[a]P exposed animals $(\mathrm{R}=$ - 
$0.60, P=0.005$, Figure $3.3 \mathrm{~A}$ ), but not in unexposed controls. Further analysis revealed that this was predominantly due to a strong positive relation between $\varepsilon \mathrm{dA}$ and HDL concentrations $(\mathbb{R}=0.68, P=0.02$, Figure $3.3 \mathrm{~B})$. On the other hand, no such relationship was observed between $\varepsilon \mathrm{dA}$ and LDL levels. Serum lipid concentrations were not related to levels of $\varepsilon \mathrm{dC}$ in aorta of apo-KO mice (LDL, $\mathrm{R}=0.01, P=0.98$; HDL, $\mathrm{R}=0.39, P=0.09$ ).

\section{Discussion}

The well-studied environmental carcinogen $\mathrm{B}[\mathrm{a}] \mathrm{P}$ was found to enhance atherosclerotic plaque progression in experimental animals," but the mechanism by which B[a]P modulated the atherogenic process is not known. Since lipid peroxidation seems to play a predominant role in the aetiology of atherosclerosis, we hypothesized that $\mathrm{B}[\mathrm{a}] \mathrm{P}$ induces oxidative stress with subsequent lipid peroxidation in the vessel wall. Increased lipid peroxidation after exposure to $\mathrm{B}[\mathrm{a}] \mathrm{P}$ would result in an increased formation of etheno-DNA adducts in aorta, which are frequently applied as stable biomarkers for in vivo oxidative stress. ${ }^{7}$ This was indeed observed in the present study; the lipid peroxidation related DNA lesion $1, N^{6}-$ ethenodeoxyadenosine ( $\varepsilon \mathrm{d} A$ ) was found to be 2.5 fold increased in aorta of $\mathrm{B}[\mathrm{a}] \mathrm{P}$ exposed apoE-KO mice as compared to unexposed controls. On the other hand, no increased levels of $\varepsilon \mathrm{dC}$ were found in B[a]P-exposed mice, which is actually formed by similar pathways as compared with $\varepsilon d A$. Differences in DNA repair efficiency may explain this discrepancy; $\varepsilon \mathrm{dA}$ is repaired by 3-methyladenine DNA glycosylase, whereas $\varepsilon d C$ is repaired by a mismatch specific thymidine-DNA glycosylase. ${ }^{7}$ DNA repair processes were found to be up-regulated in aortas of hypercholesterolemic laboratory rodents, ${ }^{14}$ but no information is currently available on specific DNA repair processes and their dietary modulation (or upregulation due to oxidative stress) in aorta of apoE-KO mice.

Formation of BPDE-DNA adducts was found to be 3 (low fat diet) to 6 fold (high fat diet) higher in aorta as compated to lung, which is an important target organ for the genotoxicity of B[a]P. Next to the formation of BPDE-DNA adducts, $\mathrm{B}[\mathrm{a}] \mathrm{P}$ is metabolically converted into $\mathrm{B}[\mathrm{a}] \mathrm{P}-\mathrm{q}$ uinones, which can undergo redox-cycling to their corresponding $\mathrm{B}[\mathrm{a}] \mathrm{P}$-diols, producing superoxide and hydroxyl radicals by the Haber-Weiss and Fenton reactions. ${ }^{10}$ Superoxide and hydroxyl radicals can subsequently give rise to increased levels of oxidative stress and the LPO derived pro-mutagenic etheno-bridged base modifications. These data indicate that aorta is an additional biologically relevant target for B[a]P.

Although the formation of BPDE-DNA adduct levels in aorta as 
compared to lung was increased by a high fat diet, this type of diet did not alter etheno-DNA adduct levels. However, since we wanted to study the effect of B[a]P exposure on lipid peroxidation in the early phase of atherogenesis, the animals used in this study might have been too young and/or the feeding period too short to observe strong effects of diet on etheno-DNA adduct formation. Moreover, the high fat diet predominantly contained saturated fatty acids, which are much less susceptible for LPO than $\omega-6$ polyunsaturated fatty acids (PUFAs).

After $\mathrm{B}[\mathrm{a}] \mathrm{P}$ exposure, an increase of HDL levels and a concomitant decrease of serum LDL concentrations was found, which was also observed in human volunteers who consumed charcoal-grilled meat containing B[a]P.15 This effect of $\mathrm{B}[\mathrm{a}] \mathrm{P}$ on serum lipid levels was found to be due to the induction of hepatic cytochrome $\mathrm{P} 450 \mathrm{~s},{ }^{16}$ and was expected to be a beneficial change, because HDL may act as an antioxidant and thus may suppress oxidative stress in the vessel wall. However, this was not in agreement with the positive relation between $\varepsilon \mathrm{dA}$ and HDL levels as observed in the present study (Figure 3.3B), which in fact suggests that HDL acted as a pro-oxidant in this experimental model of environmentally induced atherosclerosis. HDL in the basal state is antiinflammatory and capable of destroying oxidized lipids that generate an inflammatory response. ${ }^{17}$ However, HDL in ApoE-KO mice can be altered and become pro-inflammatory, ${ }^{18}$ which has also been observed during the acute phase responses after bacterial or viral infections, ${ }^{19}$ and exposure to cigarette smoke. ${ }^{20}$ Changes in the functionality of HDL, rather than changes of plasma HDL levels determine the anti-atherogenicity of HDL. Acute exposure to $\mathrm{B}[\mathrm{a}] \mathrm{P}$ may induce a remodeling of $\mathrm{HDL}$ to its pro-inflammatory state. Furthermore, B[a]P is predominantly transported in rodents by $\mathrm{HDL}_{,}{ }^{2 i}$ and may thus be specifically taken up by HDL. from the vessel wall during the reverse cholesterol transport. HDL, was positively associated with $\varepsilon d A$ levels in animals exposed to B[a]P, which is consistent with the hypothesis that cigarette smoke constituents modify serum HDL such that there is an increased risk of coronary artery disease due to a diminished capacity to protect lipoproteins from oxidative stress.22 More studies are necessary to elucidate the exact role of $\mathrm{B}[\mathrm{a}] \mathrm{P}$ or other tobacco smoke carcinogens in modulating the protective capacity of HDL against reacrive lipid peroxides.

DNA damage remains a poorly examined field in atheroslerosis, but our current findings show that the analysis of oxidatively damaged DNA bases may provide relevant and stable biomarkers for in vivo oxidative stress in human atherosclerosis or animal models. The covalent interacrion of reactive carcinogenic metabolites with DNA (i.e. DNA adducts) is thought to be a critical initial step in chemically induced carcinogenesis, and DNA adduct measurements are therefore 
frequently used as biomarkers for exposure to carcinogenic compounds. High levels of DNA adducts were also detected in human aorta, ${ }^{23}$ heart tissue of patients with atherosclerotic plaques, ${ }^{24}$ and in cardiovascular tissue of animal models, ${ }^{25}$ indicating that the vascular system may represent a relevant target organ. The etiological role of these DNA modifications in atherosclerosis, however, remains to be demonstrated. We conclude that B[a]P exposure results in increased lipid peroxidation in the vessel wall, which may explain the promoting effect of B[a]P on atherogenesis. 


\section{References}

1. Ross R: The pathogenesis of atherosclerosis: a perspective for the 1990s. Nature 1993, 362:801-809.

2. Hansen ES: Shared risk factors for cancer and atherosclerosis: A review of the epidemiological evidence. Mutat. Res 1990, 239:163-179.

3. McCaffrey TA, Du B, Fu C, Bray PJ, Sanborn TA, Deutsch E, Tarazona N, Shanovitch A, Newman G, Patterson C, Bush HL: The expression of TGF-beta receptors in human atheriosclerosis: evidence for acquired resistance to apoptosis due to receptor imbalance. J. Mol, Cell Cardiol, 1999, 31:1627-1642.

4. Bridges BA, Bowyer DE, Hansen ES, Penn $A$, Wakabayashi K: Report of ICPEMC Subcommittee $7 / 1$. The possible involvement of somatic mutations in the development of atherosclerotic plaques. Mutat. Res. 1990, 239:143-187.

5. De Flora S, Izzotti A, Walsh D, Degan P, Petrilli GL, Lewtas J: Molecular epidemiology of atherosclerosis. FASEB J.1990, 11:1021-1031.

6. El Ghissassi F, Barbin $\mathrm{A}$, Nair J, Bartsch H: Formation of $1, N^{6}$-ethenoadenine and $3, N^{4}$ ethenocytosine by lipid peroxidation products and nucleic acid bases. Chem. Res. Taxicol. $1995,8: 278-283$.

7. Bartsch H, Barbin A, Marion Mj, Nair J, Guichard Y: Formation, detection and role in carcinogenesis of etheno-bases in DNA. Drug Metab. Rev. 1994, 26:349-371.

8. Davignon J, Cohn JS, Mabile L, Bernier L: Apolipoprotein E and atherosclerosis: insights from animal and human studies. Clinica Chimica Acta 1999, 286:115-143.

9. Palinski W, Ord VA, Plump AS, Breslow JL, Steinberg D, Witztum JL: ApoE-deficient mice are a model of lipoprotein oxidation in atherosclerosis. Demonstration of oxidationspecific epitopes in lesions and high titers of autoantibodies to malondialdehyde-lysine in serum. Arterioscler Thromb 1994, 14:605-616.

10. Kim HS, Kwack SJ, Lee BM: Lipid peroxidation, antioxidant enzymes, and benzo[a|pyrene-quinones in the blood of rats treated with benzo[a]pyrene. Chemico Biol Interact 2000, 127:139-150.

11. Curfs DM, Lutgens E, Gijbels MJ, Kockx MM, Daemen Mj, van Schooten F): Chronic exposure to the carcinogenic compound benzo[alpyrene induces larger and phenotypically different atherosclerotic plaques in apoE-knockout mice. Am J Patbol 2004, 164:101-108.

12. Nair J, Barbin A, Guichard X, Bartsch H: 1,N6-ethenodeoxyadenosine and 3,N4ethenodeoxycytine in liver DNA from humans and untreated rodents detected by immunoaffinity/32P-postlabelling. Cancinogenesis 1995, 16:613-617.

13. Godschalk RW, Maas LM, Van Zandwijk N, van't Veer Lj, Breedijk A, Borm PJ, Verhaert J. Kleinjans JC, van Schooren F]: Differences in aromatic-DNA adduct levels between alveolar macrophages and subpopulations of white blood cells from smokers. Cancinogenesis 1998, 19:819-825.

14. Martinet W, Knaapen MW, De Meyer GR, Herman AG, Kockx MM: Oxidative DNA damage and repair in experimental atherosclerosis are reversed by dietary lipid lowering. Ginulation Research 2001. 88:733-739.

15. Heller RF, Hartley RM, Lewis B: The effect on blood lipids of eating charcoal-grilled meat. Atberosclerosis 1983, 48:185-192.

16. Luoma PV: Microsomal enzyme induction, lipoproteins and atherosclerosis. Pbarmacol Toxicol 1988, 62:243-249.

17. Tedgui A, Mallat Z: Anti-inflammatory mechanisms in the vascular wall Cin Res 2001, 88:877-887.

18. Navab M, Hama-Levy S, Van Lenten BJ, Fonarow GC, Cardinez CJ, Castellani LW, Brennan ML, Lusis AJ, Fogelman AM, La Du BN: Mildly oxidized LDL induces an increased apolipoprotein J/paraoxonase ratio. J Clin Inest 1997, 99:2005-2019.

19. Van Lenten BJ, Hama SY, de Beer FC, Stafforini DM, MeIntyre TM, Prescott SM, La Du BN, Fogelman AM, Navab M: Anti-inflammatory HDL becomes pro-inflammatory during 
the acute phase response. Loss of protective effect of HDL against LDL oxidation in aortic wall cell cocultures. J Clin Inest 1995, 96:2758-2767.

20. Watson AD, Berliner JA, Hama SY, La Du BN, Faull KF, Fogelman AM, Navab M: Protective effect of high density lipoprotein associated paraoxonase. Inhibition of the biological activity of minimally oxidized low density lipoprotein. J Chin Intest 1995, 96:28822891.

21. Vost A, Maclean N: Hydrocarbon transport in chylomicrons and high-density lipoproteins in rat. Lipids 1984, 19:423-435.

22. Nishio E, Watanabe Y: Cigaretre smoke extract inhibits plasma paraoxonase activity by modification of the enzyme's free thiol. Biochem Bioplys Res Commun 1997, 236:289-293.

23. Binkova B, Strejc P, Boubelik O, Stavkova Z, Chvatalova I, Sram RJ: DNA adducts and human atherosclerotic lesions. Int J Hgg Environ Health 2001, 204:49-54.

24. Van Schooten FJ, Hirvonen A, Maas LM, De Mol BA, Kleinjans JCS, Durrer JD: Putacive susceptibility markers of coronary artery disease: association between VDR genotype, smoking, and aromatic DNA adduct levels in human right atrial tissue. FASEB J 1998, 12:1409-1417.

25. Izzoti A, Camoirano A, Cartiglia C, Tampa E, De Flora S: Formation of DNA adducts in the aorta of smoke-exposed rats, and modulation by chemopreventive agents. Mutat Res 2001, 494:97-106. 




\section{Chapter 4}

\section{Chronic exposure to the carcinogenic compound benzo[a]pyrene induces larger and phenotypically different atherosclerotic plaques in ApoE- knockout mice}

Daniëlle M.J. Curfs, Esther Lutgens, Marion J.J. Gijbels, Mark M. Kockx, Mat J.A.P. Daemen, Frederik J. van Schooten 


\section{Abstract}

Benzo[a]pyrene $(\mathrm{B}[\mathrm{a}] \mathrm{P})$ is a polycyclic aromatic hydrocarbon with atherogenic and carcinogenic properties. The role of $\mathrm{B}[\mathrm{a}] \mathrm{P}$ in carcinogenesis is well established, and thought to exert via enzymatic activation into reactive metabolites, which are capable of binding to the DNA leading to uncontrolled proliferation. However, the mechanism underlying the atherogenic properties of $\mathrm{B}[\mathrm{a}] \mathrm{P}$ is still unclear. Therefore, the effects of chronic $\mathrm{B}[\mathrm{a}] \mathrm{P}$ exposure on atherosclerotic plaque development in apolipoprotein $\mathrm{E}$ knockout (apoE-KO) mice were studied. ApoE$\mathrm{KO}$ mice were orally treated with $5 \mathrm{mg} / \mathrm{kg}$ bw B[a]P once per week for 12 or 24 consecutive weeks. Levels of reactive B[a]P metabolites in the arterial tree (from the aortic arch until the iliac artery bifurcations) were high as shown by the level of $\mathrm{B}$ [a]P DNA-binding products measured in DNA isolated from the entire aorta (38.9 \pm 4.8 adducts $/ 10^{8}$ nucl.). Analysis of atherosclerotic lesions in the aortic arch showed no influence of $\mathrm{B}[\mathrm{a}] \mathrm{P}$ on location or number of lesions. Moreover, no increased levels of $p 53$ nuclear protein accumulation or cell proliferation, as detected by immunohistochemistry, were seen in the plaques of the B[a]P-exposed animals. However, the effects of $\mathrm{B}[\mathrm{a}] \mathrm{P}$ on advanced lesions were obvious: advanced plaques were larger, more prone to lipid core development and plaque layering at both 12 and 24 weeks $(P<0.05)$. In the B[a]P-exposed animals advanced plaques contained more $\mathrm{T}$-lymphocytes and macrophages than in the control animals at both endpoints $(P<0.05)$. These data suggest that $\mathrm{B}[\mathrm{a}] \mathrm{P}$ does not initiate atherosclerosis in apoE-KO mice, but accelerates the progression of atherosclerotic plaques via a local inflammatory response. 


\section{Introduction}

It is demonstrated that chemicals such as polycyclic aromatic hydrocarbons (PAHs) play a role in both cancer and cardiovascular diseases. ${ }^{1}$ PAHs, products of the incomplete combustion of organic materials, are a large group of structurally related lipophilic compounds with two or more condensed benzene rings. They are abundantly present in, for example, cigarette smoke and charcoal broiled and smoked foods. The general population is exposed to PAHs on a daily basis, mainly via ingestion of contaminated foods and inhalation of polluted air. ${ }^{2}$ Benzola]pyrene $(\mathrm{B}[\mathrm{a}] \mathrm{P})$, a model $\mathrm{PAH}$, is metabolized via cytochrome $\mathrm{P} 450 \mathrm{~s}$ into reactive dihydrodiol epoxide derivates, eg, B[a]P-7,8-dihydrodiol-9,10-epoxide (BPDE), which are capable of binding covalently to the DNA. ${ }^{3}$ In the carcinogenic process, formation of these so-called BPDE-DNA adducts is considered to be a crucial initial step leading to mutations and subsequently to uncontrolled cell growth and tumor formation. ${ }^{4}$ Although $\mathrm{B}[\mathrm{a}] \mathrm{P}$ has been shown to influence atherosclerosis in animal models, ${ }^{5}$ the exact underlying mechanism of chemical atherogenesis is still not elucidated.

In the 1970 s initial studies from Benditt and Benditt ${ }^{6}$ showed that human atherosclerotic plaques had a monoclonal origin. At the same time, the first animal experiments proved the involvement of chemical carcinogens in atherosclerotic plaque development? Finally, in 1986 it was shown that DNA extracted from human coronary artery plaques were capable of transforming NIH3T3 cells. ${ }^{8}$ These consecutive observations have lead to the suggestion that atherosclerotic plaques are presumably benign smooth muscle cell tumors that develop according to an initiation-promotion-progression protocol. More recently, animal studies have shown that the aorta is a target for carcinogen-induced DNA damage." Similarly in humans exposed to environmental carcinogens, arterial DNA damage is high and related to atherogenic risk factors. ${ }^{10-12}$ Moreover, several human studies showed that DNA damage and repair seem to be associated with atherosclerosis. ${ }^{13,14}$ However, although it is clear that carcinogens cause substantial DNA damage in the vessel wall and are able to promote atherosclerotic plaque growth, carcinogen-induced iniriation of new plaques has hardly ever been observed. This suggests that the processes involved in chemical carcinogenesis (ie, DNA damage, mutagenesis, proliferation) cannot simply explain the mechanisms underlying chemical atherogenesis. Still, research into chemical atherogenesis has kept its focus mainly on arterial DNA damage as an iniriaring step for subsequent smooth muscle cell proliferation, akin a benign rumor. ${ }^{10,11}$

With the development of the apoE-KO mouse, a transgenic animal model was created in which diet-independent atherosclerotic lesions develop that have 
striking similarities to the human disease. ${ }^{15}$ This model proved very useful in studying biochemical and cellular events leading to several aspects of atherosclerosis like initiation, progression, growth arrest and regression. ${ }^{16}$ In the present study this mouse model was applied to gain more knowledge on the effects of chronic $\mathrm{B}[\mathrm{a}] \mathrm{P}$ exposure on plaque formation and differentiation. The specific aim of this study was to obtain new insights in the pathways involved in chemical atherogenesis. Therefore, rather than focusing only on DNA damage and plaque area, extensive immunohistochemistry was used to explore differences in plaque phenotype and composition more closely.

\section{Materials and Methods}

\section{Animal Treatment}

Male apoE-KO mice were purchased from IFFA CREDO S.A. (Charles River Co,, Lyon, France) and fed a normal mouse chow (SRM-A; Hope Farms, Woerden, The Netherlands).

B[a]P (B1760; Sigma, St. Loius, MO, USA) was initially dissolved in acetone and added to tricaprylin (103104; ICN, Costa Mesa, CA, USA). Evaporation of acetone resulted in a homogenous solution of $0.5 \mathrm{mg} B[\mathrm{a}] \mathrm{P} / \mathrm{ml}$ tricaprylin. At 5 weeks of age, animals $(17.2 \pm 1.8 \mathrm{~g})$ were orally treated with 5 $\mathrm{mg} / \mathrm{kg}$ bw B $[\mathrm{a}] \mathrm{P}$ or vehicle, after an overnight fasting period. This procedure was repeated once per week for $12(n=31)$ and $24(n=19)$ consecutive weeks. By weighing the animals weekly, growth was monitored. To confirm that $\mathrm{B}[\mathrm{a}] \mathrm{P}$ was capable of inducing vascular DNA damage prior to plaque formation, 4 wild type C57BL/ 6 mice were treated once orally with $25 \mathrm{mg} / \mathrm{kg}$ bw B[a]P. Animals were killed after 4 days and DNA-adducts were measured by ${ }^{32} \mathrm{P}$-postlabeling.

\section{Tissue Handling}

On euthanasia, $-0.5 \mathrm{ml}$ blood was drawn from the inferior caval vein. The arterial tree was perfused in situ for 3 minutes with $0.9 \% \mathrm{NaCl}$ containing $20 \%$ nitroprusside $(3$ minutes) and subsequently with $1 \%$ phosphate-buffered paraformaldehyde ( $\mathrm{pH} 7.4 ; 3$ minutes) via a catheter in the left ventricular apex. The arterial tree was excised and fixed overnight in 1\% phosphate-buffered paraformaldehyde ( $\mathrm{pH}$ 7.4). The aortic arch (including the brachiocephalic trunk, left carotid artery and left subclavian artery), thoracic and abdominal aorta (TA and AA respectively) were longitudinally embedded in paraffin, and subsequently serial $4-\mu \mathrm{m}$ sections were cut. Pieces of lung and liver tissue of all animals $(n=50)$ as well as the entire aorta (aortic arch and the descending aorta until the iliac artery 
bifurcations) of 22 animals from the 12 weeks group (11 B[a]P versus 11 controls) were used for DNA adduct measurement.

Furthermore, $>20$ organs were investigated macroscopically for abnormalities. Hematoxylin and eosin (H\&E)-stained sections of lung, liver and spleen were also microscopically evaluated.

\section{Lipid measurement}

Lipid levels were measured using standard enzymatic techniques, automated on the Cobas Fara centrifugal analyzer (Hoffmann-La Roche, Basel, Switzerland). Total plasma cholesterol and HDL were measured using kit no. 0736635 and no. 543004 (Hoffmann-La Roche), total glycerol using kit no 337-40A/337-10B (Sigma) and free glycerol using kit no. 0148270 (Hoffmann-La Roche). Precipath (standardized serum) was used as an internal standard. LDL was calculated using the formula: LDL cholesterol $(\mathrm{mmol} / \mathrm{L})=$ total cholesterol $-($ triglycerides $/ 2.2)-$ high-density lipoprotein cholesterol

\section{DNA isolation and ${ }^{32} P$-postlabeling}

DNA was isolated from lung, liver and aorta using a traditional phenol extraction procedure and dissolved in $2 \mathrm{mmol} / \mathrm{L}$ Tris $(2 \mathrm{mg} / \mathrm{ml}) .{ }^{17}$

Subsequently, $10 \mu \mathrm{g}$ DNA was digested into nucleotide monophosphates and treated with nuclease P1 for 40 minutes at $37^{\circ} \mathrm{C}$. Then, nucleotides were $5^{\prime}-$ labeled with ${ }^{32} \mathrm{P}$ using T4-polynucleotide kinase $(5.0 \mathrm{U})$ for 30 minutes at $37^{\circ} \mathrm{C}$. Radiolabeled adduct nucleotide biphosphates were separated by chromatography on polyethyleneimine (PEI)-cellulose sheets (Macherey Nagel, Düren, Germany) using solvents as described previously. ${ }^{17}$ In each experiment, 2 standards of [3H]BPDE modified DNA with known modification levels $\left(1\right.$ per $10^{7}, 10^{8}$ nucleotides) were included. Adduct quantification, by means of phosphor-imaging technology (Molecular Dynamics, Sunnyvale, CA, USA), was performed by calibrating towards the BPDE-DNA adduct standards.

\section{Histological and morphometrical analysis}

Of the aortic arch, the thoracic and abdominal aorta, four H\&E-stained sections, each separated by $20 \mu \mathrm{m}$, were used for histological analysis. Lesions were classified as initial or advanced based on the guidelines given by the American Heart Association. ${ }^{18}$ The absence or presence of a lipid core and the cell density (number of cells per $\mu \mathrm{m}^{2}$ ) of the plaques were also determined. For morphometrical analysis, four sections consecutive to the H\&E-stained sections, were stained according to Lawson (a modified elastica von Giesson staining). Sirius Red staining was performed for the detection of collagen. The relative collagen 
content was calculated by dividing the Sirius Red-positive plaque area by the total plaque area. Morphometrical parameters such as plaque area, lipid core area and plaque layering were measured using a computerized morphometry system (Quantimet 570; Leica). ${ }^{19}$

\section{Immunobistocbemical analysis}

Several immunohistochemical markers (cell proliferation, DNA repair and apoptosis) generally used in cancer biology were applied on aortic sections. Cell proliferation was detected with the ZYMED PCNA staining kit (ZYMED Laboratories Inc., San Francisco, CA, USA) and p53 nuclear protein accumulation by using the antibody CM5 (1:500 Novocastra Laboratories Ltd., Newcastle-uponTyne, UK). TUNEL staining (using the ApopTag kit; Oncor, Gaithersburg, MD, USA) for the detection of apoptotic cells was performed in the lab of Dr. M. Kockx (Antwerp, Belgium).

Moreover, immunohistochemical techniques were applied to classify specific cell types in the atherosclerotic plaques; smooth muscle cells were stained using an $\alpha$-smooth muscle actin antibody (ASMA FTT, 1:3000, Sigma F-3777); Tcells were labeled with anti-CD3 (1:200, A0452; DAKO, Glostrup, Denmark) and macrophages with Mac 3 (1:30; Pharmingen, San Jose, CA, USA). Factor VIII (1:2000; Eurodiagnostics, Malmö, Sweden) was used for the detection of endothelial cells. Quantification of all immunohistochemical stainings was performed by counting the respective positive stained cells per plaque divided by the total number of cells in the plaque.

\section{Statistical analysis}

Results are presented as mean \pm SEM. All plaque parameters as well as DNA adduct levels and plasma lipid levels were compared by a non-parametric MannWhimey $U$-test. $P<0.05$ was considered statistically significant. Two independent observers who were blinded for the exposure treatment performed the analyses. Inter- and intra-observer variation was $<10 \%$.

\section{Results}

\section{General}

Treatment with B[a]P resulted in growth retardation of the mice at both 12 and 24 weeks $(P<0.01, n=31$ and $P<0.01, n=19$ respectively; Table 4.1$)$. Macroscopic and microscopic evaluations of internal organs showed no tumor development or signs of inflammation in B[a]P-exposed and control mice (data not shown). 
Table 4.1 Weight gain, DNA adducts and lipoprotein levels

\begin{tabular}{|c|c|c|c|c|}
\hline & \multicolumn{2}{|c|}{12 weeks } & \multicolumn{2}{|c|}{24 weeks } \\
\hline & Control & $\mathrm{B}[\mathrm{a}] \mathrm{P}$ & Control & $\mathrm{B}[\mathrm{a}] \mathrm{P}$ \\
\hline Weight gain & $(n=15)$ & $(n=16)$ & $(n=9)$ & $(n=10)$ \\
\hline (g) & $11.3 \pm 0.6$ & $9.8 \pm 0.69$ & $13.9 \pm 0.3$ & $10.7 \pm 0.41$ \\
\hline DNA adducts & $(n=15)$ & $(n=16)$ & $(n=9)$ & $(n=10)$ \\
\hline \multicolumn{5}{|l|}{ (per $10^{8}$ nucleotides) } \\
\hline Aorta & $<0.018$ & $34.6 \pm 2.8^{\circ}$ & $<0.01$ & $-\infty$ \\
\hline Lung & $<0.01$ & $15.8 \pm 1.6^{\circ}$ & $<0.01$ & $16.1 \pm 1.0^{\circ}$ \\
\hline Liver & $<0.01$ & $5.2 \pm 0.3^{\circ}$ & $<0.01$ & $5.5 \pm 0.5$ \\
\hline Lipoprotein levels & $(n=9)$ & $(n=9)$ & $(n=9)$ & $(n=8)$ \\
\hline \multicolumn{5}{|l|}{$(\mathrm{mmol} / \mathrm{L})$} \\
\hline Total cholesterol & $9.5 \pm 0.7 \ddagger$ & $11.3 \pm 0.6^{\circ} \dagger$ & $11.4 \pm 0.5$ & $9.5 \pm 0.5 t$ \\
\hline Total glycerol & $0.8 \pm 0.04 \ddagger$ & $0.7 \pm 0.06 t$ & $1.4 \pm 0.1$ & $1.5 \pm 0.08$ \\
\hline HDL cholesterol & $0.2 \pm 0.06$ & $0.2 \pm 0.01$ & $0.3 \pm 0.03$ & $0.1 \pm 0.03$ \\
\hline Free glycerol & $0.4 \pm 0.02$ & $0.3 \pm 0.02$ & $0.3 \pm 0.06$ & $0.2 \pm 0.05$ \\
\hline LDL cholesterol & $9.0 \pm 0.7 \neq$ & $10.9 \pm 0.6^{\circ} \mathrm{t}$ & $10.6 \pm 0.5$ & $8.8 \pm 0.5^{\prime}$ \\
\hline
\end{tabular}

Values are mean \pm SEM. ${ }^{\infty}$ No arterial tissue available for DNA-adduct measurement.

$P<0.01$ verwus control group; ${ }^{*} P \leq 0.05$ versus control group; $\uparrow P \leq 0.05$ wrsus $\mathrm{B}[\mathrm{a}] \mathrm{P}$ group 24 wecks; $₫ P \leq$ 0.05 versus control 24 weeks; $\varsigma_{n}=11$.

\section{Plasma cholesterol and glycerol levels}

$\mathrm{B}[\mathrm{a}] \mathrm{P}$ treatment did not affect total glycerol, high-density lipoprotein cholesterol and free glycerol levels at both time points (Table 4.1). The influence of B[a]P on total cholesterol and low-density lipoprotein cholesterol was nor consistent: total cholesterol and concomitant low-density lipoprotein cholesterol levels were raised after 12 weeks of $\mathrm{B}[\mathrm{a}] \mathrm{P}$ exposure $(P<0.05$ wrsus controls), but lowered after 24 weeks of $\mathrm{B}[\mathrm{a}] \mathrm{P}$ exposure $(P<0.05$ werm controls). Total glycerol levels increased with age regardless of $B[a] P$ treatment.

\section{DNA adducts}

In aorta, lung and liver of the B[a]P-exposed animals the predominant adduct spot co-migrated with the BPDE-DNA-adduct standard (Figure 4.1). In lung and liver minor additional adduct spots were observed. DNA adduct quantification was performed based on the major adduct spot which co-migrated with the BPDEDNA-adduct standards. Inclusion of the minor additional adduct spots did not change the results significantly. After 12 weeks of exposure, adduct levels were ranked aorta $>$ lung $>$ liver (Table 4.1). At 24 weeks, no DNA-adducts were measured in the aorta since all aortic segments were used for histological purposes. 
However, DNA-adduct levels were determined in lung and liver and were comparable with the adduct levels found after 12 weeks of exposure. In the pilot study in which wild-type C57Bl6 mice were treated acutely with B[a]P, DNAadduct distribution was comparable to the 12 and 24 weeks study in apoE-KO mouse. High adduct levels were found in aorta $\left(16.0 \pm 1.1\right.$ adducts $/ 10^{8}$ nucleotides) and lung (14.5 \pm 0.8 adducts $/ 10^{8}$ nucleotides) and lower levels were found in the liver $\left(6.0 \pm 0.6\right.$ adducts $/ 10^{8}$ nucleotides $)$.

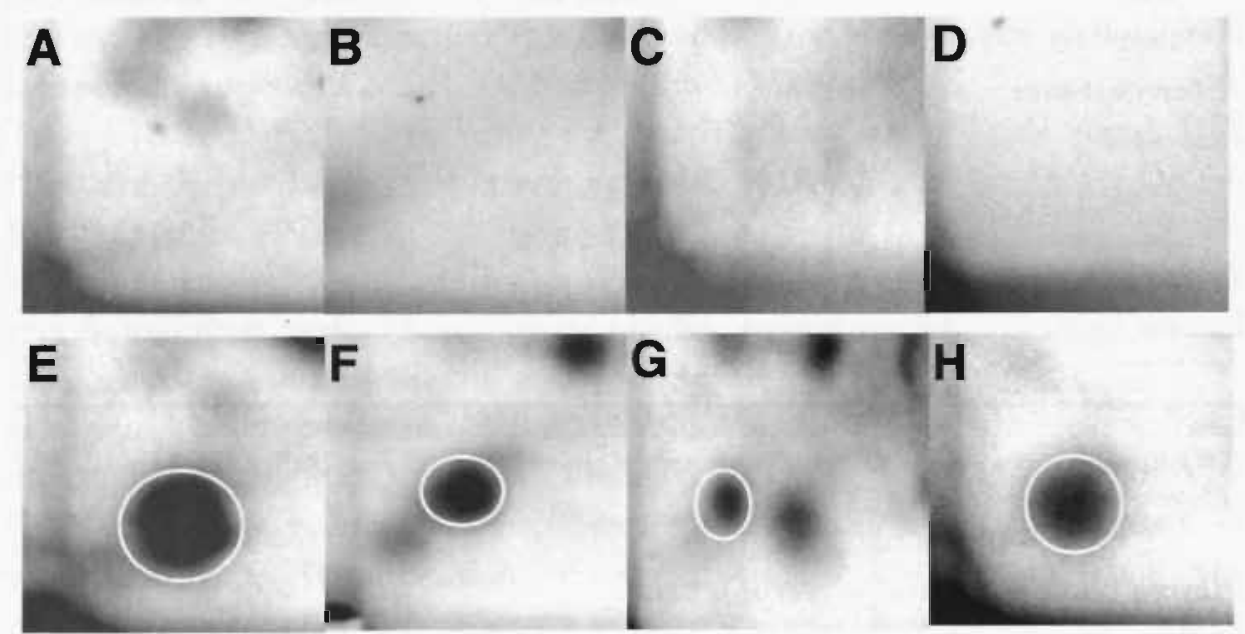

Figure 4.1 DNA-adduct profiles in apoE-knockout mice after 12 weeks of chronic B[a]P exposure.

Top row: chromatograms of aorta, lung and liver (A, B, and C, respectively) of control animals. Botrom row: Resulis of aorta, lung and liver (E, F, and $\mathbf{G}$, respectively) of $\mathrm{B}$ [a]P-exposed animals. $\mathbf{D}$ and $\mathbf{H}$ : MQ sample and a BPDE-DNA adduct standard (1 adduct per $10^{7}$ nucicotides), respectively. Differences in chromatography are because of interassay variations. In the B!a]P-treated mice a ciear DNA-adduct spot was found which migrated at the same position as the BPDE-DNA adduct standard (as indicated by the circles). Addinional spots were not used for quantification purposes.

\section{Plaque characteristics}

\section{Plaque burden}

Afrer 12 weeks, 24 lesions in the aortic arch of $\mathrm{B}[\mathrm{a}] \mathrm{P}$ mice $(n=5)$ and 14 lesions in controls $(n=4)$ were analyzed. After 24 weeks, analysis included 45 lesions in the aortic arch of $\mathrm{B}[\mathrm{a}] \mathrm{P}$-treated mice $(n=10)$ and 41 lesions of the control group $(n=$ 9). In both $\mathrm{B}[\mathrm{a}] \mathrm{P}$-exposed and control animals lesions were mainly present in the inner curve of the aortic arch and its main branchpoints the brachiocephalic trunk, the left common carotid artery and left subclavian artery (Figure $4.2 \mathrm{~A}$ and B). After 12 weeks, all mice had developed mild atherosclerosis with predominantly initial 
lesions, but after 24 weeks all animals exhibited severe atherosclerosis characterized by a high number of advanced lesions and large lesion areas. There were no differences in location and number of lesions per arch between groups at both time points (Figure 4.3A). Initial lesion area per arch was significantly smaller than the advanced lesion area within $\mathrm{B}[\mathrm{a}] \mathrm{P}$ and control animals (Figure 4.3B; $P<$ 0.01). Advanced lesions occupied a significant larger area per aorric arch in B[a]P animals than in controls at both endpoints (Figure 4.3B; $P<0.05$ ).

\section{Plaque initiation}

Because TA and AA are less sensitive to spontaneous plaque development, we used them to further investigate whether B[a]P treatment had any effect on plaque initiation. At 12 weeks, TA and AA showed no or few plaques and were not further used for analysis. At 24 weeks a total of 42 initial lesions in the TA of the $\mathrm{B}[\mathrm{a}] \mathrm{P}$ group and 35 initial lesions in the controls were analyzed. In the AA a total of 42 and 35 initial lesions were analyzed respectively. Both TA and AA showed no significant differences between $\mathrm{B}[\mathrm{a}] \mathrm{P}$ and control animals in the mean number of initial lesions $(4.2 \pm 0.8$ versus $4.8 \pm 0.6$ and $4.2 \pm 0.8$ versus $5.8 \pm 0.7$, respectively) or the mean initial lesion size $(59,784 \pm 16,711$ versus $124,895 \pm$ 49,996 and $122,368 \pm 35,687$ versws $152,676 \pm 48,039 \mu^{2}$, respectively), indicating no effects of $\mathrm{B}[\mathrm{a}] \mathrm{P}$ treatment on initiation of lesions.

\section{P53, proliferation and apoptosis}

Since B[a]P is a carcinogen capable of inducing and promoting tumor formation, we were interested in its effect on the p53 protein, a very important cell cycle regulatory protein. Very low staining of p53 nuclear protein was observed in the normal vessel wall $(<2 \%)$. In the plaques however percentages of cells positive for the p53 nuclear protein staining were high $(69.9 \pm 3.1 \%)$, but these levels were not further induced by the 24 weeks of B[a]P treatment $(68.2 \pm 3.2 \%)$.

Moreover, B[a]P exposure did not result in enhanced proliferation as measured by the number of PCNA positive cells in both initial and advanced plaques after 24 weeks $(1.9 \pm 0.8 \%$ versus $3.9 \pm 2.0 \%$ and $4.0 \pm 0.7 \%$ versus $2.7 \pm$ $0.6 \%$ ).

Finally, the number of terminal dUTP nick-end labeling positive cells in plaques of the B[a]P-exposed animals was not significantly raised after 24 weeks $(1.25 \pm 0.17 \%$ versus $0.74 \pm 0.12 \% ; P=0.13)$.

\section{Plaque phenotype}

To investigate the effects of $\mathrm{B}[\mathrm{a}] \mathrm{P}$ exposure on plaque formation, we studied atherosclerotic plaques composition in more depth. After 24 weeks of exposure, advanced lesions in $\mathrm{B}[\mathrm{a}] \mathrm{P}$-treated animals exhibited more often plaque layering than advanced lesions of the control group (Figure $4.2 \mathrm{E}$ and F; 30 out of 36 lesions versus 13 out of 30 lesions, respectively). 

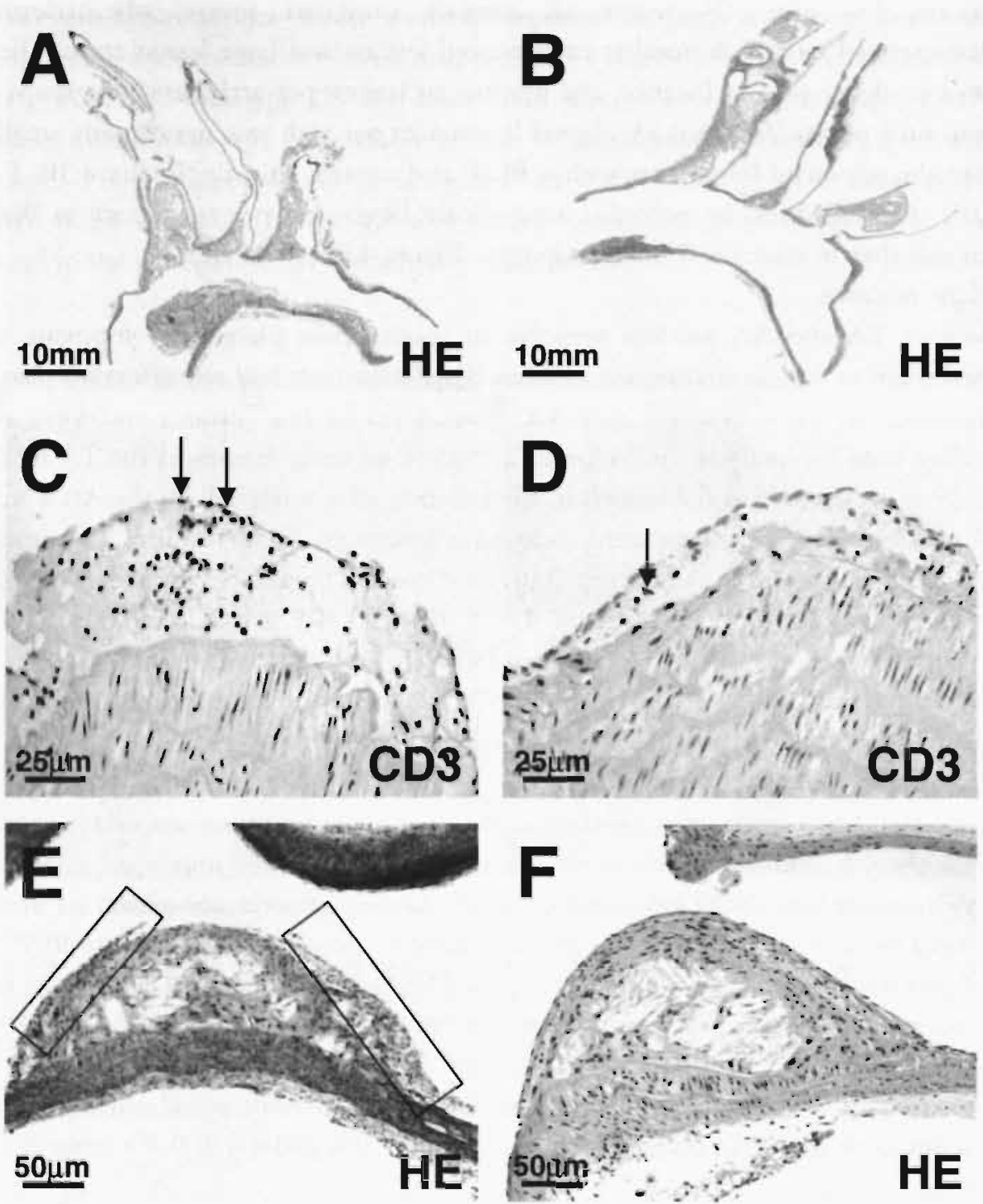

Figure 4.2 Representative longitudinal sections of the atric arch of a B[a]P (A) and a control apoE-KO mouse (B) after 24 weeks of exposure. Arherosclerotic plaques of the B[a]P animals contained more CD3 positive cells than plaques of the controls (C vs. D). As highlighted by the boxes, advanced plaques of the B[a]P-exposed mice were more often marked by the presence of plaque layers (E) than advanced plaques of the control mice (F). See also picture on back rumbover.

The cell density of these layers, which consisted mainly of macrophages, was significantly higher in the B[a]P-exposed animals $(P<0.05$; Figure $4.3 C$ ). Furthermore, in the $\mathrm{B}[\mathrm{a}] \mathrm{P}$ exposed group advanced lesions were more prone to 
lipid core development $(P<0.05$; Figure 4.3D). Both lipid core area and layering area did not differ between $\mathrm{B}[\mathrm{a}] \mathrm{P}$ and control animals (lipid core, $20.0 \%$ versus $21.3 \%$; layers, $19.3 \%$ versus $21.9 \%$, respectively). Total cell density of initial and advanced lesions was not influenced by B[a]P exposure at 12 and 24 weeks (data not shown).
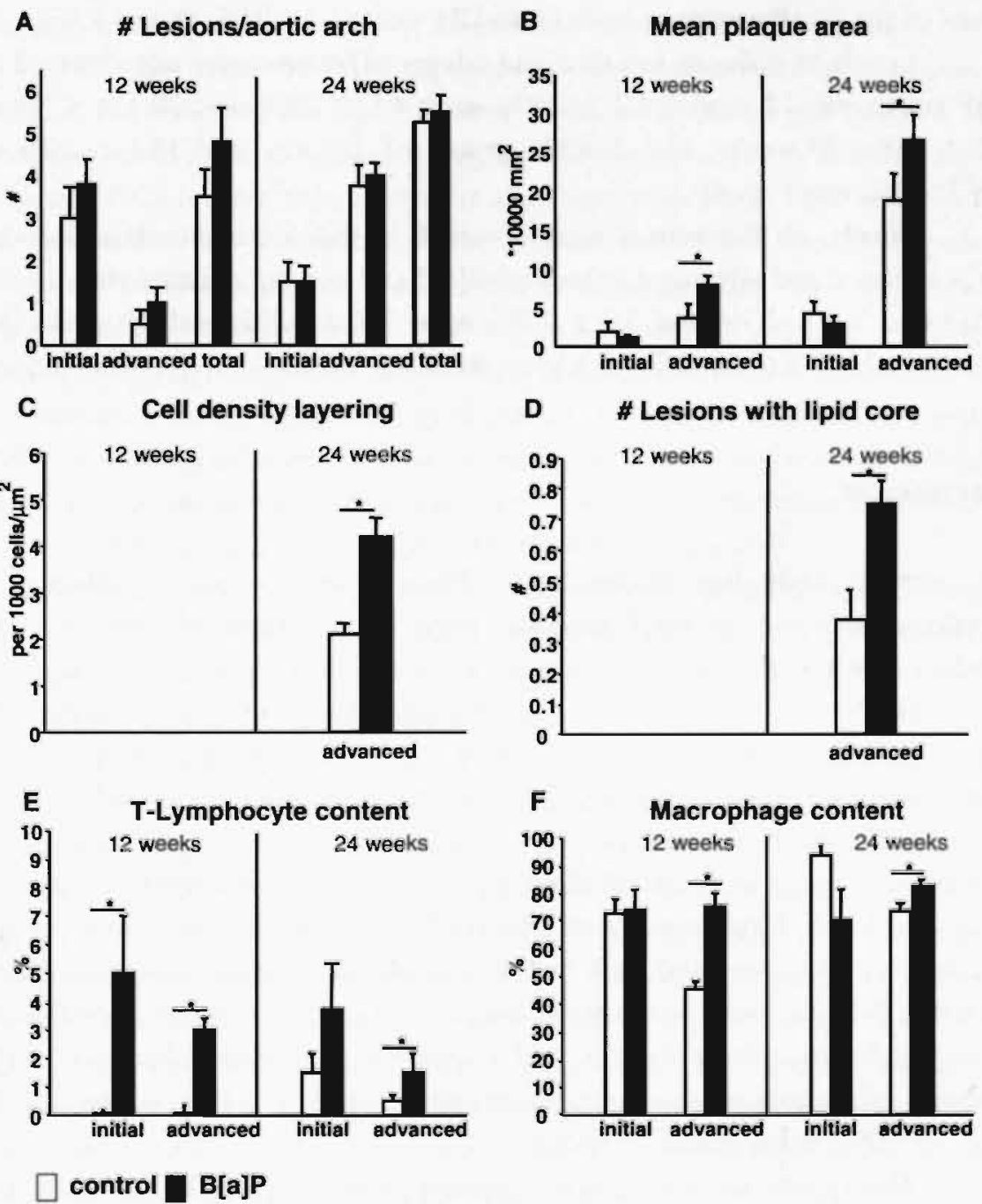

Figure 4.3. Plaque characteristics of the apoE-KO mice after 12 and 24 weeks of $B[a] P$ exposure. A: number of lesions per aortic arch; $\mathbf{B}$ : mean plaque area; $\mathbf{C}$ : cell density of the plaque layers; D: number of lesions with a lipid core; $\mathbf{E}$ : T-lymphocyte content; $\mathbf{F}$ : macrophage content. ${ }^{*} P<$ 0.05 . 
T-lymphocyte content, measured as the number of CD3-positive cells, was higher in lesions of the $\mathrm{B}[\mathrm{a}] \mathrm{P}$-treated animals at both time points compared to the control animals (Figure 4.2 C and D). Analysis of lesions in TA and AA showed no difference in T-lymphocyte content between plaques of exposed and control animals $(3.0 \pm 0.8 \%$ versus $2.1 \pm 0.5 \%$ and $1.9 \pm 0.5 \%$ versus $1.7 \pm 0.5 \%$; Figure 4.3E). Initial atherosclerotic lesions showed no differences in macrophage content, but a significant increase in macrophages was seen in advanced atherosclerotic lesions of the $\mathrm{B}[\mathrm{a}] \mathrm{P}$ groups at both 12 and 24 weeks $(P<0.05$; Figure $4.3 \mathrm{~F})$.

Levels of collagen in initial and advanced lesions were not changed upon B[a]P treatment ( 12 weeks, $4.2 \pm 2.8 \%$ versus $4.1 \pm 2.1 \%$ and $29.4 \pm 4.7 \%$ versus $34.5 \pm 1.0 \% ; 24$ weeks, $13.3 \pm 4.8 \%$ versus $16.3 \pm 9.4 \%$ and $38.1 \pm 2.2 \%$ versus $37.5 \pm 2.3 \%$, respectively).

Finally, no differences were observed in $\alpha$-smooth muscle actin-positive SMCs in initial and advanced lesions of B[a]P and control animals after $12(2.1 \pm$ $1.7 \%$ versus $2.3 \pm 2.3 \%$ and $7.7 \pm 2.2 \%$ versus $8.8 \pm 0.1 \%$ ) and 24 weeks $(8.2 \pm$ $3.9 \%$ versus $2.8 \pm 1.6 \%$ and $7.4 \pm 1.5 \%$ versus $6.0 \pm 1.0 \%$ ).

\section{Discussion}

The present study has focused on atherosclerotic plaque morphology and phenotype after chronic $\mathrm{B}[\mathrm{a}] \mathrm{P}$ exposure using genetic identically apoE- $\mathrm{KO}$ mice. First, we confirmed that $\mathrm{B}[\mathrm{a}] \mathrm{P}$ causes very high levels of DNA damage in the vessel wall. Because these levels were even higher than in lung, which is the normal target organ, this indicates that the vessel wall is extra vulnerable for this chemical. Furthermore, we showed that the observed effects of $\mathrm{B}[\mathrm{a}] \mathrm{P}$ on the atherosclerotic plaques could not be because of the induction of plasma lipids, because there was no consistent effect of $\mathrm{B}[\mathrm{a}] \mathrm{P}$ on these levels. In $\mathrm{B}[\mathrm{a}] \mathrm{P}$-treated apoE-/- mice larger advanced plaque development was observed. These plaques were more prone to lipid core development and high cell-densed plaque layering. Interestingly, B[a]P treatment did not result in the induction of $p 53$ nuclear protein or proliferation, but in a higher plaque macrophage and $\mathrm{T}$-lymphocyte content, whereas no signs of systemic inflammation were present in spleen or liver. This suggests a local, plaque-specific, inflammatory response.

The effects of chemicals on atherogenesis were studied as early as the 1970s when Albert and colleagues ${ }^{20}$ demonstrated that chronic exposure to the PAH 7,12-dimethylbenz(a)anthracene (DMBA) resulted in large, focal, fibromuscular lesions in the abdominal aorta of chickens. They showed not only an increased induction, but also larger lesions in the carcinogen-treated animals as 
compared to the controls. Although later studies confirmed the dose-dependent increase of the plaque size, no further studies have described the induction of new plaques. ${ }^{21,22,23}$ Our data also show an increase in lesion size but not in number of lesions. Another observation from our study was that carcinogen exposure did not alter the location of the lesions, which is in line with observations from others. ${ }^{21,23}$ The fact that $\mathrm{B}[\mathrm{a}] \mathrm{P}$ increased lesion size, but had no influence on the number and the location of the lesions, leads to the suggestion that this environmental carcinogen accelerates the process of atherosclerosis, rather than initiating it.

The main route of PAH exposure is via dietary intake of contaminated foodstuffs. For example, the B[a]P content of charcoal-broiled and smoked foods has been reported to be as high as $50 \mu \mathrm{g} / \mathrm{kg}$. Furthermore, PAHs are detected in a wide range of fresh meat, fish, vegetables and fruits; high levels were found in leafy green vegetables as a result of the deposition from the PAH-polluted atmosphere. ${ }^{24} \mathrm{~A}$ Dutch total diet study calculated that the daily PAH intake ranged up to $1.4 \mu \mathrm{g} / \mathrm{kg} .{ }^{25}$ Specific groups that are more frequently exposed to PAH via inhalation are cigarette smokers and workers in industries such as asphalting, steeland aluminum industry. Epidemiological studies showed that smokers and workers in PAH-producing industries are at increased risk for cardiovascular disease. ${ }^{26}$ Actually, several cross-sectional studies have shown a relationship between both active and passive smoking and carotid artery atherosclerosis. ${ }^{27,28}$

It is suggested that $\mathrm{B}[\mathrm{a}] \mathrm{P}$ is transported through the blood via lipoproteins and may therefore preferentially be delivered to the arterial wall. ${ }^{29}$ Metabolites of carcinogens such as B[a]P are able to covalently bind to the DNA. These BPDEDNA adducts can lead to the formation of mutations that can subsequently result in uncontrolled cell growth and possibly cancer. ${ }^{3}$ In humans, BPDE-DNA adducts have been detected in aorta by both ${ }^{32} \mathrm{P}$-postlabeling as well as by specific fluorimetric assays. ${ }^{10}$ Moreover, several animal studies have shown that independently of the exposure route, PAHs lead to very high adduct levels in lung and heart but also in aorta. ${ }^{930}$ In our study, B[a]P exposure resulted in DNA damage, which was most pronounced in the aorta. After 24 weeks of exposure, DNA-adduct levels in aorta, lung and liver showed no increase compared to 12 weeks of exposure, which suggests that adduct levels had reached steady state levels. Since the DNA adducts were similarly distributed in wild-type C57B/6 mouse acutely exposed to $\mathrm{B}[\mathrm{a}] \mathrm{P}$, and the chronically exposed atherosclerotic apoEKO mouse, B[a]P-induced DNA damage proved not to be specific for the atheroscleroric vessel nor the result of metabolic changes associated with the diseased vessel wall. It can therefore be concluded that arterial DNA damage precedes plaque formation. The lung, which is considered to be a target organ for $\mathrm{B}[\mathrm{a}] \mathrm{P}$-induced carcinogenicity, showed adduct levels $50 \%$ lower than those in the 
aorta. Comparable results were seen in smokers, having highest DNA damage in organs like heart and aorta. ${ }^{4}$

Although the pathophysiological mechanism of chemical atherogenesis is unkown, several theories have been postulated. One of the theories is the monoclonal hypothesis. ${ }^{6}$ Benditt and Benditt ${ }^{6}$ suggested that a somatic mutational event in a single smooth muscle cell gives a proliferative advantage that initiates the atherosclerotic process. Studies from Bond and colleagues ${ }^{21}$ showed that proliferation rates of medial and lesion cells were mainly due to increasing body weight due to maturing, whereas varying duration of exposure to the carcinogenic PAH DMBA in cockerels had no effect. On the other hand, Batastini and Penn ${ }^{23}$ described that DMBA enhanced proliferation of plaque cells, beyond levels normally seen in plaques. This enhanced proliferation was seen in pre-existing lesions, suggesting that chemical carcinogens act as promotors of plaque development rather than as initiators. In parallel, in our study proliferation levels in the atherosclerotic plaque were not raised on $\mathrm{B}[\mathrm{a}] \mathrm{P}$ exposure, thereby suggesting that the monoclonal theory does not explain the mechanism of chemical atherogenesis. Furthermore, we did not observe any differences in the levels of p53 nuclear protein in plaques of B[a]P-exposed and control animals. Data from a human study also suggested that p53 was not involved in atherogenesis. ${ }^{31}$ However, in this study p53 nuclear staining was not measured in the atherosclerotic plaque but in the medium layer underlying the plaque. Elevated levels of p53 lead to anti-proliferative and pro-apoptotic responses. ${ }^{32}$ Although it is suggested that the absence of $\mathrm{p} 53$ accelerates atherosclerosis by causing increased proliferation, the effect of $\mathrm{p} 53$ on apoptosis in the atherosclerotic plaque is less cleat. For instance, van Vlimen and colleagues ${ }^{32}$ showed that p53 deficiency resulted in a slight decrease in apoptosis, whereas Guevara and colleagues ${ }^{33}$ reported a non-significant increase suggesting that apoptosis could be p53independent. In our study levels of apoptosis were slightly higher in B[a]P-exposed animals without differences in levels of $\mathrm{p} 53$. Although $\mathrm{B}[\mathrm{a}] \mathrm{P}$ is known to induce p53, one might speculate that the already elevated p53 levels in the atherosclerotic lesions might have masked a stimulatory effect of $\mathrm{B}[\mathrm{a}] \mathrm{P}$.

The current view on atherosclerosis postulates that atherosclerosis is a chronic inflammatory process. ${ }^{3+}$ It states that the process of atherosclerosis begins as an inflammatory response in the arterial wall as a response to the accumulation of toxic products. ${ }^{35}$ Interestingly, B[a]P is not only known because of its mutagenic and carcinogenic capacity, but also because of its immunomodulating effects. ${ }^{36}$ For example, B[a]P is capable of oxidizing low-density lipoprotein, which has proven to be a trigger for an inflammatory response. ${ }^{37,38}$ Furthermore, in rodents it is shown that B[a]P suppresses T-cell-dependent antibody formation. ${ }^{39}$ 
In vitro studies have suggested that BPDE might be the ultimate immunotoxic $\mathrm{B}$ [a]P metabolite, since inhibition of the aryl hydrocarbon (Ah)-receptor, necessary for the metabolism of B[a]P to BPDE, inhibited this suppression. ${ }^{36}$ In our study, we proved BPDE levels to be high in the arterial wall which is accompanied by increased T-lymphocyte levels in both initial and advanced plaques of B[a]Pexposed mice. Furthermore, advanced lesions of the B[a]P animals contained a higher macrophage content and were more prone to develop lipid cores. Although detailed studies are necessary to further dissect the molecular pathway of immunomodulation by $\mathrm{B}[\mathrm{a}] \mathrm{P}$ on plaque formation, it seems that an inflammatory response plays an important role in chemical atherogenesis.

In conclusion, in the present study we showed that $\mathrm{B}[\mathrm{a}] \mathrm{P}$ was a potent promotor of the atherosclerotic process, while no signs of initiation of new plaques could be observed. Although substantial aortic DNA damage was caused by $\mathrm{B}[\mathrm{a}] \mathrm{P}$, this was not accompanied by increased levels of proliferation or $\mathrm{p} 53$ accumulation in the plaques. Importantly however, our data demonstrated B[a]Prelated changes in plaque phenotype illustrared by an increased plaque layering and number of lipid cores, but mostly by the increased levels of inflammatory cells in the arherosclerotic plaques after $\mathrm{B}[\mathrm{a}] \mathrm{P}$ exposure. This suggests that $\mathrm{B}[\mathrm{a}] \mathrm{P}$-related progression of atherosclerosis involves a local inflammatory response. 


\section{References}

1. Ross JS, Stagliano NE, Donovan MJ, Breitbart RE, Ginsburg GS: Atherosclerosis and cancer: common molecular pathways of disease development and progression. Ann N Y Acad Sci 2001, 947:271-292; discussion 292-273

2. Waldman JM, Lioy PJ, Greenberg A, Butler JP: Analysis of human exposure to benzo(a)pyrene via inhalation and food ingestion in the Total Human Environmental Exposure Study (THEFS). J Expo Anal Environ Epidemiol 1991, 1:193-225

3. Polynuclear aromatic compounds, Part 1, Chemical, environmental and experimental data. IARC Monogr Eval Carcinog Risk Chem Hum 1983, 32:1-453

4. De Flora S, Izzotti A, Randerath K, Randerath E, Bartsch H, Nair J, Balansky R, van Schooten F, Degan P, Fronza G, Walsh D, Lewtas J: DNA adducts and chronic degenerative disease. Pathogeneric relevance and implications in preventive medicine. Mutat Res 1996, 366:197-238

5. Wakabayashi K: International Commission for Protection Against Fnvironmental Mutagens and Carcinogens. ICPEMC Working Paper 7/1/3. Animal studies suggesting involvement of mutagen/carcinogen exposure in atherosclerosis. Mutat Res 1990, 239:181-187

6. Benditt EP, Bendit JM: Evidence for a monoclonal origin of human atherosclerotic plaques. Proc Narl Acad Sci U S A 1973, 70:1753-1756

7. Penn A, Snyder C: Arteriosclerotic plaque development is 'promoted' by polynuclear aromaric hydrocarbons. Carcinogenesis 1988, 9:2185-2189

8. Penn A, Garte SJ, Warren L, Nesta D, Mindich B: Transforming gene in human atherosclerotic plaque DNA. Proc Narl Acad Sci U S A 1986, 83:7951-7955

9. Izzotti A, Camoirano A, Cariglia C, Tampa E, De Flora S: Formation of DNA adducts in the aorta of smoke-exposed rats, and modulation by chemopreventive agents. Mutat Res 2001, 494:97-106

10. Izzori A, De Flora S, Perrilli GL, Gallagher J, Rojas M, Alexandrov K, Bartsch H, Lewtas J: Cancer biomarkers in human atherosclerotic lesions: detection of DNA adducts. Cancer Epidemiol Biomarkers Prev 1995, 4:105-110

11. Binkova B, Strejc P, Boubelik O, Stavkova Z, Chvatalova I, Sram RJ: DNA adducts and human atherosclerotic lesions. Int J Hyg Environ Health 2001, 204:49-54

12. De Flora S, Izzoti A, Walsh D, Degan P, Petrilli GL, Lewtas J: Molecular epidemiology of atherosclerosis. Faseb J 1997, 11:1021-1031

13. Van Schooten FJ, Hirvonen A, Maas LM, De Mol BA, Kleinjans JC, Bell DA, Durrer JD: Putative susceptibility markers of coronary artery disease: association between VDR genotype, smoking, and aromatic DNA adduet levels in human tight atral tisste. Fascb ] 1998, 12:14091417

14. Marinet W, Knapen MW, De Meyer GR, Hermañ AG. Kockx MM: Elevared levels of oxidarive DNA damse and DNA repair enzymes in human atheroselerotic phaques. Circulation 2002, 106:927-932

15. Nakashima Y, Plump AS, Raines EW. Breslow JL, Ross R: ApoE-deficient mice develop lesions of all phases of atherosclerosis throughout the arterial tree. Arterioscler Thromb 1994, 14:133140

16. Fazio \$, Linton MF: Mouse models of hyperlipidemia and atherosclerosis. Froni Biosci 2001. 6:D 515.525

17. Godschalk RW, Maas LM, Van Zandwijk N, ran'r Veer LJ. Breedijk A, Borm PJ, Verhaert J. Kleinins $j \mathcal{C}$, van Schooten FJ: Differences in aromatic-DNA adduct levels between alveolar macrophages and subpopulations of whic blood cells from snokers. Carcinogenesis 1008. $19.810-825$

18. Stary H, Btankenhom D, Chandler A, Glagov S, Insull W. Richandson M, Rosenfeld M, Schaffer S, Schwarz $C$, Wagnet W. Wissler R: A detinition of advaneed types of atherosclerotic lesions and a hiswogical classification of arherosclerosis. Arteriosclerosis, thrombosis and vascular biology $1995,15: 1513-1531$

19. Lutgens E, de Muinck ED. Hecneman S, Dacmen MI: Compensatory enlargement and stenosis. develop in apoE $(-/-)$ and apoE*3-Leiden ransgenic mice. Arterioscler Thromb Vase Biol 2001, $21: 1359-1365$ 
20. Albert RE, Vanderlaan M, Burns FJ, Nishizumi M: Effect of carcinogens on chicken atherosclerosis. Cancer Res 1977, 37:2232-2235

21. Bond JA, Gown AM, Yang HL, Benditt EP, Juchau MR: Further investigations of the capacity of polynuclear aromatic hydrocarbons to elicit atherosclerotic lesions. J Toxicol Environ Health $1981,7: 327-335$

22. Penn A, Batastini G, Soloman J, Burns F, Albert R: Dose-dependent size increases of aortic lesions following chronic exposure to 7,12-dimethylbenz(a)anthracene. Cancer Res 1981, 41:588592

23. Batastini G, Penn A: An ultrastructural comparison of carcinogen-associated and spontaneous aortic lesions in the cockerel. Am J Pathol 1984, 114:403-409

24. Grimmer G, Stober W, Jacob J, Mohr U, Schoene K, Brune H, Misfeld J: Inventory and biological impact of polycyclic carcinogens in the environment. Exp Pathol 1983, 24:3-13

25. de Vos $\mathrm{RH}$, van Dokkum W, Schouten A, de Jong-Berkhout P: Polycyclic aromatic hydrocarbons in Dutch total diet samples (1984-1986). Food Chem Toxicol 1990, 28:263-268

26. Howard G, Wagenknecht LE, Burke GL, Diez-Roux A, Evans GW, MeGovern P, Nieto FJ, Tell GS: Cigarette smoking and progression of atherosclerosis: The Atherosclerosis Risk in Communities (ARIC) Study [see comments]. Jama 1998, 279:119-124

27. Tell GS, Polak JF, Ward BJ, Kitmer SJ, Savage PJ, Robbins J: Relation of smoking with carotid artery wall thickness and stenosis in older adults. The Cardiovascular Health Study. The Cardiovascular Health Study (CHS) Collaborative Research Group. Circulation 1994, 90:29052908

28. Howard G, Burke GL, Szklo M, Tell GS, Eckfeldt J, Evans G, Heiss G: Active and passive smoking are associated with increased carotid wall thickness. The Atherosclerosis Risk in Communities Study. Arch Intern Med 1994, 154:1277-1282

29. Stavenow L, Pessah-Rasmussen H: Effects of polycyclic aromatic hydrocarbons on proliferation, collagen secretion and viability of arterial smooth muscle cells in culture. Artery 1988, 15:94-108

30. Godschalk RW, Vermeer IT, Kriek E, Floot B, Schilderman PA, Moonen EJ, Kleinjans JC, van Schooten FJ: Comparison of 32P-postlabeling and HPLC-FD analysis of DNA adducts in rats acutely exposed to benzo(a)pyrene. Chem Biol Interact 1997, 104:41-54

31. D'Agostini F, Fronza G, Campomenosi P, Izzotti A, Petrilli GL, Abbondandolo A, De Flora S: Cancer biomarkers in human atherosclerotic lesions: no evidence of p53 involvement. Cancer Epidemiol Biomarkers Prev 1995, 4:111-115

32. van Vlijmen BJ. Gerritsen G, Franken AL, Boesten LS, Kockx MM, Gijbels MJ, Vierboom MP, van Eck M, van De Water B, van Berkel TJ, Havekes LM: Macrophage p53 deficiency leads to enhanced atherosclerosis in APOE*3-Leiden transgenic mice. Circ Res 2001, 88:780-786

33. Guevara NV, Kim HS, Antonova EI, Chan L: The absence of p53 accelerates atherosclerosis by increasing cell proliferation in vivo. Nat Med 1999, 5:335-339

34. Hansson GK: immune mechanisms in atherosclerosis. Arterioseler Thromb Vasc Biol 2001, 21:1876-1890

35. Ross R: Atherosclerosis-an inflammatory disease. N Engl J Med 1999, 340:115-126

36. White KI, Jr., Holsapple MP: Direct suppression of in vitro antibody production by mouse spleen cells by the carcinogen benzo(a)pyrene but not by the noncarcinogenic congener benzo(e)pyrene. Cancer Res 1984, 44:3388-3393

37. Berliner JA, Navab M, Fogelman AM, Frank JS, Demer LI, Edwards PA, Watson AD, Lusis Af: Atherosclerosis: basic mechanisms. Oxidation, inflammation, and genetics. Circulation 1995, 91:2488-2496

38. Zhou X, Stemme S, Hansson GK: Evidence for a local immune response in atherosclerosis. CD4 $+\mathrm{T}$ cells infiltrate lesions of apolipoprotein-E-deficient mice. Am J Pathol 1996, 149:359366

39. De Jong WH, Kroese ED, Vos JG, Van Loveren H: Detection of immunotoxicity of benzo[alpyrene in a subacute toxicity study after oral exposure in rats. Toxicol Sci 1999, 50:214 220 



\section{Chapter 5}

\section{Polycyclic aromatic hydrocarbons induce an inflammatory plaque phenotype irrespective of their DNA binding properties}

Daniëlle M.J. Curfs, Daniëlle M.F.A. Pachen, Ad M. Knaapen, Marion J.J. Gijbels, Marjan L.F. Smook, Mark M. Kockx, Mat J.A.P. Daemen, Frederik J. van Schooten 


\section{Abstract}

To obtain more insight in the mechanism by which polycyclic aromatic hydrocarbons (PAHs) influence atherosclerotic plaque formation in apolipoprotein E knockout (apoE-KO) mice, we performed a study in which the effects of chronic exposure to the DNA adduct forming PAH benzo[a]pyrene $(B[a] P)$ were compared to those of its non-adduct forming structural isomer benzo[e]pyrene $(\mathrm{B}[\mathrm{e}] \mathrm{P})$. Fifty apoE-KO mice were randomly divided among three exposure groups: B[a]P, B[e]P and the vebiculum control tricapryline. Starting at 5 weeks of age, all animals received a weekly oral dose of $5 \mathrm{mg} / \mathrm{kg}$ bw B[a]P, B[e]P or tricapryline for 24 weeks. At the end of the trial, peripheral blood T- and Blymphocytes, granulocytes and macrophages were assessed by flow cytometry. Lung tissue was used for the assessment of DNA adducts, and the aortic arch and thoracic aorta for the quantification and phenotyping of atherosclerotic lesions. No differences in blood immunological cells were observed between the PAH-exposed animals and the controls. Number and location of plaques per arch did not differ between the three exposure groups. There was no significant difference in the total plaque burden per arch between the B[a]P and $\mathrm{B}[\mathrm{e}] \mathrm{P}$ groups or the controls $\left(153,087 \pm 9,855,209,793 \pm 34,940\right.$, and $130,571 \pm 13,923 \mu^{2}$ respectively). However, both $\mathrm{B}[\mathrm{a}] \mathrm{P}$ - and $\mathrm{B}[\mathrm{e}] \mathrm{P}$-exposed mice exhibited a more inflammatory plaque phenotype, characterized by an increase in CD 45 and CD 3 positive cells, compared to the controls (CD45: $15 \pm 1.6 \times 10^{-5}, 15 \pm 2.2 \times 10^{-5}, 8.8 \pm 2.0 \times 10^{-5}$, $P<0.05$; CD3: $6.1 \pm 1.4 \times 10^{-5}, 4.5 \pm 0.59 \times 10^{-5}, 2.1 \pm 0.53 \times 10^{-5}, P<0.05 \mathrm{~B}[\mathrm{a}] \mathrm{P}$, $\mathrm{B}[\mathrm{e}] \mathrm{P}$ and control respectively). Additionally, more $\mathrm{B}[\mathrm{a}] \mathrm{P}$ and $\mathrm{B}[\mathrm{e}] \mathrm{P}$ treated animals exhibited high TGF $\beta 1$ protein expression in the plaques compared to the controls (62.5, 40.0 and $22.2 \%$ of the animals respectively) In conclusion, although Bje]P does not form bulky DNA adducts, this study shows that it elicits an inflammatory atherosclerotic plaque phenotype that is comparabie to the phenotype induced by the DNA adduct forming B[a]P. These results suggest that bulky DNA adduct formation is not involved in the stimulatory effects of PAHs on plaque phenotype in apoE-KO mice. Furthermore, our data indicare a possible role of TGF $\beta 1$ in the PAH-induced inflammatory plaque phenotype. 


\section{Introduction}

As the most important clinical manifestation of cardiovascular diseases (CVDs), atherosclerosis has been the subject of extensive study during the last several decades. This disease of the large arteries starts early in childhood, but does often not show its first symptoms until middle life. ${ }^{1,2}$ Several hypotheses regarding the ontogenesis of atherosclerosis have been postulated and the most common idea is that atherosclerosis is an inflammatory response to injury of the large blood vessels. ${ }^{3}$ One of the causes of this injury could be a toxic insult to the vessel wall. ${ }^{4}$ It has been suggested that due to this injury, an arterial smooth muscle cell mutates and transforms into a proliferative clone, similar to the most widely held theory of carcinogenesis. ${ }^{5}$ Among the risk factors for atherosclerosis is the exposure to environmental carcinogens like polycyclic aromatic hydrocarbons (PAHs).$^{6-9} \mathrm{PAHs}$ are biologically inert, but upon entering the organism they can be metabolised into reactive intermediates that can bind covalently to the DNA. These so called PAHDNA adducts are considered to play a crucial role in PAH-mediated carcinogenesis. ${ }^{10}$ Since PAH exposure did not only lead to high levels of DNA adducts in lung but also in aorta, a mutual role for the PAH-DNA adducts in the development of both cancer and atherosclerosis has been suggested. However, although animal and human studies have indeed demonstrated the association between PAH-DNA adduct formation and atherogenesis, ${ }^{911}$ the underlying mechanisms remain speculative. In previous studies, we have shown that benzo[a]pyrene $(\mathrm{B}[\mathrm{a}] \mathrm{P})$, a known carcinogenic $\mathrm{PAH}$, was indeed capable of inducing high levels of DNA damage in the aorta of apolipoprotein $\mathrm{E}$ knockout (apoE-KO) mice (chapters 2 and 4).12,13 This was accompanied by an enhanced progression of arherosclerosis, most likely due to a local inflammatory response (chapter 4). ${ }^{13}$ It is however still unknown whether this inflammatory stimulus of benzo[a]pyrene is related to its DNA adduct forming potency. The aim of the present study was to further dissect the specific role of DNA adduct formation in PAH-mediated atherogenesis. Therefore, atherogenic apoE-KO mice were exposed to either $\mathrm{B}[\mathrm{a}] \mathrm{P}$ or its non-adduct forming counterpart benzo[e]pyrene $(\mathrm{B}[\mathrm{e}] \mathrm{P})$.

In contrast to $\mathrm{B}[\mathrm{a}] \mathrm{P}, \mathrm{B}[\mathrm{e}] \mathrm{P}$ has proven to be very weak or noncarcinogenic, most likely because it does not interact with the Ah receptor, ${ }^{14,15}$ which is a necessary step to activate the drug metabolizing enzyme system cytochrome P450. Furthermore, even in the presence of metabolizing enzymes, the symmetric structure of $\mathrm{B}[\mathrm{e}] \mathrm{P}$ causes steric hinderence, making it very difficult to form reactive metabolites. As a result no or only very low levels of reactive intermediates and thus DNA adducts are formed. ${ }^{16-18} \mathrm{As}$ such, the use of B[e]P can 
be considered as a highly specific tool to further elucidare the role of DNA adduct formarion in $\mathrm{B}[\mathrm{a}] \mathrm{P}$-induced and inflammation mediated atherogenesis. ${ }^{13}$

\section{Materials and Methods}

\section{Animal treatment}

50 male apoE-KO mice (purchased from IFFA CREDO S.A. a Charles River Company, Lyon, France), 5 weeks of age $(18.9 \pm 0.3 \mathrm{~g})$, were randomly divided into three exposure groups: $\mathrm{B}[\mathrm{a}] \mathrm{P}(n=20), \mathrm{B}[\mathrm{e}] \mathrm{P}(n=20)$ and the control group $(n$ $=10$ ). Once per week, all animals were exposed to $5 \mathrm{mg} / \mathrm{kg}$ bw B $[\mathrm{a}] \mathrm{P}, \mathrm{B}[\mathrm{e}] \mathrm{P}$ or tricaprylin by gavage. This procedure was repeated for 24 consecutive weeks. Mice were housed under standard conditions at the animal facility of the University of Maastricht. Water and normal chow were provided ad libitum.

B[a]P and B[e]P (B1760 and B8382, Sigma, St. Louis, MO, USA) were dissolved in acetone and mixed with the tricaprylin (103104, ICN, Irvine, CA, USA). A homogenous solution of $0.5 \mathrm{mg} \mathrm{B}[\mathrm{a}] \mathrm{P}$ or B[e]P / ml tricaprylin was produced by evaporation of the acetone for 5 hours under nitrogen. Whereas $\mathrm{B}[\mathrm{a}] \mathrm{P}$ is a potent carcinogen, benzo[e]pyrene $(\mathrm{B}[\mathrm{e}] \mathrm{P})$, the structurally related counterpart of $\mathrm{B}[\mathrm{a}] \mathrm{P}$, is almost completely inactive. Both PAHs contain 5 benzene rings and they differ only in the position at which the benzo-ring is annealed to pyrene (Figure 5.1).

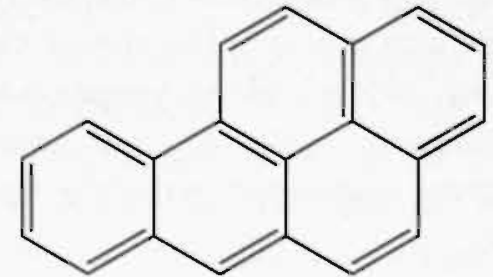

Benzo[a]pyrene

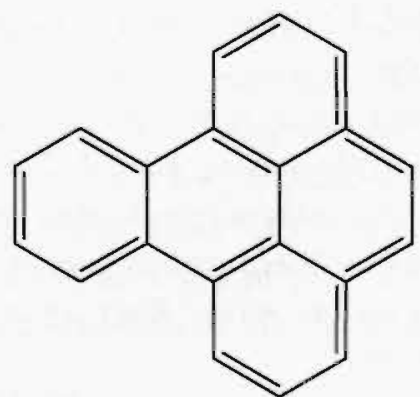

Benzo[e]pyrene

Figure 5.1 Chemical structure of benzo[a]pyrene and its isomer benzo[e]pyrene. 


\section{Flow cytometry}

One week before the end of the exposure protocol, $50 \mu \mathrm{l}$ of heparinized blood was collected from all animals by tail bleeding. Blood was processed immediately and the erythrocytes were removed by hypotonic lysis with $\mathrm{NH}_{4} \mathrm{Cl}$. For the detection of T and B-lymphocytes, cells were stained with CD3-FITC (17A2) or CD45RBPE (RA3-6B2) respectively. Granulocytes and macrophages were detected using Ly-6G and Ly-6C FITC-labeled (RB6-8C5) and CD11b/Mac-1 PE-labeled (M1/70) respectively. All antibodies were supplied by BD-Pharmingen (San Diego, CA, USA). Flow cytometry was performed on a FACS Calibur and the results were analyzed using CellQuest software (BD-Science, San Diego, CA, USA). Calculations of $\mathrm{T}$ - and B-cells were based on $2 \times 10^{4}$ viable positively stained cells. Percentages of granulocytes and macrophages were calculated based on $5 \times 10^{3}$ viable positively stained cells.

\section{Tissue processing}

Upon euthanasia, animals were anesthetized by i.p. injection of $0.5 \mathrm{ml} / \mathrm{kg}$ Nembutal ${ }^{*}$. Tissue processing was performed as described previously. ${ }^{13}$ In short, the arterial tree was perfused in situ with $0.9 \% \mathrm{NaCl} / 20 \%$ nitroprusside (3 minutes) and $1 \%$ phosphate-buffered paraformaldehyde (3 minutes) through a catheter in the apex of the heart. Subsequently, the complete arterial tree was excised, fixed overnight in $1 \%$ phosphate-buffered paraformaldehyde, and embedded in paraffin. Lung and liver were taken out and used for histological examination. Lung was further used for DNA isolation and subsequent DNA adduct measurement.

\section{Lipid profile}

Plasma cholesterol levels were determined by using standard enzymatic kits (Sigma and Hoffman-La Roche), the colorimetric analyses was automated on the Cobas Fara centrifugal anaiyzer (Hoffmann-La Roche, LTD, Basel, Switzerland). Standardized serum (Precipath) was used as an internal standard. LDL was calculated using the formula: LDL cholesterol $(\mathrm{mmol} / \mathrm{L})=$ total cholesterol (triglycerides / 2.2) - HDL cholesterol.

\section{Morphometry and immunobistocbemistry}

Four hematoxylin and eosin stained sections (each $20 \mu \mathrm{m}$ apart) of the aortic arch as well as the thoracic aorta were used to measure plaque area using the Leica 570 Quantimet morphometry system.

Sections were immunolabeled for the detection of plaque total inflammatory cells (CD45, 1:50, Pharmingen), plaque T-lymphocytes (CD3, 1:80, 
Labvision, Montreal, Canada), TGF $\beta 1$ (TGF $\beta 1,1: 30$ R\&D Systems Inc, Minneapolis, MN, USA), macrophages (Mac-3, 1:30, BP-Pharmingen), and oxidative (8-OHdG) DNA damage (N45.1, 1:150, Japan Institute for the Control of Aging, Japan). Apoptotic cell death was detected by TUNEL staining (ApopTag kit, Oncor, Gaithersburg, MD, USA) performed in the lab of Dr. M. Kockx (Antwerp, Belgium). Total inflammatory cell content, T-cell content, 8-OHdG, and apoptotic cell content were quantified by counting the number of $\mathrm{CD} 45, \mathrm{CD} 3,8$ $\mathrm{OHdG}$, and TUNEL positively stained cells respectively, divided by the total plaque area. Macrophage content was measured by dividing the MAC3 positive cell area by the total plaque area. Finally, based on the TGF $\beta 1$ protein staining intensity of the plaque macrophages, animals were semi-qualitatively classified into low or high TGF $\beta 1$ protein expression.

\section{DNA isolation and bulky DNA adduct analysis}

DNA was isolated from lung by overnight lysis with SET/SDS containing 50 $\mu \mathrm{g} / \mathrm{ml}$ Proteinase $\mathrm{K}$ at $55^{\circ} \mathrm{C}$. DNA was isolated using a 3-step standard phenol extraction. ${ }^{19}$ The DNA was precipitated with $3 \mathrm{M}$ sodiumacetate and cold ethanol and dissolved in $2 \mathrm{mM}$ Tris ( $\mathrm{pH} 7.4$ ) until a final concentration of $2 \mathrm{mg} / \mathrm{ml}$.

The ${ }^{32} \mathrm{P}$-postlabeling assay was used to quantify bulky DNA adduct levels and performed as described earlier. ${ }^{19}$ In short, $10 \mu \mathrm{g}$ DNA was digested into deoxyribonucleoside 3'-monophosphates using micrococcal endonuclease $(0.25$ $\mathrm{U} / \mu \mathrm{l})$ and spleen phosphodiesterase $(2 \mu \mathrm{g} / \mu \mathrm{l})$ Subsequently, nuclease P1 (2.5 $\mu \mathrm{g} / \mu \mathrm{l})$ adduct enrichement was performed ( 40 minutes at $37^{\circ} \mathrm{C}$ ). Nucleotides were labeled with $\left[\gamma^{-32} \mathrm{P}\right]$-ATP $(50 \mu \mathrm{Ci} /$ sample $)$ in the presence of T4-polynucleotide kinase $(10 \mathrm{U} / \mu \mathrm{l})$. Radiolabeled adduct nucleotide biphosphates were separated by thin layer chromatography on polyerhyleneimine (PEI) cellulose sheets (Magerey Nagel, Düren, Germany). For quantification, 2 standards of [3H]BPDE modified DNA (1 adduct per $10^{7}$ and 1 adduct per $10^{8}$ nucleotides, respectively) were included in each experiment. Quantification towards the standards was performed by means of phosphor-imaging technology (Molecular Dynamics, Sunnyrale ${ }^{T M}$, CA, USA) with a detecrion limit of 1 adduct per $10^{\circ}$ nucleorides.

\section{Statistical analysis}

Results are presented as mean \pm SEM. Data were analyzed using the nonparametric Mann-Whitncy U test. A Chi-square test was performed to evaluate differences in plaque TGF $\beta 1$ protein expression. The level of staristical significance was set at $P<0.05$. All analyses were performed by two independent observers who were blinded for the expasure protocol. Both inter- and intra observer variation were less than $10 \%$. 


\section{Results}

\section{General}

During the trial 8 animals died, 3 out of 20 animals of the B[e]P group, 4 out of 20 animals of the B[a]P group and 1 out of 10 animals of the control group. At the end of the trial, the body weight of both $\mathrm{B}[\mathrm{e}] \mathrm{P}$ - and $\mathrm{B}[\mathrm{a}] \mathrm{P}$-exposed animals was lower than the body weight of the control animals $(P<0.05$, Table 5.1). Pathology of lung and liver showed no major abnormalities like tumor formation or excessive inflammation. No significant differences were found between the relative liver weights of the three exposure groups (Table 5.1). Plasma lipid levels at the end of the trial were not significantly modulated by the PAH exposure (Table 5.1).

Measurement of DNA adduct levels in lung tissue of the B[a]P, B $[\mathrm{e}] \mathrm{P}$ and control groups confirmed that in contrast with $\mathrm{B}[\mathrm{a}] \mathrm{P}, \mathrm{B}[\mathrm{e}] \mathrm{P}$ hardly formed any reactive diol epoxides which can bind to the DNA. The adducts detected in lung of the $\mathrm{B}[\mathrm{e}] \mathrm{P}$ and control animals were below the detection limit and did not exceed the background levels, while they were significantly elevated in B[a]P-exposed animals (Table 5.1).

Table 5.1 Growth, DNA adducts and lipoprotein levels.

\begin{tabular}{lccc}
\hline \multicolumn{1}{c}{ Growth } & Control & B [e]P & B[a]P \\
\hline Weight after $(\mathrm{g})$ & $(n=9)$ & $(n=17)$ & $(n=16)$ \\
Relative liver weight* & $32.1 \pm 0.7$ & $29.1 \pm 0.4$ & $30.0 \pm 0.3$ \\
$\quad 0.045 \pm 0.004$ & $0.042 \pm 0.004$ & $0.043 \pm 0.003$ \\
DNA adducts & & & \\
Lung (adducts per $10^{8}$ nucl) & $<0.1$ & $<0.1$ & $13.2 \pm 1.2^{* *}$ \\
$\quad$ Lipoprotein levels & $(n=6)$ & $(n=6)$ & $(n=6)$ \\
Tonal cholesterol (mmol/L) & $11.4 \pm 1.3$ & $11.9 \pm 2.2$ & $14.0 \pm 1.8$ \\
Total glycerol (mmol/L) & $0.9 \pm 0.1$ & $1.2 \pm 0.2$ & $1.3 \pm 0.2$ \\
HDL cholesterol (mmol/L) & $0.3 \pm 0.06$ & $0.5 \pm 0.03$ & $0.4 \pm 0.04$ \\
Frec glycerol (mmol/L) & $0.2 \pm 0.03$ & $0.2 \pm 0.02$ & $0.2 \pm 0.04$ \\
LDL cholesterol (mmol/L) & $10.8 \pm 1.2$ & $10.9 \pm 2.1$ & $13.5 \pm 1.7$ \\
\hline
\end{tabular}

Values are mean \pm SEM. * liver weight divided by total body weight. " $P<0,05 \mathrm{vs}$. control. *P<0.01 vs. $\mathrm{B}|\mathrm{c}| \mathrm{P}$ and controls.

\section{Blood flow cytometry analysis}

The effect of PAH exposure on circulating inflammatory cells was measured by means of flow cytomery of blood T-lymphocytes, B-lymphocytes, granulocytes 
and macrophages. $\mathrm{B}[\mathrm{a}] \mathrm{P}$ and $\mathrm{B}[\mathrm{e}] \mathrm{P}$ exposure did not influence the levels of circulating inflammatory cells compared to the control group (Table 5.2). Although relative blood granulocytes levels differed between the B[e]P- and B[a]P-exposed animals, comparison of both PAH groups to the control group showed that the levels were not significantly different.

Table 5.2 Flow cytometry analysis of peripheral blood cells.

\begin{tabular}{lccc}
\hline & $\begin{array}{c}\text { Control } \\
(n=5)\end{array}$ & $\begin{array}{c}\text { B[e]P } \\
(n=16)\end{array}$ & $\begin{array}{c}\text { B[a]P } \\
(n=14)\end{array}$ \\
\hline T-Lymphocytes (\%) & $18.8 \pm 1.7$ & $21.9 \pm 1.2$ & $21.8 \pm 1.3$ \\
B-lymphocytes (\%) & $43.0 \pm 1.4$ & $45.8 \pm 1.7$ & $43.5 \pm 1.5$ \\
\hline Granulocytes (\%) & $19.3 \pm 2.4$ & $15.6 \pm 0.8^{*}$ & $20.5 \pm 1.8$ \\
Macrophages (\%) & $15.3 \pm 1.1$ & $15.0 \pm 0.6$ & $13.4 \pm 0.8$ \\
\hline
\end{tabular}

Values are mean \pm SEM. $* P<0.05$ vs. $B|a| P$

- indicates that the cell subsets were determined in two separate staining procedures.

\section{Plaque parameters}

\section{Plaque burden}

In total 188 lesions were analyzed in the aortic arches of 42 mice: 74 lesions in the $\mathrm{B}[\mathrm{e}] \mathrm{P}$-exposed animals $(n=17), 71$ lesions in the B[a]P $(n=16)$ and 43 lesions in the control group $(n=9)$. The location (inner curve of the arch, brachiocephalic trunk, left subclavian artery, and left common catotid artery) and the number of plaques per arch did not differ between the three groups. Most lesions were advanced lesions (173 out of 188). Total plaque area per arch seemed to be highest in the $\mathrm{B}|\mathrm{e}| \mathrm{P}$-exposed mice, followed by the B|a|P group and lowest in the control group although not statistically significant (Figure 5.2A).

The lesions in the thoracic aorta wete predominanty initial lesions. There was no difference in the number of lesions per thoracic aorta segment between the three groups (control: $2.1 \pm 0.5, \mathrm{~B}[\mathrm{c}] \mathrm{P}: 2.9 \pm 0.3, \mathrm{~B}[\mathrm{a}] \mathrm{P}: 2.2 \pm 0.3$ ). Again, total lesion area per segment tended to be higher in $\mathrm{B}[\mathrm{e}] \mathrm{P}$-exposed animals, followed by $\mathrm{B} \mid$ a $] \mathrm{P}$ and controls (Figure 5.2B), but again no statistical significance was reached. Plaque pbenotype

Based on the results from our earlier study, ${ }^{13}$ we focussed on inflammatory plaque parameters in the aortic arch. Plaque macrophage content was not significandy different berween the B[e]P, B $[\mathrm{A}] \mathrm{P}$ and control group $(39.4 \pm 2.9 \%, 44.6 \pm 3.1 \%$ 
A

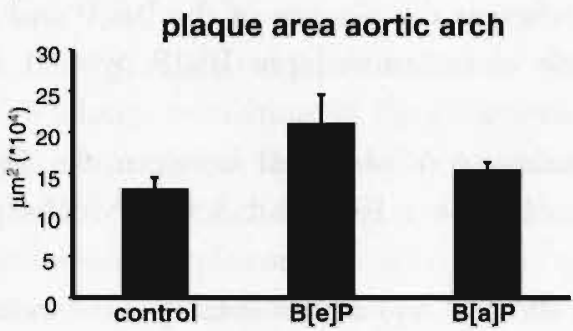

C

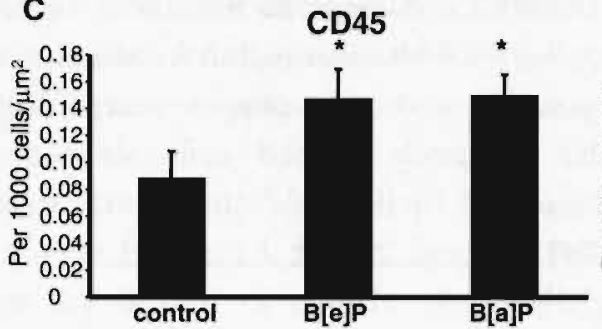

E

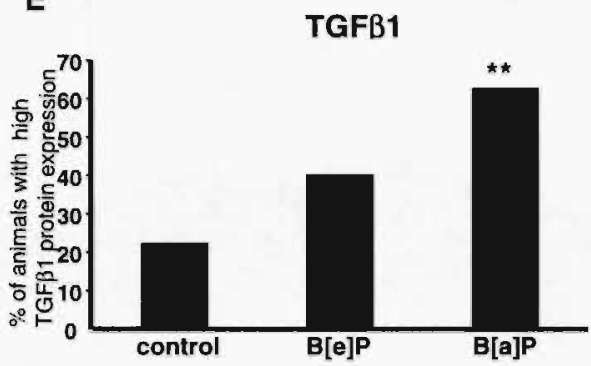

B
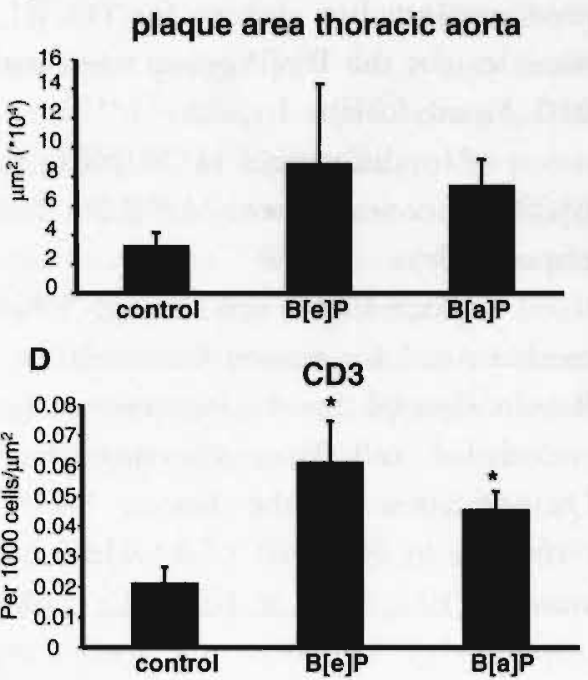

Figure 5.2 Plaque characteristics of control, $\mathrm{B}[\mathrm{e}] \mathrm{P}$ and $\mathrm{B}[\mathrm{a}] \mathrm{P}$-exposed apoE-KO mice. A, mean toral plaque area in the aorie arch, B, mean rotal placue area in the thomeic aora, $C$, total inflammatory cell (CD45) content. D. T-lymphocye (CD3) content, E, semiquantitative TGFß1 protein expression. ${ }^{*} P<0,05$ vs. control, ${ }^{* *} \chi^{2}=7,0, P<0,05 \mathrm{vs.}$ control.

and $37.8 \pm 4.1 \%$, respectively). Plaque total inflammatory cells (CD45 positive cells) were equally high in the $\mathrm{B}[\mathrm{c}] \mathrm{P}$ and $\mathrm{B}[\mathrm{a}] \mathrm{P}$ group, but were significantly enhanced compared to the control group $(P<0.05$, Figure 5.2C). Also, immunohistochemistry showed a clear increase in plaque T-lymphocytes (CD) 3 positive cells) in both $\mathrm{B}[\mathrm{e}] \mathrm{P}_{*}$, and $\mathrm{B}[\mathrm{a}] \mathrm{P}$-exposed animals, as compared to the control animals (Figure 5.3A, B, and C). Quantification of the CD3 positively stained cells per plaque showed that this difference was statistically significant $(P<$ 0.05 , Figure 5.2D).

As an immunomodulating cytokine involved in carcinogenesis and atherogenesis, immunohistochemical staining of TGF $\beta 1$ protein was performed (Figure 5.3D, E, and F). Based on staining intensity, sections of the aortic arches 
were classified as low or high protein expression. The control animals exhibited predominantly low staining for TGF $\beta 1$, whereas the plaques of the $\mathrm{B}[\mathrm{a}] \mathrm{P}$ and to a lesser extent the $\mathrm{B}[\mathrm{e}] \mathrm{P}$ group were mainly classified as high $\left(\mathrm{B}[\mathrm{a}] \mathrm{P}: \chi^{2}=7.0, P<\right.$ 0.05. Figure 5.2E).

No differences in TUNEL staining were observed between the B[e]P, $\mathrm{B}[\mathrm{a}] \mathrm{P}$ and control mice $\left(24 \pm 3.2 \times 10^{-6}, 24 \pm 3.8 \times 10^{-6}, 23 \pm 8.5 \times 10^{-6}\right.$ cells $/ \mu \mathrm{m}^{2}$ respectively).

Since PAHs can damage DNA directly and also indirectly via oxidative mechanisms, we stained for oxidative (8-OHdG) damage in the nuclei of cells. Results showed that the immunoreactivity for $8-\mathrm{OHdG}$ was mainly localized to the endothelial cell layer covering the plaques and the plaque macrophages. Quantification of the plaque 8-OHdG positively stained cells showed no difference in the levels of $8-O H d G$ between the $\mathrm{B}[\mathrm{e}] \mathrm{P}, \mathrm{B}[\mathrm{a}] \mathrm{P}$ and control treated animals $\left(10.2 \pm 1.7 \times 10^{-4}, 10.5 \pm 1.6 \times 10^{-4}\right.$, and $20.0 \pm 1.1 \times 10^{-4}$ cells $/ \mu \mathrm{m}^{2}$ respectively). Moreover, the media underlying the plaques as well as the nondiseased vessel wall was almost completely negative.
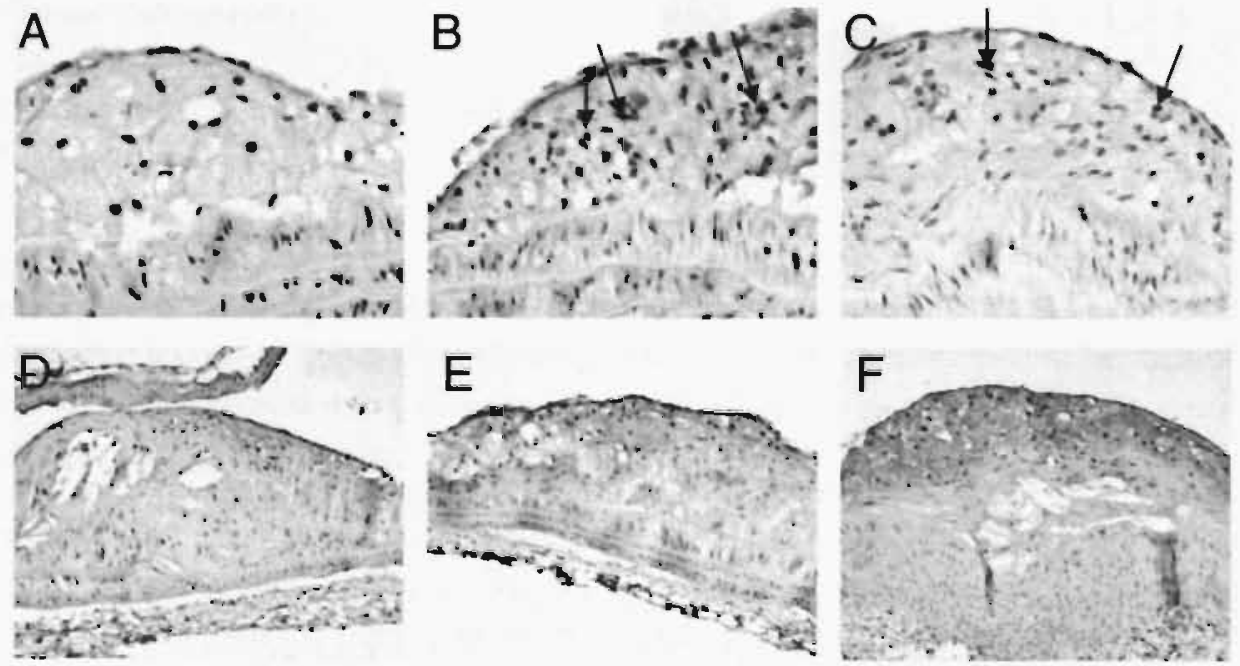

Figure 5.3 Representative plaque characteristics of apoE-KO mice exposed to $\mathrm{B}[\mathrm{a}] \mathrm{P}$, $\mathrm{B}[\mathrm{e}] \mathbf{P}$ or vebiculum (control). Upper row: CD3 staining of plaques in the aotut arch of a control

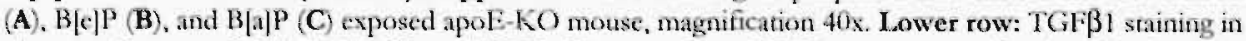
plaques of a control (D), B $|c| \mathrm{P}$ (E), and B $\mid \mathrm{al} P$ (F) cxposed apoE-KO mounc, magnificarion 20x. See also back turnover for color picture. 


\section{Discussion}

The current study was performed to obtain more insight into the role of bulky DNA adduct formation in the progression of $\mathrm{PAH}$-induced atherosclerosis. Our results showed that the non-DNA adduct forming $\mathrm{PAH} B[\mathrm{e}] \mathrm{P}$ was just as potent as its DNA adduct forming structural isomer $\mathrm{B}[\mathrm{a}] \mathrm{P}$ to elicit a local inflammatory atheroscletotic plaque phenotype in apoE-KO mice. We showed that this inflammatory plaque phenotype was not due to modulation of plasma lipid levels. Furthermore, data obtained from immunohistochemical staining did not indicate an additional role for oxidative DNA damage or apoptosis, but an up-regulation of TGF $\beta 1$ protein expression in the plaque macrophages (Figure 5.4).

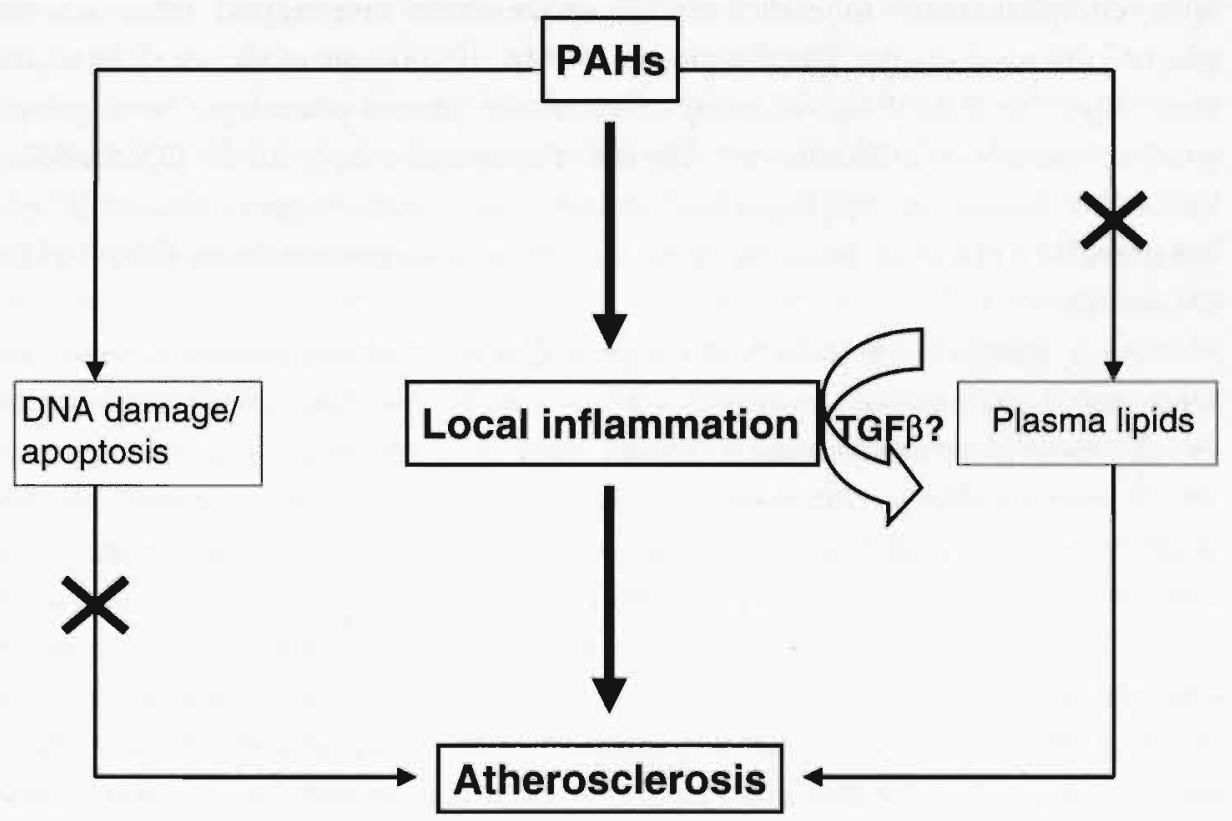

Figure 5.4 Proposed mechanism of PAH-mediated atherosclerosis in apoE-KO mice. A cross $(\mathrm{X})$ indicates the exclusion of a possible route of action.

Several studies have linked PAH-induced DNA adduct formation to human atherogenesis. Increased PAH-DNA adducts were detected in the smooth muscle layers of human atherosclerotic lesions. ${ }^{20,21}$ Furthermore, van Schooten $t$ al. ${ }^{6}$ showed that aromatic DNA adduct levels in the right atrial appendage were related to the severity of coronary artery disease. In line with these findings, Binkova $e t$ al.$^{7.22}$ reported that aortic bulky adduct levels, among which PAH-DNA 
adducts, were higher in subjects with frequent atherosclerotic changes compared to subjects with few atherosclerotic changes. These observations have led to the hypothesis that PAHs may exert their atherogenic capacity via the induction of DNA damage. In the present study, the role of PAH-DNA adduct formation on atherosclerosis in apoE-KO mice was further investigated by comparing the atherogenic capacity of the adduct forming carcinogen B[a]P with the non-adduct forming, non-carcinogen B[e]P.

In previous animal studies, we and others have already demonstrated that the aorta is a potential target tissue for PAH-DNA adducts (chapter 2). ${ }^{12,23}$ In line with these findings we showed that high adduct levels in the aorta of apoE-KO mice chronically exposed to $\mathrm{B}[\mathrm{a}] \mathrm{P}$ were parallelled with an enhanced plaque progression combined with a more inflammatory phenotype. ${ }^{13}$ These observations were complementary to earlier animal studies that investigated atherosclerotic plaque progression after $\mathrm{B}[\mathrm{a}] \mathrm{P}$ exposure. ${ }^{24.25}$ In the present study we showed that both $\mathrm{B}[\mathrm{a}] \mathrm{P}$ and $\mathrm{B}[\mathrm{e}] \mathrm{P}$ significantly affected the plaque phenotype by causing a profound influx of inflammatory cells into the plaques. Because no DNA adducts could be found in B[e]P-treated animals these data suggest that this proinflammatory effect of both $\mathrm{B}[\mathrm{a}] \mathrm{P}$ and $\mathrm{B}[\mathrm{e}] \mathrm{P}$ is independent from DNA adduct formation.

It should be kept in mind however, that PAH-metabolism is associated with the induction of oxidative stress, which has been implicated in the development of atherosclerosis. ${ }^{26-28}$ since $\mathrm{B}[\mathrm{a}] \mathrm{P}$, but not $\mathrm{B}[\mathrm{e}] \mathrm{P}$ triggers cytochrome P450 enzymes that are involved in these oxidative processes, ${ }^{18}$ we expected that $\mathrm{B}[\mathrm{a}] \mathrm{P}$ but not B[e]P would increase oxidative stress in the plaque. The immunoreactivity for 8-OHdG, a marker for intracellular oxidative stress, was mainly located in the endothelial cell lining covering the plaques and in the plaque macrophages, which was in line with the findings observed in cholesterol-fed New Zealand White rabbits. ${ }^{29}$ However, quantification of the amount of plaque cells positive for 8-OHdG did not reveal an additional increase in oxidative DNA damage in the PAH-exposed animals compared with the controls, thereby questioning the importance of oxidative stress in the PAH-modulated inflammatory plaque phenotype. These data are also supported by the absence of a modulating effect of the PAH treatment on plasma lipid levels, as hypercholesterolemia relates to increased oxidative stress. ${ }^{29}$

The results obtained in the present study gave no indication for involvement of bulky DNA adducts nor an increased induction of oxidative stress in PAH-induced atherogenesis. We did find a clear effect on levels of inflammatory cells in the plaques. The capacity of PAHs to modulate immune cell function has also been well documented. ${ }^{30-32}$ It has been reported by several 
groups that $\mathrm{B}[\mathrm{a}] \mathrm{P}$ suppresses $\mathrm{B}$-lymphocyte responses to T-cell-dependent and independent antigens both in vivo and in vitro. ${ }^{33-35}$ It was also reported that low dosages of $\mathrm{B}[\mathrm{a}] \mathrm{P}$ ( $3 \mathrm{mg} / \mathrm{kg}$ day) resulted in an increase in T-lymphocytes, whereas high dosages $(90 \mathrm{mg} / \mathrm{kg}$ day) resulted in a decrease of both $\mathrm{T}$ - and $\mathrm{B}$ lymphocytes. ${ }^{36}$ However, levels of peripheral blood $\mathrm{T}$ - and B-lymphocytes, granulocytes and macrophages were not changed upon PAH treatment, suggesting that the inflammatory plaque phenotype was most likely a local response of the damaged vessel wall. These local effects are further substantiated by the lack of PAH-related changes in liver weight or pathology. These changes were observed in rats exposed to higher dosages of $\mathrm{B}[\mathrm{a}] \mathrm{P} .{ }^{36}$

We can thus conclude that apoE- $\mathrm{KO}$ mice chronically exposed to $\mathrm{B}[\mathrm{a}] \mathrm{P}$ or $\mathrm{B}[\mathrm{e}] \mathrm{P}$ show an enhanced local inflammatory response characterized by atherosclerotic plaques that exhibit increased levels of total inflammatory cells and plaque T-cells. Because TGF $\beta$ has been considered to play a role in the development of both atherosclerosis and cancer, ${ }^{5,37-39}$ and has proven to be modulated by $\mathrm{PAHs},{ }^{40}$ we further investigated the effects of $\mathrm{PAH}$ exposure on TGF $\beta 1$ protein expression in the plaques. In the present study we found that TGF $\beta 1$ protein expression was elevated in the plaque macrophages of $\mathrm{B}[\mathrm{a}] \mathrm{P}-$, and although to a lesser extent also in plaque macrophages of B[e]P-exposed animals compared with the controls. TGF $\beta 1$, a growth factor with dualistic metabolic features, was first recognized as an anti-inflammatory cytokine. It is for example known to inhibit inflammation, proliferation and migration of smooth muscle cells and endothelial cells, ${ }^{41}$ and may thereby decrease the atherosclerotic plaque development. However, other studies have associated TGF $\beta 1$ expression with the development of arterial disease accompanied by hyperplasia of the endothelium, apoptosis and cartilaginous metaplasia of the vascular media. ${ }^{42}$ Likewise, both disease-inhibiting and promoting effects of TGF $\beta$ in the development and progression of cancer have been described. ${ }^{43,44}$ In $\mathrm{B}[\mathrm{a}] \mathrm{P}$-induced skin tumors TGF $\beta 1$ is upregulated and suggested to be responsible for aberrant tissue reconstruction and tumor induction, via a constant reinitiating wound-healing cascade. ${ }^{37}$ However, in primary human hepatocytes TGF $\beta 1$ prevents the induction of CYP1A1 and $-1 \mathrm{~A} 2$ by $\mathrm{B}[\mathrm{a}] \mathrm{P} .{ }^{45}$ Because CYP1A1 and $-1 \mathrm{~A} 2$ are involved in $\mathrm{B}[\mathrm{a}] \mathrm{P}$ metabolism, upregulation of TGF $\beta 1$ could furthermore implicate a feedback mechanism to protect against $\mathrm{B}[\mathrm{a}] \mathrm{P}$ metabolites.

In conclusion, this study has shown that the non-adduct forming $\mathrm{PAH}$ $\mathrm{B}[\mathrm{e}] \mathrm{P}$ elicits an inflammatory plaque phenotype in apoE-KO mice which is comparable to the phenotype induced by the DNA-adduct forming PAH B[a]P. These observations suggest that PAH-DNA adduct formation is not critically involved in PAH-modulated atherogenesis. In contrast, our data indicate that 
PAHs such as $\mathrm{B}[\mathrm{a}] \mathrm{P}$ and $\mathrm{B}[\mathrm{e}] \mathrm{P}$ might exert their effect via a stimulation of a general local inflammatory process, involving an increased influx of proinflammatory cells into the plaques. Although the underlying mechanism remains unclear, the present study suggests a role for TGF $\beta 1$ in this process. 


\section{References}

1. Stary HC: Evolution and progression of atherosclerotic lesions in coronary arteries of children and young adults. Arteriosderosis 1989, 9:119-32

2. Stary H, Blankenhorn D, Chandler A, Glagov S, Insull W, Richardson M, Rosenfeld M, Schaffer S, Schwartz C, Wagner W, Wissler R: A definition of advanced types of atherosclerotic lesions and a histological classification of atherosclerosis. Arteriosdemasis, thrombosis and vascular biology 1995, 15:1513-1531

3. Ross R: Atherosclerosis--an inflammatory disease. N Eng/ J Med 1999, 340:115-126

4. Benditt EP: Evidence for a monoclonal origin of human atherosclerotic plagues and some implications. Circulation 1974, 50:650-652

5. Ross JS, Stagliano NE, Donovan MJ, Breitbart RE, Ginsburg GS: Atherosclerosis and cancer: common molecular pathways of disease development and progression. $A m n Y$ Acad Sci 2001, 947:271-292; discussion 292-273

6. Van Schooten FJ, Hirvonen A, Maas LM, De Mol BA, Kleinjans JC, Bell DA, Durrer JD: Putative susceptibility markers of coronary artery disease: association between VDR genotype, smoking, and aromatic DNA adduct levels in human right atrial tissue. Faseb J $1998,12: 1409-1417$

7. Binkova B, Strejc P, Boubelik O, Stavkova Z, Chvatalova I, Sram RJ: DNA adducts and human atherosclerotic lesions. Int J Hyg Emvinon Health 2001, 204:49-54

8. De Flora S, Izzotti A, Randerath K, Randerath E, Bartsch H, Nair J, Balansky R, van Schooten F, Degan P, Fronza G, Walsh D, Lewtas J: DNA adducts and chronic degenerative disease. Pathogenetic relevance and implications in preventive medicine, Mutat Res 1996, 366:197-238

9. De Flora S, Izzotri A, Walsh D, Degan P, Perrilli GL, Lewtas J: Molecular epidemiology of atherosclerosis. Faseb J 1997, 11:1021-1031

10. Polynuclear aromatic compounds, Part 1, Chemical, environmental and experimental data. LARC Monogr Eval Carinog Risk Cbem Hum 1983, 32:1-453

11. Wakabayashi $\mathrm{K}$ : International Commission for Protection Against Environmental Mutagens and Carcinogens. ICPEMC Working Paper 7/1/3. Animal studies suggesting involvement of mutagen/carcinogen exposure in atherosclerosis. Mutat Res 1990, 239:181187

12. Curfs DMJ, Beckers L, Godschalk RWL, Gijbels MJ, van Schooten FJ: Modulation of plasma lipid levels affects benzo|alpyrene-induced DNA damage in tissues of two hyperlipidemic mouse models. Envimon Mo/ Mulagen 2003, 42:243-249

13. Curfs DMJ, Lutgens E, Gijbels MJ, Kockx MM, Daemen MJAP, van Schooten FJ: Chronic exposure to the carcinogenic compound benzo|alpyrene induces larger and phenotypically different atherosclerotic plaques in apoE-knockout mice. Am j Patbol 2004, 164:101-108.

14. Hankinson O: The aryl hydrocarbon receptor complex. Annu Re; Pbarmacol Toxicol 1995 , 35:307-340

15. van Grevenynghe J. Rion S, Le Ferrec E, Le Vee M. Amiot L. Faucher R, Fardel O: Polycyclic aromatic hydrocarbons inhibit differentiation of human monocytes into macrophages. J immuno/2003, 170:2374-2381

16. Wood AW, Chang RI, Huang MT, Levin W, Lehr RE, Kumar S, Thakker DR, Yagi H, Jerina DM. Conney AH: Mutagenicity of benzo(e)pyrene and triphenylene tetrahydroepoxides and diol-epoxides in bacterial and mammalian cells. Cancer Res 1980, 40:1985-1989

17. Thakker DR, Levin W, Buening M, Yagi H, Lehr RE. Wood AW, Canney AH, Jerina DM: Species-specific cohancement by 7,8-benzotlavone of hepatic microsomal metabolism of benzo|elpyrene 9,10-dihydrodiol to bay-region diol epoxides. Cancer Res 1981, 41:13821396

18. Wood AW, Levin W. Thakker DR, Yagi H, Chang RI, Ryan DE, Themas PE, Dansette PM. Whitaker N. Turujman S, Lehr RE, Kumar S, Jerina DM, Conney A.H: Biological 
activity of benzo[e]pyrene. An assessment based on mutagenic activities and metabolic profiles of the polycyclic hydrocarbon and its derivatives. J Biol Chem 1979, 254:4408-4415

19. Godschalk RW, Maas LM, Van Zandwijk N, van't Veer LJ, Breedijk A, Borm PJ, Verhaert J, Kleinjans JC, van Schooten FI: Differences in aromatic-DNA adduct levels between alveolar macrophages and subpopulations of white blood cells from smokers. Carcinogenesis $1998,19: 819-825$

20. Izzotti A, De Flora S, Petrilli GL, Gallagher J, Rojas M, Alexandrov K, Bartsch H, Lewtas J: Cancer biomarkers in human atherosclerotic lesions: detection of DNA adducts. Cancer Epidemiol Biomarkers Prov 1995, 4:105-110

21. Zhang YJ, Weksler BB, Wang L, Schwartz J, Santella RM: Immunohistochemical detection of polycyclic aromatic hydrocarbon-DNA damage in human blood vessels of smokers and non-smokers. Atberosclenosis 1998, 140:325-331

22. Binkova B, Smerhovsky Z, Strejc P, Boubelik O, Stavkova Z, Chvatalova I, Sram RJ: DNA-adducts and atheroselerosis: a study of accidental and sudden death males in the Czech Republic. Mutat Res 2002, 501:115-128

23. Izzotti A, Camoirano A, Cariglia C, Tampa E, De Flora S: Formation of DNA adducts in the aorta of smoke-exposed rats, and modulation by chemopreventive agents. Mutat Res 2001, 494:97-106

24. Albert RE, Vanderlaan M, Burns F, Nishizumi M: Effect of carcinogens on chicken atherosclerosis. Cancer Res 1977, 37:2232-2235

25. Bond JA, Gown AM, Yang HI, Bendit EP, Juchau MR: Further investigations of the capacity of polynuclear aromatic hydrocarbons to elicit atherosclerotic lesions. J Toxicol Emviron Healtb 1981, 7:327-335

26. Burczynski ME, Lin HK, Penning TM: Isoform-specific induction of a human aldo-keto reductase by polycyclic aromaric hydrocarbons (PA.Hs), electrophiles, and oxidarive stress: implications for the alternative pathway of $\mathrm{PAH}$ activation catalyzed by human dihydrodiol dehydrogenase. Camor Res 1999, 59:607-614

27. Penning TM, Burczynski ME, Hung CF, McCoull KD, Palackal NT, Tsuruda LS: Dihydrodiol dehydrogenases and polycyclic aromatic hydrocarbon activation: generation of reactive and redox active o-quinones. Chem Res Toxicol 1999, 12:1-18

28. Martinet W, Knaapen MW, De Meyer GR, Herman AG, Kockx MM: Elevated levels of oxidative DNA damage and DNA repair enzymes in human atherosclerotic plaques. Cinulation 2002, 106:927-932

29. Martinet W, Knaapen MW, De Meyer GR, Herman AG, Kockx MM: Oxidative DNA damage and repair in experimental atherosclerosis are reversed by dietary lipid lowering. Cin Res 2001, 88:733-739

30. Burchici SW, Hadley WM, Barton SI, Fincher RH, Lauer LD, Dean JH: Persistent suppression of humoral immunity produced by 7,12-dimethylbenz(A)anthracene (DMBA) in BGC3F1 mice: correlation with changes in spleen cell surface markers detected by flow cytometry. Int j Immenopharmacol 1988, 10:369-376

31. Ladics GS, Kawabata TT, White KL. Jr.: Suppression of the in vitro humoral inmune response of mouse splenocytes by 7,12-dimethylbenz[a]anthracene merabolites and inhibition of immunosuppression by alpha-naphthoflavone. Toxical App/ Pbarmacol 1991, $110: 31-44$

32. Holladay SD, Smith B]: Benzo[a]pyrene-induced alterations in total immune cell number and cell-surface antigen expression in the thymus, spicen and bone matrow of $\mathrm{B} 6 \mathrm{C} 3 \mathrm{~F} 1$ mice. Vet Hum Toxicol 1995, 37:99-104

33. Dean JH, Luster MI, Boorman GA, Lauer I.D, Leubke RW, Lawson L: Selective immunosuppression resulting from exposure to the carcinogenic congener of benzopyrene in B6C3F1 mice. Clin Exp Immunol 1983, 52:199-206

34. White KI, Jr., Holsapple MP: Direct suppression of in vitro antibody producrion by mouse spleen cells by the carcinogen benzo(a)pyrene but not by the noncarcinogenic congener benzo(e)pyrene. Canar Res 1984, 44:3388-3393 
35. White KL, Jr., Lysy HH, Holsapple MP: Immunosuppression by polycyclic aromatic hydrocarbons: a structure-acrivity relationship in $\mathrm{B} 6 \mathrm{C} 3 \mathrm{~F} 1$ and $\mathrm{DBA} / 2$ mice. Immunapharmacology 1985, 9:155-164

36. De Jong WH, Kroese ED, Vos JG, Van Loveren H: Detection of immunotoxicity of benzo|a|pyrene in a subacute toxicity study after oral exposure in rats. Taxicol $S_{a}$ 1999, 50:214-220

37. Mallat Z, Gojova A, Marchiol-Fournigault C, Esposito B, Kamate C, Merval R, Fradelizi D, Tedgui A: Inhibition of transforming growth factor-beta signaling accelerates atherosclerosis and induces an unstable plaque phenotype in mice. Cin Res 2001, 89:930934

38. Lutgens E, Gijbels M, Smook M, Heeringa P, Gotwals P, Koteliansky VE, Daemen MJ: Transforming growth factor-beta mediates balance between inflammation and fibrosis during plaque progression. Arteriascler Thromb V asc Biol 2002, 22:975-982

39. Wakefield $\mathrm{LM}$, Roberts $\mathrm{AB}$ : TGF-beta signaling: positive and negative effects on tumorigenesis. Carr Opin Genet Dev 2002, 12:22-29

40. Sherman JH, Miller ML, Albert RE, Baxter CS: Dose- and time-dependent expression of transforming growth factor-beta $1 \mathrm{mRNA}$ and protein in mouse epidermis and papillomas after repeated topical application of benzo[a|pyrene. Mo/ Carcinog 1993, 8:264-271

41. McCaffrey TA: TGF-betas and TGF-beta receptors in arherosclerosis. Cytokine Growtb Factor Rev 2000, 11:103-114

42. Schulick AH, Taylor AJ, Zuo W, Qiu CB, Dong G, Woodward RN, Agah R, Roberts AB, Virmani R, Dichek DA: Overexpression of transforming growth factor beta1 in arterial endothelium causes hyperplasia, apoptosis, and cartilaginous metaplasia. Proc Natl Acad Sa US A 1998, 95:6983-6988

43. Wieser R: The transforming growth factor-beta signaling pathway in tumorigenesis. Cum Opin Oncol 2001, 13:70-77

44. Parkinson $\mathrm{K}$, Balmain A: Chalones revisited-a possible role for transforming growth factor beta in tumour promotion. Carcinogenesis 1990, 11:195-198

45. Abdel-Razzak Z, Corcos L, Fautrel A, Campion JP, Guillouzo A: Transforming growth factor-beta 1 down-regulates basal and polycyclic aromatic hydrocarbon-induced cytochromes P-450 $1 \mathrm{~A} 1$ and $1 \mathrm{~A} 2$ in adult human hepatocytes in primary culture. Mol Pharmacol 1994, 46:1100-1110 



\section{Chapter 6}

\section{Upregulation of TGF $\beta$ gene expression in the aortic arch of apolipoprotein $\mathrm{E}$ knockout mice after acute exposure to benzo[a]pyrene}

Daniëlle M.J. Curfs, Menno P.J. de Winther, Daniëlle M.F.A. Pachen, Marjan Smook, Mat J.A.P. Daemen, Frederik J. van Schooten 


\section{Abstract}

Chronic exposure to benzo[a]pyrene $(\mathrm{B}[\mathrm{a}] \mathrm{P})$ results in an inflammatory atherosclerotic plaque phenotype in apoE-KO mice. The present study was conducted to obtain more insight in the acute effect of $\mathrm{B}[\mathrm{a}] \mathrm{P}$ exposure on gene expression of inflammatory cytokines, especially TGF $\beta$, in the aorta of apoE-KO mice with mild atherosclerosis. Twenty four male apoE-KO mice (17 weeks of age) were given orally one dose of $5 \mathrm{mg} / \mathrm{kg}$ bw B[a]P or the vehicle tricaprylin. One week after dosing blood was collected by tail bleeding for the assessment of peripheral immunological cells. A day later animals were killed and aortas were either used for the phenotyping of the atherosclerotic plaque development or the expression of the anti-inflammatory cytokine TGF $\beta$, the macrophage scavenger receptor CD68 and other pro-inflammatory associated cytokines such as MCP1, TNF $\alpha$ and Il-6. Results showed that relative levels of peripheral T-lymphocytes were slightly decreased upon $B[a] P$ exposure $(B[a] P: 14.7 \pm 1.2 \%$ vs. control: 17.2 $\pm 0.7 \%, P<0.05)$. As expected, acute exposure to $\mathrm{B}[\mathrm{a}] \mathrm{P}$ did not modulate atherosclerotic plaque development in the aortic arch, shown by the fact that there were no differences in number, size and location of the plaques compared with the unexposed control animals. Furthermore, levels of plaque total inflammatory cells, T-cells and macrophages were not modulated after a single dose of $\mathrm{B}[\mathrm{a}] \mathrm{P}$. However, relative gene expression profiling showed that TGF $\beta$ was significantly upregulated in the aorta of the $\mathrm{B}[\mathrm{a}] \mathrm{P}$-exposed animals $(1.0 \pm 0.2$ and $0.5 \pm 0.2, P<$ $0.05)$. CD68, TNF $\alpha, \mathrm{MCP} 1$ and $\mathrm{Il}-6$ were not significantly modulated by the B[a]P exposure (CD68: $3.3 \pm 0.8$ and $1.5 \pm 0.4, P=0.06$; TNF $\alpha: 8.0 \pm 1.0 \times 10^{4}$ and 4.2 $\pm 1.0 \times 10^{-4}, P=0.08$; MCP1: $1.4 \pm 1.1 \times 10^{-3}$ and $0.4 \pm 0.1 \times 10^{-3}, P=0.45$; Il- 6 ; $1.4 \pm 1.2 \times 10^{-4}$ and $1.3 \pm 0.7 \times 10^{-4}, P=0.83$, respectively for $\mathrm{B}[\mathrm{a}] \mathrm{P}$ and control treatment). In conclusion, a single oral dose of $\mathrm{B}[\mathrm{a}] \mathrm{P}$ results in an upregulation of TGF $\beta$ in the aorta even before the $\mathrm{B}[\mathrm{a}] \mathrm{P}$-induced inflammatory plaque phenorype has been established. 


\section{Introduction}

The most widely believed theory concerning the pathogenesis of atherosclerosis states that it is a progressive inflammatory disease of the large arteries. ${ }^{1,2}$ Monocytes are recruited into the damaged vessel wall where they differentiate into macrophages that take up lipids, thereby becoming lipid-loaden macrophages or foam cells. Medial smooth muscle cells start proliferating and T-lymphocytes and more macrophages migrate to the site of injury. The development of the atherosclerotic lesions is orchestrated by cytokines (e.g. TNF $\alpha, \mathrm{Il}-6$ ), chemokines (e.g. MCP1) and growth factors (e.g. TGF $\beta$ ) ${ }^{3,4}$

Among the risk factors for developing atherosclerosis is the exposure to polycyclic aromatic hydrocarbons $(\mathrm{PAHs}) .{ }^{5} \mathrm{PAHs}$ are the product of incomplete combustion of organic materials and are abundantly present in the environment. ${ }^{6}$ Benzo[a]pyrene, a well known PAH, has proven to be both carcinogenic and atherogenic in animal models ${ }^{7,8}$ The specific role of $\mathrm{B}[\mathrm{a}] \mathrm{P}$ in atherogenesis however is unclear. B[a]P is lipid soluble and it is believed that upon entering the blood it can reach the vessel wall via transportation in lipoproteins.' In previous studies we have shown that B[a]P induces high levels of BPDE-DNA adducts in the aorta of apolipoprotein $\mathrm{E}$ knockout (apoE-KO) mice, ${ }^{10,11}$ together with an enhanced progression of atherosclerosis. ${ }^{12}$ The atherosclerotic plaques exhibited a more inflammatory phenotype characterized by T-lymphocytes and macrophages upon $\mathrm{B}[\mathrm{a}] \mathrm{P}$ treatment. However, unpublished data from our group showed that the non-adduct forming PAH benzo[e]pyrene (B[e]P), when administered for 24 weeks, was just as potent as $\mathrm{B}[\mathrm{a}] \mathrm{P}$ to elicit an inflammatory atherosclerotic plaque phenotype, suggesting that the DNA-adduct formation is not the main route of action in PAH-induced arherogenesis. This PAH-induced local inflammation was associated with upregulation of transforming growth factor $\beta 1$ (TGF $\beta 1$ ) protein expression in the plaque macrophages of the chronically exposed apoE-KO mice (unpublished data). TGF $\beta 1$, a pleiotropic growth factor, is primarily recognized in the development of atherosclerosis as an anti-inflammatory cytokine. ${ }^{13}$ From that data it remained unclear whether the increase in TGF $\beta 1$ protein expression in the plaque macrophages was caused by the $\mathrm{B}[\mathrm{a}] \mathrm{P}$ exposure or a consequence of the inflammatory changes in plaque phenotype. The present study was undertaken to investigate the acute effect of a single dose of $B[a] P(5 \mathrm{mg} / \mathrm{kg} \cdot \mathrm{bw})$ on arterial mRNA expression of TGF $\beta 1$ in apoE-KO mice, which had already developed mild atherosclerosis. Supplementary, to gain more insight in the B[a]P-mediated inflammatory response, we also measured mRNA expression of CD68, TNF $\alpha$, MCP1 and 11-6, factors known to be involved in inflammation and progression of atherosclerosis. 


\section{Materials and Methods}

\section{Animal treatment}

Twenty-four male apoE-KO mice, 5 weeks of age, were purchased from IFFA CREDO S.A. (a Charles River Co., Lyon, France). Mice were housed under standard conditions at the animal facility of the University of Maastricht. Water and normal chow were provided ad libitum.

A homogenous solution of $0.5 \mathrm{mg} \mathrm{B}[\mathrm{a}] \mathrm{P}$ (B1760, Sigma) / $\mathrm{ml}$ tricaprylin (103104, ICN) was produced by first dissolving the $\mathrm{B}[\mathrm{a}] \mathrm{P}$ in acetone and then adding it to the tricaprylin. Finally, the acetone was removed from the solution by evaporation under nitrogen for 5 hours. Mean body weight of all animals at 17 weeks was $26.2 \pm 0.5 \mathrm{~g}$, all animals received a single oral dose of $5 \mathrm{mg} / \mathrm{kg}$ bw B[a]P or tricaprylin after an overnight fasting period. One week after dosing all animals were killed and tissue was further processed.

\section{Flow cytometry}

One day before the animals were sacrificed, approximately $50 \mu l$ of heparinized blood was collected via tail bleeding. Erythrocytes were removed by hypotonic lysis with $\mathrm{NH}_{4} \mathrm{Cl}$. T and B-lymphocytes were double stained with CD3-FITC (17A2) or CD45RB-PE (RA3-6B2) respectively. Granulocytes and macrophages were stained with antibodies Ly-6G and Ly-6C FITC-labeled (RB6-8C5) and CD11b/Mac-1 PE-labeled (M1/70) respectively. All antibodies were supplied by BD-Pharmingen. Flow cytometry was performed using a FACS Calibur and the results were analyzed with the CellQuest sofrware (BD-Science).

\section{Tissue processing}

On euthanasia, all animals were anesthetized with Nembutal $0.5 \mathrm{ml} / \mathrm{kg}$ ip. For the assessment of atherosclerotic plaque development, the arterial tree of 10 mice was perfused with $0.9 \% \mathrm{NaCl}$ containing $20 \%$ nirroprusside (3 minutes) and subsequently with $1 \%$ phosphate-buffered paraformaldehyde ( $\mathrm{pH} 7.4,3$ minutes) via a catheter in the apex of the heart. The complete arterial tree was excised and fixed overnight in $1 \%$ phosphare-buffered paraformaldehyde. The aortic arch, thomeic and abdominal aorta were embedded in paraffin and subsequently $4 \mu \mathrm{m}$ sections were cut.

For the assessment of gene expression profiles, aortic arches of the other mice $(n=14)$ were taken out immediately, rinsed ance in $0.9 \% \mathrm{NaCl}\left(4^{\circ} \mathrm{C}\right)$ and snap frozen in liquid nitrogen. Samples were kept at $-80 \circ \mathrm{C}$ until further processing. 


\section{Atberosclerosis assessment}

For morphometrical analysis, 4 section of the aortic arch, each separated by $20 \mu \mathrm{m}$, were stained hematoxylin and eosin. Plaque area was measured using a computerized morphometry system (Quantimet 570, Leica). Total inflammatory cells, T-lymphocytes, and macrophages were stained using the antibodies CD45 (1:50, Pharmingen), CD3 (1:80, Labvision), and Mac-3 (1:30, BP-Pharmingen) respectively. Total inflammatory cell content, T-lymphocyte content and macrophage content were quantified by counting the number of CD 45, CD 3 and Mac-3 positive cells, divided by the total number of cells per plaque.

\section{Relative Quantitative gene expression}

For gene expression, total RNA was isolated from the aortic arch using the RNeasy ${ }^{\circledR}$ mini kit (Qiagen) according to the manufacturer's instructions. Quantity of each RNA sample was measured spectrophotometrically, and integrity was determined by a bioanalyzer (Agilent Technologies Netherlands B.V., The Netherlands). RT-PCR reactions using the SuperScript ${ }^{T M}$ II RNase H- Reverse Transcriptase (Invitrogen) were performed to obtain cDNA. Primer-probe sets for TNF $\alpha$, MCP1, TGF $\beta$, CD68, and Il-6 were designed using Primer Express version 1.5 (Applied Biosystems, Foster City, California, USA) using default settings. To standardize the total amount of cDNA, GAPdH was used as a housekeeping gene. Samples were assayed in duplicate on the ABI PRISM 7700 Sequence Detector (Applied Biosystems, Foster City, California, USA) using the qPCR Mastermix (Eurogentec, Seraing, Belgium), $25 \mathrm{ng}$ of $\mathrm{cDNA}, 300 \mathrm{nM}$ primer and $200 \mathrm{nM}$ probe. Data were analyzed using the Sequence Detection Software version 1.9 (Applied Biosystems) by means of the Relative Standard Curve Method (Applied Biosystems).

\section{Statistical Analysis}

All data were analyzed using the non-parametric Mann-Whitney U test. Two independent investigators who were blinded for the exposure protocol performed histological analyses. Inter- and intra observer variation was less than $10 \%$. Staristical significance was set at $P<0.05$.

\section{Results}

\section{Flow cytometry}

One day before the animals were sacrificed, levels of peripheral blood immunological cells were determined by means of flow cytometry. Results showed 
that the relative levels of blood B-lymphocytes, macrophages and granulocytes were not changed after a single dose of $\mathrm{B}[\mathrm{a}] \mathrm{P}$. T-lymphocytes were lower in the B[a]P exposed animals compared to the control treatment $(P<0.05$, Table 6.1).

Table 6.1 Flow cytometry analysis of peripheral blood cells.

\begin{tabular}{ccc}
\hline T-Lymphocytes (\%) & $\begin{array}{c}\text { Control } \\
(n=11)\end{array}$ & $\begin{array}{c}\text { B [a]P } \\
(n=11)\end{array}$ \\
\hline B-lymphocytes (\%) & $17.2 \pm 0.7$ & $14.7 \pm 1.2^{*}$ \\
\hline Granulocytes (\%) & $44.4 \pm 3.3$ & $41.7 \pm 2.5$ \\
Macrophages (\%) & $5.4 \pm 0.7$ & $6.1 \pm 0.8$ \\
\hline
\end{tabular}

Values are mean \pm SEM. * $p<0.05$ vs. Control.

- indicates that the cell subsets were determined in two separate staining procedures.

\section{Atherosclerosis assessment}

Aortic arches of 10 animals were used for the assessment of atherosclerotic plaques $(n=28)$. All 10 mice had developed mild atherosclerosis regardless of the exposure. As expected of the short period between dosing and evaluation, mean total atherosclerotic lesions area per arch did not differ between B[a]P and control treated animals $\left(48,047 \pm 13,959\right.$ and $33,429 \pm 8,159 \mu^{2}$ respectively). Immunohistochemical staining revealed that plaque total inflammatory cells (CD45 positive cells) and plaque $T$-lymphocytes (CD3 positive cells) were not influenced by the single treatment of $\mathrm{B}[\mathrm{a}] \mathrm{P}(\mathrm{CD} 45: 10.3 \pm 1.3$ and $9.7 \pm 2.2 \% ; \mathrm{CD} 3: 0.98 \pm$ 0.45 and $1.0 \pm 0.45 \%$, respectively). Furthermore, the macrophage content of the plaques was not significantly modulated upon the single oral dose of $\mathrm{B}[\mathrm{a}] \mathrm{P}$ (B[a]P: $88.7 \pm 2.9$ and control: $90.3 \pm 2.4 \%$ ).

\section{$m R N A$ expression levels}

Relative gene expression levels of CD68, TGF $\beta, \mathrm{MCP} 1$, TNF $\alpha$, and Il-6 were determined by means of real time PCR. TGF $\beta$ expression was significantly higher in the B[a]P-exposed animals compared to the controls $(1.0 \pm 0.2$ and $0.5 \pm 0.2, P$ $<0.05$, Figure 6.1A). CD68 (3.3 \pm 0.8 and $1.5 \pm 0.4, P=0.06$, Figure 6.1B), TNF $\alpha$ $\left(8.0 \pm 1.0 \times 10^{4}\right.$ and $4.2 \pm 1.0 \times 10^{-4}, P=0.08$, Figure 6.1C), MCP1 $\left(1.4 \pm 1.1 \times 10^{-3}\right.$ and $0.4 \pm 0.1 \times 10^{-3}, P=0.45$, Figure 6.1D) and Il-6 $\left(1.4 \pm 1.2 \times 10^{-4}\right.$ and $1.3 \pm 0.7 \times$ $10^{4}, P=0.83$, Figure $\left.6.1 \mathrm{E}\right)$ were not modulated by the B $[\mathrm{a}] \mathrm{P}$ exposure. 

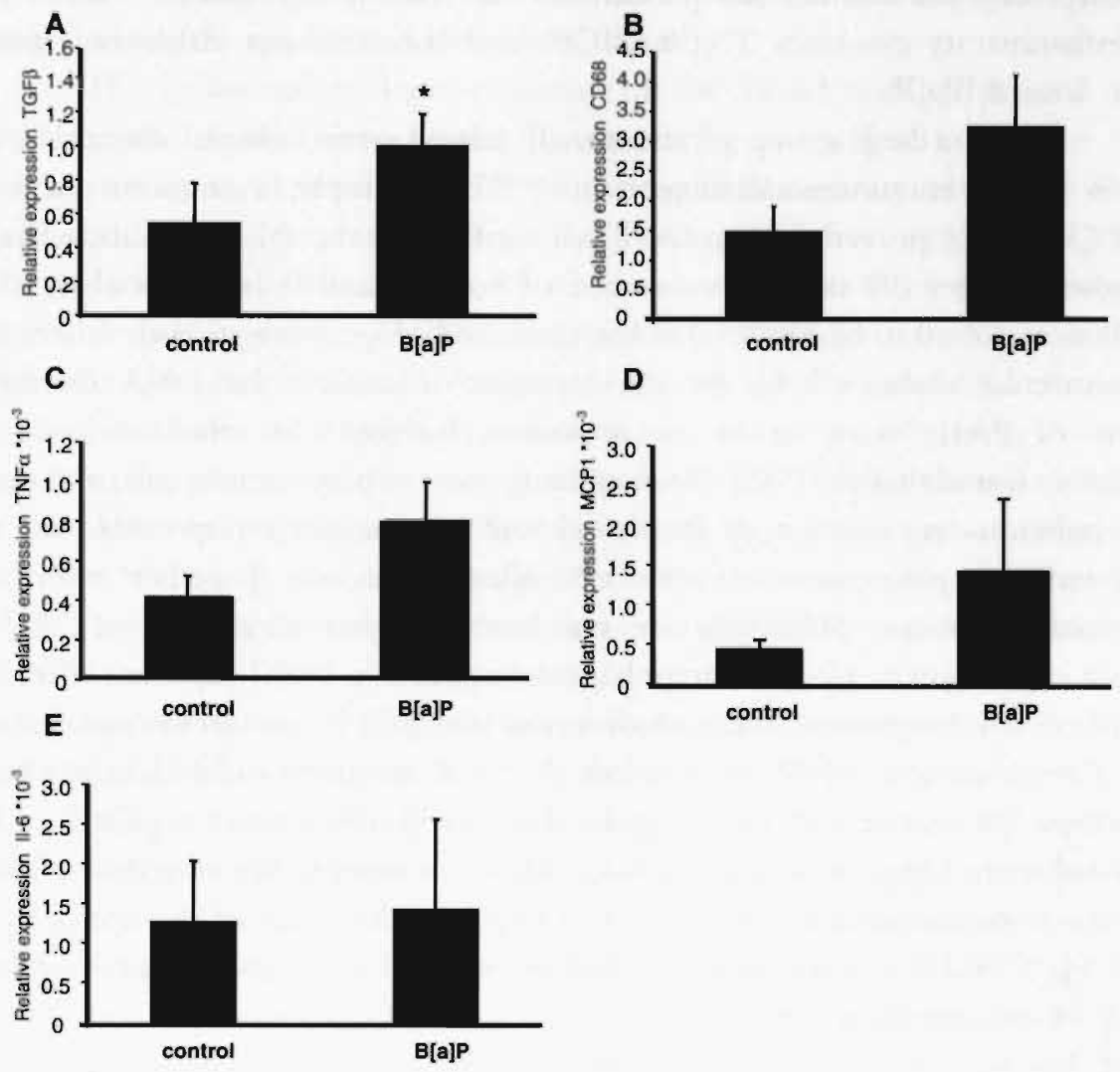

Figure 6.1 Aortic mRNA expression levels in apoE-KO mice after acute exposure to $5 \mathrm{mg} / \mathrm{kg}$.bw B[a]P. Calculations performed by means of the Relative Standard Curve Method (Applied Biosystems) using GNPDH as the housckeeping gene. ${ }^{*} P<0.05$.

\section{Discussion}

The present study was performed to obtain more insight first of all into the role of TGF $\beta$ and the macrophage scavenger receptor CD68 in the plaque specific B[a] $\mathrm{P}$ modulated inflammatory response in apoE-KO mice. Other inflammatory markers such as TNF $\alpha$, MCP1 and Il-6 were also assessed to obtain more insight in regulation of the $\mathrm{B}[\mathrm{a}] \mathrm{P}$-induced inflammatory plaque phenotype that was already observed after chronic exposure. ${ }^{12}$ Results showed that the single oral dose of $\mathrm{B}[\mathrm{a}] \mathrm{P}$ resulted in a slight decrease of circulating T-lymphocytes. However, atherosclerotic plaque size and phenotype were not changed upon a single dose of B[a]P. Moreover, arterial TGF $\beta$ gene expression was significantly upregulated in 
the B[a]P-exposed animals independent of the macrophage marker CD68. The pro-inflammatory cytokines TNF $\alpha, \mathrm{MCP} 1$ and Il- 6 were not influenced after a single dose of $\mathrm{B}[\mathrm{a}] \mathrm{P}$.

PAHs, a large group of structurally related environmental chemicals, are known to have immunomodulating effects. ${ }^{14}{ }^{16}$ For example, low concentrations of $\mathrm{B}[\mathrm{a}] \mathrm{P}(3 \mathrm{mg} / \mathrm{kg}$ ) proved to increase T-cell numbers in the spleen of rats, whereas at higher dosages $(90 \mathrm{mg} / \mathrm{kg})$ a decrease of both T- and B-cells was observed. ${ }^{15}$ PAHs were found to be involved in the onset and progression of both cancer and cardiovascular diseases. ${ }^{17}$ In the development of cancer, the DNA damaging effects of PAHs seem to be an important feature. ${ }^{18}$ In atherosclerosis, we previously found that the PAH-DNA adducts seem to play a minor role, and that a local inflammatory reaction of the vessel wall is most likely responsible for the $\mathrm{B}[\mathrm{a}] \mathrm{P}$-induced progression of the atherogenic process. Together with this inflammatory plaque phenotype we observed a higher expression of TGF $\beta 1$ protein expression in plaque macrophages after chronic B[a]P exposure (data not published). In the present study we observed that TGF $\beta$ was already upregulated after a single dose of $\mathrm{B}[\mathrm{a}] \mathrm{P}$, even before the $\mathrm{B}[\mathrm{a}] \mathrm{P}$-mediated inflammatory plaque phenotype has manifested. This suggests that TGF $\beta$ may act as a regulator of the PAH-induced change in atherosclerotic plaque phenotype. We observed a slight decrease in peripheral T-lymphocytes that might be the result of the upregulation of TGF $\beta .{ }^{19}$ TGF $\beta$ is recognized as a dualistic anti-inflammatory cytokine involved in cell growth, proliferation and differentiation, ${ }^{20}$ and disruption of T-cell derived TGF $\beta$ has been linked to the acceleration of atherosclerosis characterized by a more inflammatory plaque phenotype. ${ }^{13,21,22}$ However, from PAH-induced skin cancer we know that TGFB1 mRNA as well as the actual protein is upregulated after $B[a] P$ exposure ${ }^{23,24}$ It is suggested that the underlying mechanism of this PAH-induced skin cancer is some kind of wound healing artempt in which TGF $\beta 1$ plays a regulatory role especially in cell growth, however resulting in tumor promorion. ${ }^{24}$ On the other hand, TGF $\beta 1$ is also suggested to inhibit the drug metabolizing cytochrome $\mathrm{P} 450$ enzyme system, crucial in PAH metabolism. ${ }^{25}$ Thus, our data suggest that the upregulation of TGF $\beta$ in the aorta after B[a]P exposure is a counterregulation of the pro-inflammatory response induced by $\mathrm{B}[\mathrm{a}] \mathrm{P}$ and to inhibit B/a]P metabolism and stimulate repair of the induced ressel wall damage.

Since the results of our chronic B[a]P exposure study showed that the increased TGF $\beta 1$ protein expression was located to the plaque macrophages we also investigated the mRNA expression of the macrophage marker CD68 in the aora. Howerer, gene expression of CD68 was not significandy modulated due to 
acute $\mathrm{B}[\mathrm{a}] \mathrm{P}$ exposure. This indicates that the increase in TGF $\beta$ gene expression was not merely the result of an increase in CD68.

The inflammatory local response of the vessel wall to chronic B[a]P exposure, was further investigated by measuring the effects of acute $\mathrm{B}[\mathrm{a}] \mathrm{P}$ exposure on gene expression levels of the pro-inflammatory cytokines TNF $\alpha$, MCP1 and Il-6, and the number of plaque T-cells, which were not altered. Tumor necrosis factor (TNF) was initially described as an inducer of cell death in murine tumors. ${ }^{4}$ In atherogenesis, TNF $\alpha$ is secreted by activated macrophages and as a result macrophages, endothelial cells and smooth muscle cells are activated to secrete chemokines such as MCP1, which in turn attract monocytes to the site of injury, thereby promoting the atherogenic process. Il- 6 is a late immune response cytokine involved in systemic inflammation and the increase of atherosclerotic lesion size..$^{4,26}$ As expected, no acute $B[a] P$ effect was found on the gene expression of Il-6. Surprisingly, the results showed that early pro-inflammatory cytokines such as TNF $\alpha$ and MCP1 were also not modulated upon B[a]P treatment.

In conclusion, an upregulation of the anti-inflammatory cytokine TGF $\beta$, most likely CD 68 independent, is one of the first reactions of the vessel wall upon acute $\mathrm{B}[\mathrm{a}] \mathrm{P}$ exposure. Moreover, we show that the earlier reported proinflammatory phenotype induced by chronic $\mathrm{B}[\mathrm{a}] \mathrm{P}$ exposure is not preceded by an acute increase in gene expression levels of the pro-inflammatory cytokines TNF $\alpha$, $\mathrm{MCP} 1$ or $\mathrm{Il}-6$, at least not in the time window we investigated. 


\section{References}

1. Ross R: Atherosclerosis-an inflammatory disease. N Engl/ Med 1999, 340:115-126

2. Ross R: The pathogenesis of atherosclerosis; a perspective for the 1990s. Nature 1993, 362:801-809

3. Libby P, Sukhova G, Lee RT, Galis ZS: Cytokines regulare vascular functions related to stability of the atherosclerotic plaque. J Cardiovasc Pbarmacol 1995, 25 Suppl 2:S9-12

4. Young JL, Libby P, Schonbeck U: Cytokines in the pathogenesis of atherosclerosis. Thromb Haemost 2002, 88:554-567

5. Binkova B, Smerhovsky Z, Strejc P, Boubelik O, Stavkova Z, Chvatalova I, Sram RJ: DNA-adducts and atherosclerosis: a study of accidental and sudden death males in the Czech Republic. Mutat Res 2002, 501:115-128

6. Polynuclear aromatic compounds, Part 1, Chemical, environmental and experimental data. IARC Monogr Eval Carinog Risk Chem Hum 1983, 32:1-453

7. Culp SJ, Warbritton AR, Smith BA, Li EE, Beland FA: DNA adduct measurements, cell proliferation and tumor mutation induction in relation to rumor formation in $\mathrm{B} 6 \mathrm{C} 3 \mathrm{~F} 1$ mice fed coal tar or benzo[a|pyrene. Carinogenesis 2000, 21:1433-1440

8. Wakabayashi $\mathrm{K}$ : International Commission for Protection Against Environmental Mutagens and Carcinogens. ICPEMC Working Paper 7/1/3. Animal studies suggesting involvement of mutagen/carcinogen exposure in atherosclerosis. Mutat Res 1990, 239:181187

9. Stavenow L, Pessah-Rasmussen H: Effects of polycyclic aromatic hydrocarbons on proliferation, collagen secretion and viability of arterial smooth muscle cells in culture. Artery 1988, 15:94-108

10. Curfs DMJ, Beckers L, Godschalk RWL, Gijbels MJ, van Schooten FJ: Modulation of plasma lipid levels affects benzo[a|pyrene-induced DNA damage in tissues of two hyperlipidemic mouse models. Emiron Mol Mutagen 2003, 42:243-249

11. Godschalk R, Curfs DMJ, Bartsch H, van Schooten FJ, Nair J: Benzo[alpyrene enhances lipid peroxidation induced DNA damage in aorta of apolipoprotein E knockout mice. Free Radic Res 2003, 37:1299-1305

12. Curfs DM, Lutgens E, Gijbels MJ, Kockx MM, Daemen MJ, Van Schooten FJ: Chronic Exposure to the Carcinogenic Compound Benzo[a]Pyrene Induces Larger and Phenotypically Different Arherosclerotic Plaques in ApoE-Knockout Mice. AmJ Pathol 2004. 164:101-108

13. Mallat Z, Gojova A, Marchiol-Fournigault C, Esposito B, Kamate C, Merval R, Fradelizi $D$, Tedgui $A$ : Inhibition of transforming growth facror-beta signaling accelerates atherosclerosis and induces an unstable plaque phenotype in mice. Cin Res 2001, 89:930934

14. Holiaday SD, Smith BJ: Benzoja|pyrene-induced atterations in total immune cell number and cell-surface antigen expression in the thymus, spleen and bone marrow of $\mathrm{B} 6 \mathrm{C} 3 \mathrm{~F} 1$ mice. Vof Ham Toxim/ 1905, 37:99-104

15. De Jong WH, Krocse ED, Vos JG, Van Loveren H: Detection of immunotoxicity of benzo|a|pyrene in a subacuic toxicity study after onal exposure in rats. Toxicol So 1999 , 50:214-220

16. White KI, Jr., Holsapple MP: Direct suppression of in vitro antibody production by mouse spleen cells by the carcinogen benzo(a)pyrene but not by the noncarcinogenic congener benzo(e)pyrene. Canor Res 1984, 44:3388-3393

17. Harisen ES: Intemational Commission for Protection Against Environmental Mutagens and Carcinogens. ICPEMC Working Paper $7 / 1 / 2$. Shared risk fucrors for cancer and atherosclerosis-a review of the epidenialogical evidence. Matat Res 1900, 230:163-179

18. Pfeifer GP. Denissenko MIF. Olivier M. Tretyakova N. Hecht SS, Hainaut P: Tobacco smoke carcinogens, DNA damage and p53 mutations in smoking-associaied cancers. Oncogene 2002, 21:7435-74,5! 
19. Hodge SJ, Hodge GL, Reynolds PN, Scicchitano R, Holmes M: Increased production of TGF-bera and apoptosis of $\mathrm{T}$ lymphocytes isolated from peripheral blood in COPD. $A \mathrm{~m}]$ Pbysiol Lung Cell Mol Pibsiol 2003, 285:L492-499

20. McCaffrey TA: TGF-betas and TGF-beta receptors in atherosclerosis. Cytokine Growth Factor Rev 2000, 11:103-114

21. Lutgens E, Gijbels M, Smook M, Heeringa P, Gotwals P, Koteliansky VE, Daemen MJ: Transforming growth factor-beta mediates balance between inflammation and fibrosis during plaque progression. Arterioscler Thromb V asc Biol 2002, 22:975-982

22. Gojova A, Brun V, Esposito B, Cottrez F, Gourdy P, Ardouin P, Tedgui A, Mallat Z, Groux H: Specific abrogation of transforming growth factor-beta signaling in T cells alters atherosclerotic lesion size and composition in mice. Blood 2003, 102:4052-4058

23. Parkinson $\mathrm{K}$, Balmain $\mathrm{A}$ : Chalones revisited-a possible role for transforming growth factor beta in tumour promotion. Caringenesis 1990, 11:195-198

24. Sherman JH, Baxter CS, Albert RE: Stimulation of TGF-beta $1 \mathrm{mRNA}$ concentration in mouse skin treated with benzo[a]pyrenc. Carinogenesis 1992, 13:83-86

25. Abdel-Razzak Z, Corcos L, Fautrel A, Campion JP, Guillouzo A: Transforming growth factor-beta 1 down-regulates basal and polycyclic aromatic hydrocarbon-induced cytochromes P-450 $1 \mathrm{~A} 1$ and $1 \mathrm{~A} 2$ in adult human hepatocytes in primary culture. Mo! Pharmaco/ 1994, 46:1100-1110

26. Lutgens E, Daemen M]: Transforming growth factor-beta: a local or systemic mediator of plaque stability? Cir Res 2001, 89:853-855 

Chapter 7

General Discussion 


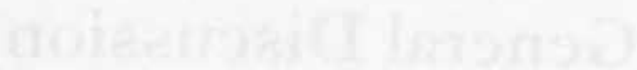




\section{Main findings of this thesis}

In the present thesis we investigated the effect of oral $\mathrm{PAH}$ exposure on the development of atherosclerosis in apoE-KO mice. Our hypothesis was that the PAH-induced DNA damage would be the main mechanism of action in the induction of atherogenesis by this genotoxic chemical. The main findings of the studies presented in this thesis show that:

1. The aorta is indeed a target organ for the formation of B[a]P-derived DNA adducts;

2. Dietary modulated plasma lipid levels do not have a profound effect on the formation of these DNA adducts in several potential target tissues of both the apoE*3-Leiden mice and the apoE-KO mice;

3. Acute exposure to $\mathrm{B}[\mathrm{a}] \mathrm{P}$ results in enhanced levels of BPDE-DNA adducts in the aorta of apoE-KO mice, but also in increased aortic levels of the stable lipid peroxidation DNA adduct $1, N^{6}$-ethenodeoxyadenosine $(\boldsymbol{\varepsilon d A})$. The formation of these etheno-DNA adducts was positively correlated to the plasma levels of HDL;

4. Chronic exposure to B[a]P results in an increased atherosclerotic plaque progression chatacterized by an inflammatory phenotype in apoE-KO mice;

5. $\mathrm{B}[\mathrm{e}] \mathrm{P}$, the non-DNA adduct forming structural isomer of $\mathrm{B}[\mathrm{a}] \mathrm{P}$ was similar potent as $\mathrm{B}[\mathrm{a}] \mathrm{P}$ in inducing a more inflammatory plaque phenotype in apoE$\mathrm{KO}$ mice;

6. $\mathrm{B}[\mathrm{a}] \mathrm{P}$ exposure results acutely in upregulation of TGF $\beta 1$ gene expression in the aorta of apoE-KO mice, and chronically in an increased plaque macrophage protein expression.

\section{Chemical atherogenesis: the response-to-injury hypothesis and the monoclonal theory}

Based on the ideas of Virchows' inflammatory theory of 1856 , the group of $\bar{R}$. Ross formulated the response-to-injury hypothesis in 1973.' This theory states that atherosclerosis begins as a compensatory reaction of the artery wall to a certain injury (chapter 1). In the same year Benditt and Benditt laid the foundation for the monoclonal theory with the publication of their paper: "Evidence for a monoclonal origin of human atherosclerotic plaques". 2 They challenged the response-to-injury idea of wound healing by the observation that human atherosclerotic plaques exhibit a monoclonal phenotype, thereby suggesting that it might be a benign tumor of the vessel wall (chapter 1). This latter suggestion 
opened the road for the investigation of the effects of vessel wall damaging agents like (carcinogenic) chemicals or viruses in relation to atherosclerosis. ${ }^{3}$

The field of chemical atherogenesis investigated the role of chemicals, preferably carcinogenic chemicals like PAHs, as the vessel wall damaging agents causing the onset of atherosclerotic plaque development. ${ }^{4-8}$ However, mainly all studies used the ideas of the monoclonal theory as their starting point. This concentrated the interest in features as observed in chemical carcinogenesis like DNA damage and (uncontrolled) proliferation, ${ }^{9}$ in a model of initiation, promotion and progression (Figure 7.1).

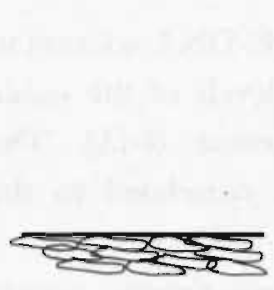

normal

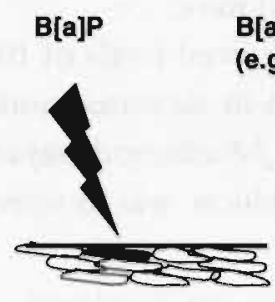

initiation

$B[a] P$ or other promoting agent

(e.g. TPA, methoxamine)

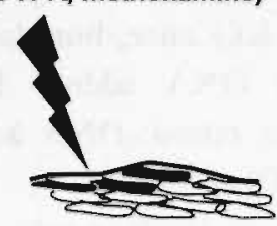

promotion

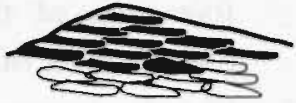

progression

_ Endothelial cell lineage

$\infty$ Smooth muscle cell

Transformed smooth muscle cell

Figure 7.1 The originally proposed model for chemical atherogenesis, based on initiation-promotion-progression mechanism obtained from chemical carcinogenesis.

\section{PAHs and the original initiation-promotion-progression idea of atherogenesis}

Based on the knowledge obtained from studies on chemical carcinogenesis, it was believed that chemical-induced atherogenesis could develop like a benign smooth muscle cell tumor. Exposure to a DNA damaging agent like B[a]P thereby induces arterial DNA damage. This would lead to mutation(s) in single smooth muscle cells, ${ }^{10-12}$ which in turn could disturb normal cell cycle resulting in uncontrolled proliferation. By this uncontrolled proliferation an atherosclerotic plaque would develop, like a sort of benign tumor, causing luminal narrowing. ${ }^{13}$ The most important studies on PAH-mediated atherogenesis focused on the induction and 
progression of atherosclerotic plaques using experimental animals. ${ }^{46,14}$ Whereas all studies were able to show an enhanced plaque progression after PAH exposure, and some even showed an increase in proliferation and transforming capacity in NIH3T3 cells by plaque derived DNA, ${ }^{15}$ there was no agreement on whether mutational events were involved in the induction of atherosclerosis., ${ }^{416}$ This disagreement on plaque induction becomes most obvious by the studies of Bond $e t$ al. (1981) and Majesky et al. (1985). In both studies an actual initiation-promotion protocol is used in SC-strain chickens to elicit atherosclerotic plaque development. Whereas the group of Bond failed to obtain enhancement of lesion formation, ${ }^{5}$ Majesky and coworkers found focal proliferation of smooth muscle cells by an initiation-promotion sequence. ${ }^{17}$

One explanation for the inconclusiveness on actual induction of plaques in the different studies might be the differences in the used dosage and dosing regiment of the PAHs. ${ }^{6}$ Furthermore, the animal type and strain seem to play an important role. ${ }^{18}$ As we described in chapters 4 and 5 , long-term oral exposure to $5 \mathrm{mg} / \mathrm{kg}$ bw $\mathrm{B}[\mathrm{a}] \mathrm{P}$ results in enhanced progression of existing plaques, but not in an increase of the number of plaques. ${ }^{19}$ These results are in agreement with the findings of Gairola t al. (2001), ${ }^{20}$ which also showed an increase in plaque size, but not in plaque number in apoE-KO mice daily exposed to sidestream cigarette smoke for 7,10 and 14 weeks.

In line with the idea that PAHs have a similar mechanism of action in the development of cancer and atherosclerosis, ${ }^{21}$ it can be hypothesized that the carcinogenic potency of PAHs would correlate with their atherogenicity. Indeed the strong carcinogenic PAH 7,12-dimethylbenz[a]anthracene (DMBA) proved more potent than the carcinogen $\mathrm{B}[\mathrm{a}] \mathrm{P}$ to elicit atherosclerotic lesions in several animal studies. ${ }^{45.14}$ However, results were inconsistent with regard to the atherogenic properties of the non-carcinogenic PAH B[ejP. Whereas Revis ef al. (1984) showed that $B[e] P$ had no effect on atherosclerotic plaque development in pigeons, ${ }^{14}$ Penn et al. (1988) found that B[e]P modulated atherosclerotic plaque formation, however to a lesser extent than B[a]P. ${ }^{8}$ In chapter 5 of this thesis we describe that $\mathrm{B}[\mathrm{e}] \mathrm{P}$ is just as potent as $\mathrm{B}[\mathrm{a}] \mathrm{P}$ to modulate the atherosclerotic plaque phenotype in apoE-KO mice, thereby suggesting that the carcinogenic porency of PAHs can at least not completely predict their atherogenic capacity.

More recent studies have focused on a critical event in tumor formation: the induction of DNA damage. ${ }^{22-25}$ We showed in the chapters 2,3 and 4 of this thesis that the aorta is a target organ for $\mathrm{B}[\mathrm{a}] \mathrm{P}$-induced $\mathrm{DNA}$ damage in apoE- $\mathrm{KO}$ mice. ${ }^{26-28}$ Bulky DNA adducts were also previously found in the aorta of smoke exposed rats ${ }^{23,29}$ The presence of bulky DNA adducts was also found in human arterial tissues. These adduct levels correlated to the severity of the atherosclerotic 
disease, but also to known risk factors like cigarette smoking. ${ }^{22,25,30-32}$ Moreover, not only direct DNA damage but also levels of lipid peroxidation mediated DNA damage ( $\varepsilon \mathrm{dA}$ adducts) were increased in the aorta of apoE-KO mice after acute B[a]P exposure (chapter 3).27 Cholesterol fed rabbits also exhibited increased plaque levels of 8 -oxodG, another marker for oxidative DNA damage. ${ }^{33}$ In the apoE-KO mice chronically exposed to $\mathrm{B}[\mathrm{a}] \mathrm{P}$ or $\mathrm{B}[\mathrm{e}] \mathrm{P}$ we did not observe an extra induction of 8-oxodG levels in the plaques (chapter 5), this might be explained by the fact that the apoE-KO mouse is a hyperlipidemic model in which basal plasma cholesterol levels are already high in general..$^{34}$ Moreover, as shown by several other PAH-exposure studies in animals, ${ }^{4,5,20}$ we observed no differences in plasma lipid levels due to chronic $\mathrm{B}[\mathrm{a}] \mathrm{P}$ or $\mathrm{B}[\mathrm{e}] \mathrm{P}$ exposure in these apoE- $\mathrm{KO}$ mice (chapter 4 and 5). Thus, increased plasma cholesterol levels, proven to be an atherogenic risk factor that can act synergistically with cigarette smoke, ${ }^{35-37}$ cannot account for the underlying mechanism of PAH-mediated atherogenesis.

In conclusion, the published data on a PAH-induced atherogenic mechanism do not fully support the idea of initiation-promotion-progression and show many inconsistencies. Therefore, we believe that the mechanism by which PAHs such as $\mathrm{B}[\mathrm{a}] \mathrm{P}$ modulate atherosclerosis cannot simply be explained by the ideas of chemical-based carcinogenesis. It is true that $\mathrm{B}[\mathrm{a}] \mathrm{P}$ induces profound arterial DNA damage, but our results favor effects on plaque progression rather than initiation. Moreover, a non-DNA damaging $\mathrm{PAH}$ as $\mathrm{B}[\mathrm{e}] \mathrm{P}$ proved to be just as potent as $\mathrm{B}[\mathrm{a}] \mathrm{P}$ to modulate atherosclerotic plaque progression (chapter 5), suggesting that pathways not related to DNA damage may be involved as well.

\section{Chemical atherogenesis: a revision of the pathogenesis}

It is incontrovertibly proven that PAHs modulate the process of atherogenesis. ${ }^{38,39}$ The main effect of PAHs in our studies was a more inflammatory plaque phenotype, characterized by a marked increase in the number of T-lymphocytes in the plaques of $\mathrm{B}[\mathrm{a}] \mathrm{P}$-, and $\mathrm{B}[\mathrm{e}] \mathrm{P}$-exposed animals (chapter 4 and 5), but no differences in the number of plaque smooth muscle cells. Furthermore, we did not observe an increase in plaque collagen content or apoptosis. Since there were no major abnormalities in the liver after $\mathrm{PAH}$-exposure, together with the fact that the levels of peripheral blood immunological cells were not changed upon PAH exposure, we concluded that the observed inflammatory response was local and plaque specific. Thus far, we are the first to report any differences in cellular composition of the plaques after oral PAH exposure. Previously published studies on the role of PAHs in atherogenesis mainly focused at the number and size of the 
plaques, sometimes extended with the proliferation rate and the transforming capacity of the plaque cells. One other study performed immunohistochemical staining for macrophages and T-lymphocytes in the plaques of apoE-KO mice but did not observe any significant changes in cellular plaque composition. However, these animals were exposed inhalatory to sidestream cigarette smoke, which is a complex mixture of PAHs and other chemicals. ${ }^{20}$

In an attempt to get more insight in the mechanism behind the PAH-induced recruitment of T-lymphocytes in the plaques, we focused on the role of inflammatory cytokines such as TGF $\beta 1$ (chapter 5 and 6 ). TGF $\beta$, a growth factor with dualistic features, was first recognized as an anti-inflammatory cytokine that plays a role in wound healing. ${ }^{40,41}$ It was proven to be involved in both cancer and atherosclerosis. ${ }^{42-44}$ We showed that chronic $\mathrm{B}[\mathrm{a}] \mathrm{P}$ and $\mathrm{B}[\mathrm{e}] \mathrm{P}$ exposure leads to an enhanced inflammatory plaque phenotype in apoE-KO mice, together with increased macrophage protein levels of TGF $\beta 1$ (chapter 5). It is known from PAH-induced skin cancer that both TGF $\beta 1 \mathrm{mRNA}$ and protein levels are upregulated. ${ }^{43,45}$ However, in atherogenesis it was proven that inhibition of TGF $\beta 1$ was associated with the acceleration of atherosclerosis and the induction of inflammatory plaque phenotypes. ${ }^{41,44}$ As upregulation of the Ah-receptor leads to suppression of TGF $\beta,{ }^{46}$ the observation that both the $\mathrm{Ah}$-receptor inducer $\mathrm{B}[\mathrm{a}] \mathrm{P}$, and, although to a lesser extent, the non Ah-receptor binding $\mathrm{B}[\mathrm{e}] \mathrm{P}$, lead to an increase of TGF $\beta$ in the plaques, suggests that other Ah-receptor independent pathways might be involved in chemical atherogenesis. ${ }^{47}$ Finally, gene expression data showed that acute exposure to $\mathrm{B}[\mathrm{a}] \mathrm{P}$ did not lead to an upregulation of the pro-inflammatory cytokines TNF $\alpha, \mathrm{MCP} 1$, and Il-6, but in an increase of the antiinflammatory TGF $\beta$ in the aorta of apoE-KO mice, suggesting that modulation of TGF $\beta$ is an early event in PAH-induced atherogenesis (chapter 6).

In conclusion, the results presented in this thesis show that the effect of PAHs on the progression of atherosclerosis is not merely explained by the DNA damaging effects of these compounds. Plasma lipid levels were not affected by the PAHexposure and there was no dysregulation of cell cycle phenomena such as apoptosis, proliferation and $\mathrm{p} 53$ that might have explained the enhanced plaque progression. However, chronic PAH-exposure in apoE-KO mice resulted in a local, plaque specific inflammatory reaction and an upregulation of TGF $\beta 1$. Based on these observations we propose the following mechanism: upon entering the body, PAHs can be metabolically activated and cause substantial DNA damage. Moreover, they progress atherosclerotic plaque development by causing local, plaque specific inflammation, which seems to be orchestrated by modulation of cytokines such as TGF $\beta$ (Figure 7.2). 


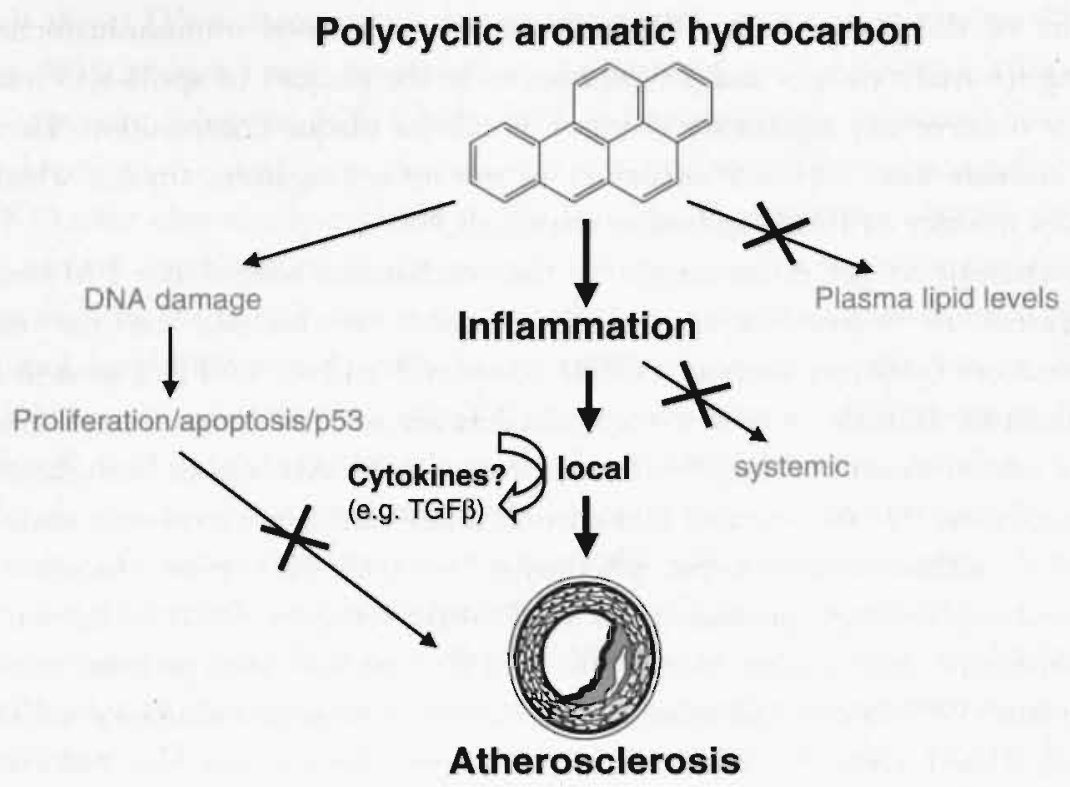

Figure 7.2. New proposed mechanism of PAH-modulated atherosclerotic plaque progression based on the results presented in this thesis.

\section{Limitations, future directions and concluding remarks}

The aim of the studies presented in this thesis was to get more insight in the mechanism of PAH-induced atherogenesis.

We chose to work with the severe atherosclerotic apoE-KO mice, which develop atherosclerosis spontaneously and rapidly from 10 weeks of age. ${ }^{48}$ However, this made the investigation into plaque initiation difficult. A more mild and controllable atherosclerotic mouse model like the LDL receptor knockout mouse would be more appropriate to specifically address questions regarding plaque initiation. However, in these mice atherosclerotic plaques will only develop upon feeding an atherogenic diet and even then, the first advanced atherosclerotic lesions won't develop until 8 months of age. ${ }^{49,50}$

We showed that arterial DNA damage could at least not fully account for the progression of atherosclerosis. To completely exclude the induction of DNA damage in chemical atherogenesis, studies in apoE- $\mathrm{KO}$ mice also deficient in nucleotide excision repair (e.g. XPA-/-/apoE-/-) or base excision repair (e.g. OGG1-/-/apoE-/-) should be performed. The XPA/apoE double knockout could be used to address the influence of bulky DNA adducts such as BPDE- 
DNA adducts on atherosclerotic plaque progression, whereas the latter can answer the role of small lesions like oxidative DNA damage.

Chronic PAH-exposure in apoE-KO mice induces a local inflammatory plaque phenotype characterized by an increase in $\mathrm{CD} 45$ and $\mathrm{CD} 3$ positive cells as well as an upregulation of TGF $\beta$ in plaque macrophages. The inflammatory phenotype should be further elucidated for example by looking at subsets of T-cells like the T-helper cells (CD4 positive) and the cytotoxic/suppressor T-cells (CD8 positive). Moreover, the role of T-cells in PAH-mediated atherogenesis can be further investigated by using an immunodeficient apoE-KO mouse, like the SCID $\mathrm{x}$ apoE/- mouse, which is deficient in both $\mathrm{T}$ and $\mathrm{B}$ cells.

To further dissect the TGF $\beta$ pathway in PAH-induced inflammatory atherogenesis, atherogenic mice in which TGF $\beta$ is disrupted, preferably in T-cells, should be used to study the effects of chronic PAH exposure on plaque formation. ${ }^{51}$ Another approach that could lead to more insight in the TGF $\beta$ pathway, but perhaps also reveal other cytokines involved in chemical atherogenesis, is the use of micro-arrays on aortic samples of acute and chronically $\mathrm{PAH}$-exposed apoE-KO mice.

All our studies and conclusions are based on data generated in atherosclerotic mice. At this stage, translation to the human situation is too preliminary and the data obtained here should be looked at as a mechanistic feature of chemical atherogenesis. However, the results provide a clear direction for further research into the inflammatory role of PAHs in the development of atherosclerosis. 


\section{References}

1. Ross R, Glomset JA: Atherosclerosis and the arterial smooth muscle cell: Proliferation of smooth muscle is a key event in the genesis of the lesions of atherosclerosis. Sizence 1973, 180:1332-1339

2. Benditt EP: Evidence for a monoclonal origin of human arherosclerotic plaques and some implications. Circulation 1974, 50:650-652

3. Penn A: Molecular alterations critical to the development of arteriosclerotic plaques: a role for environmental agents. Envimn Health Perspect 1989, 81:189-192

4. Albert RE, Vanderlaan M, Burns FJ, Nishizumi M: Effect of carcinogens on chicken atherosclerosis. Cancer Res 1977, 37:2232-2235

5. Bond JA, Gown AM, Yang HL, Benditt EP, Juchau MR: Further investigations of the capacity of polynuclear aromatic hydrocarbons to elicit atherosclerotic lesions. J Taxicol Emviron Health 1981, 7:327-335

6. Penn A, Batastini G, Soloman J, Burns F, Albert R: Dose-dependent size increases of aortic lesions following chronic exposure to 7,12-dimethylbenz(a)anthracene. Cancer Res $1981,41: 588-592$

7. Penn AL, Batastini GG, Albert RE: Age-dependent changes in prevalence, size and proliferation of arterial lesions in cockerels. II. Carcinogen-associated lesions. Artey 1981, Q:382-393

8. Penn A, Snyder C: Arteriosclerotic plaque development is 'promoted' by polynuclear aromaric hydrocarbons. Carainogenesis 1988, 9:2185-2189

9. Gelboin HV: Benzo[alpha|pyrene metabolism, activation and carcinogenesis: role and regulation of mixed-function oxidases and related enzymes. Pbysiol Rey 1980, 60:1107-1166

10. Pessah-Rasmussen H, Stavenow L, Xu CB, Berglund A: Increased smooth muscle cell proliferation by dimethylbenzanthracene is correlated to variations in activity of ornithine decarboxylase but not arylhydrocarbonhydroxylase. Artoy 1991, 18:240-255

11. Ramos KS, Bowes RC, 3rd, Ou X, Weber TJ: Responses of vascular smoorh muscle cells to toxic insult: cellular and molecular perspectives for environmental toxicants. I Toxicol Emvion Healtb 1994, 43:419-440

12. International Commission for Protection Against Environmental Mutagens and Carcinogens. The possible involvement of somatic mutations in the development of atherosclerotic plaques. Report of ICPEMC Subeomminte T/1. Conclusions and recommendations. Mutar Res 1990, 239:143-148

13. Schwarz SM, Murry CE: Proliferation and the monoclonal origins of arhercselerotic lesions. Anmu Ren Med 1998, 49:437-460

14. Revis NW, Bull $R$, Laurie D, Schiller $C A$ : The effectiveness of chemical carcinggens to induce atherosclerosis in the whife Carneau pigeon. Texirology 1984. 32:215-227

15. Penn A, Hubbard FC. Jr., Parkes JL: Transforming potential is detectable in arteriosclerotic plaques of young animals. Antrosche Thinmp 1991, 11:1053-1058

16. Batastini $G$, Penn $A$ : An ulirastructural comparison of carcinogen-associared and spontancous aortic lesions in the cockerel. Am J Patho/ 1984, 114:403 409

17. Mą̣esky MW, Reidy MA. Benditt EP. Juchau MRR: Focal smoorh muscle proliferation in the aortic intima produced by an initiation-promotion sequence. Proc Natl Acad Sit U S A $1085,82: 3450-3454$

18. Majesky MW. Yang HY, Benditr EP. Juchau MR: Carcinogenesis and atherogenesis: differences in monooxygenase inducibility and bioacrivation of benzo|a|pyrene in aortic and heparic tissues of atherosclerosis susceptible versus resistant pigcons. Carcingenesis $1983,4: 647-652$

19. Curfs DMJ, Lutgens E, Gijbels MJ, Kockx MM, Daemen MJAP, van Schooten F]: Chronic exposure to the carcinogenic compound benzo|a|pyrene induces larger and phenorypically different atherosclerotic plaques in apoE-knockout mice. Am J Pathol, in press 
20. Gairola CG, Drawdy MI, Block AE, Daugherty A: Sidestream cigarette smoke accelerates atherogenesis in apolipoprotein E-/-mice. Atherosclerosis 2001, 156:49-55

21. Ross JS, Stagliano NE, Donovan MJ, Breitbart RE, Ginsburg GS: Arherosclerosis and cancer: common molecular pathways of disease development and progression. Ann $N Y$ Acad Sci 2001, 947:271-292; discussion 292-273

Van Schooten FJ, Hirvonen A, Maas LM, De Mol BA, Kleinjans JC, Bell DA, Durrer JD: Putative susceptibility markers of coronary artery disease: association between VDR genotype, smoking, and aromatic DNA adduct levels in human right atrial tissue. Faseb J $1998,12: 1409-1417$

23. Izzoti A, Camoirano A, Cariglia C, Tampa E, De Flora S: Formation of DNA adducts in the aorta of smoke-exposed rats, and modulation by chemopreventive agents. Mutat Res 2001, 494:97-106

24. Izzotti A, D'Agostini F, Bagnasco M, Scatolini L, Rovida A, Balansky RM, Cesarone CF, De Flora S: Chemoprevention of carcinogen-DNA adducts and chronic degenerative diseases. Cancer Res 1994, 54:1994s-1998s

25. Binkova B, Strejc P, Boubelik O, Stavkova Z, Chvatalova I, Sram RJ: DNA adducts and human atherosclerotic lesions. Int J Hyg Environ Health 2001, 204:49-54

26. Curfs DMJ, Beckers L, Godschalk RWL, Gijbels MJ, van Schooren FJ: Modulation of plasma lipid levels affects benzo|a|pyrene-induced DNA damage in tissues of rwo hyperlipidemic mouse models. Environ Mol Mutagen 2003, 42:243-249

27. Godschalk R, Curfs DM], Bartsch H, van Schooten FJ, Nair J: Benzo[a]pyrene enhances lipid peroxidation induced DNA damage in aorta of apolipoprotein E knockout mice. Free Radic Res 2003, 37:1299-1305

28. Curfs DM, Lutgens E, Gijbels MJ, Kockx MM, Daemen MJ, Van Schooten FJ: Chronic Exposure to the Carcinogenic Compound Benzo[a]Pyrene Induces Larger and Phenotypically Different Atherosclerotic Plaques in ApoE-Knockout Mice. Am J Patbol 2004, 164:101-108

29. Izzori A, Balansky RM, Dagostini F, Bennicelli C, Myers SR, Grubbs CJ, Lubet RA, Kelloff GJ, De Flora S: Modulation of biomarkers by chemopreventive agents in smokeexposed rats. Cancer Res 2001, 61:2472-2479

30. Izzotti $A$, Cartiglia $C$, Lewtas J, De Flora S: Increased DNA alterations in atherosclerotic lesions of individuals lacking the GSTM1 genotype. Faseb J 2001, 15:752-757.

31. Izzotti A, De Flora S, Petrilli GL, Gallagher J, Rojas M, Alexandrov K, Bartsch H, Lewtas J: Cancer biomarkers in human atherosclerotic lesions: derection of DNA adduce. Cancer Epidemiol Biomarkers Pro 1995, 4:105-110

32. Binkova B, Smethorsky Z, Streje P, Boubelik O. Stavkova Z, Chvatalova I, Sram Rj: DNA-adducrs and atherosclerosis: a study of accidental and sudden death males in the Crech Republic. Mutat Res 2002, 501:115-128

33. Martinet W. Knaapen MW, De Meyer GR, Herman AG, Kockx MM: Oxidative DNA damage and repair in experimental atherosclerosis are eversed by dietary lipid lowering. Cin Res 2001, 88:733-739

34. Zhang SH, Reddick R., Piedrahita JA, Maeda N: Spontaneous hypercholesterolemia and atterial lesions in mice lacking apolipoprotein E. Saience 1992, 258:468-471

35. Glasser SP. Selwyn AP. Ganz P: Atherosclerosis: risk factors and the vascular endothelium. Am Heart ] 1996, 131:379-384

36. Castelli WP: Cardiovascular disease: parhogenesis, epidemiology, and risk among users of oral contraceptives who smoke. Am J Obstet Gynecol 1999, 180:\$349-356

37. Perkins KA: The synergistic effect of smoking and serum cholesterol on coronary heart disease. Health Pyychol 1985, 4:337-360

38. Hansen ES: International Commission for Protection Against Environmental Mutagens and Carcinogens. ICPEMC Working Paper $7 / 1 / 2$. Shared risk factors for cancer and atherosclerosis-a review of the epidemiological evidence. Mutat Res 1990, 239:163-179

39. Wakabayashi $\mathrm{K}$ : International Commission for Protection Against Environmental Mutagens and Carcinogens. ICPEMC Working Paper 7/1/3. Animal studies suggesting 
involvement of mutagen/carcinogen exposure in atherosclerosis. Mutat Res 1990, 239:181187

40. McCaffrey TA: TGF-betas and TGF-beta receptors in atherosclerosis. Cytokine Growtb Factor Rev 2000, 11:103-114

41. Mallat Z, Gojova A, Marchiol-Fournigault C, Esposito B, Kamate C, Merval R, Fradelizi D, Tedgui A: Inhibition of transforming growth factor-beta signaling accelerates atherosclerosis and induces an unstable plaque phenotype in mice. Cin Res 2001, 89:930934

42. Wieser R: The transforming growth factor-beta signaling pathway in tumorigenesis. Curr Opin Oncol 2001, 13:70-77

43. Sherman JH, Miller ML, Albert RE, Baxter CS: Dose- and time-dependent expression of transforming growth factor-beta $1 \mathrm{mRNA}$ and protein in mouse epidermis and papillomas after repeated topical application of benzo|a]pyrene. Mol Carcinog 1993, 8:264-271

44. Lutgens E, Gijbels M, Smook M, Heeringa P, Gotwals P, Koteliansky VE, Daemen M]: Transforming growth factor-beta mediates balance berween inflammation and fibrosis during plaque progression. Arterioscler Thromb V asc Biol 2002, 22:975-982

45. Sherman JH, Baxter CS, Albert RE: Stimulation of TGF-beta 1 mRNA concentration in mouse skin treated with benzo[a]pyrene. Carcinogenesis 1992, 13:83-86

46. Zaher H, Fernandez-Salguero PM, Letrerio J, Sheikh MS, Fornace AJ, Jr., Roberts AB, Gonzalez FJ: The involvement of aryl hydrocarbon receptor in the activation of transforming growth factor-beta and apoptosis. Mol Pbarmacol 1998, 54:313-321

47. Guo J, Sartor M, Karyala S, Medvedovic M, Kann S, Puga A, Ryan P, Tomlinson CR: Expression of genes in the TGF-beta signaling pathway is significantly deregulated in smooth muscle cells from aorta of aryl hydrocarbon receptor knockout mice. Toxicol Appl Pharmacol 2004, 194:79-89

48. Nakashima Y, Plump AS, Raines EW, Breslow JL, Ross R: ApoE-deficient mice develop lesions of all phases of atherosclerosis throughout the arterial tree. Arterioscler Thromb 1994, 14:133-140

49. Rajavashisth T, Qiao JH, Tripathi S, Triparhi J, Mishra N, Hua M, Wang XP, Loussararian A. Clinton S, Libby P. Lusis A: Heterozygous osteopetrotic (op) mutation reduces atherosclerosis in LDL receptor-deficient mice. J Clin Invest 1998, 101:2702-2710

50. Sukhova GK, Zhang Y, Pan JH, Wada Y, Yamamoro T, Naito M, Kodama T, Tsimikas S, Witzrum JL, Lu ML, Sakara Y, Chin MT, Libby P, Shi GP: Deficiency of carhepsin S reduces atherusclerosis in L.DL. receptor deficient mice. I Clin Jmest 2003, 111:897-906

51. Roberson AK, Rudling M. Zhou X, Gorelik L, Flavell RA, Hansson GK: Disruption of TGF-beta signaling in T ectls accelerates atherosclerosis. J Can Invest 2003. 112:1342-1350 



\section{Summary / Samenvatting}




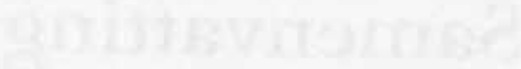




\section{Summary}

Polycyclic aromatic hydrocarbons, products of the incomplete combustion of organic materials, are a large group of lipophilic environmental chemicals to which the general population is exposed on a daily basis. The most prominent ways of exposure are via contaminated food, occupational exposure, air pollution and cigarette smoking. PAHs, basically inert, can be activated into reactive metabolites by the cytochrome P450 enzyme system upon entering the body. It is proven that PAHs play a role in the development of chronic degenerative diseases like cancer and cardiovascular diseases such as atherosclerosis. Whereas in the development of cancer, the tumor initiating and promoting events of PAHs are ascribed to their DNA damaging properties, the underlying mechanism of PAH-mediated atherogenesis is mainly unknown.

In the present thesis we investigated whether and how PAHs are involved in the development of atherosclerosis in apoE-KO mice. We hypothesized that PAHs modulate atherosclerotic plaque development by DNA damaging events in the arterial vessel wall. The first part of the thesis focuses on the DNA damaging effects of B[a]P in the arterial vessel wall. Subsequently, we characterized the effects of chronic $\mathrm{B}[\mathrm{a}] \mathrm{P}$ exposure on atherosclerotic plaque development in the atherosclerotic apoE-KO mouse. The results of these studies showed that, regardless of the DNA damaging events in the arterial vessel wall, PAHs progress the atherosclerotic plaque development towards a more inflammatory phenotype. Based on these results, the last part of the thesis focuses on the mechanisms involved in this local, plaque specific inflammatory effect of PAHs and the role of some inflammatory cytokines such as TGF $\beta$ in this process.

In chapters 2 and 3 we characterized the direct and indirect arterial DNA damaging effects of acure B[a]P exposure. In chapter 2 we showed that the aorta is a target organ for the direct DNA damaging effects of B[a]P (BPDE-DNA adducts) as well as the fact that dietary modulation of plasma lipid levels did not significantly influence the DNA adduct formation in both the apoE-KO and the apoE*3-Leiden mouse, two atherosclerotic mouse models. Furthermore, we showed that the levels of BPDE-DNA adducts were higher in the apoE-KO mouse compared with the apoE*3-Leiden mouse.

Chapter 3 describes the formation of lipid perosidation derived exocyclic etheno-base adducts in the aorta of apoE-KO mice after acute exposure to B[a]P. Etheno-DNA adducts are a marker for oxidative DNA damage and we show that $B[a] P$ enhances the formation of $\varepsilon d A$ in the aorta of apoE-KO mice. 
After establishing that the aorta is indeed a target organ for $\mathrm{B}[\mathrm{a}] \mathrm{P}$-derived DNA damage, we investigated in chapter 4 the effects of chronic $\mathrm{B}[\mathrm{a}] \mathrm{P}$ exposure on atherosclerotic plaque formation in apoE-KO mice. We showed an enhanced atherosclerotic plaque progression without an extra induction of new plaques. Furthermore, we describe an inflammatory change in the plaque phenotype characterized by increased numbers of plaque macrophages and T-lymphocytes, without a clear effect on collagen content, apoptosis, proliferation or $\mathrm{p} 53$ protein expression in the plaques. Moreover, no differences in the number of plaque smooth muscle cells are observed and plasma lipid levels are not modulated by the $\mathrm{B}[\mathrm{a}] \mathrm{P}$ exposure.

In chapter 5 we tested our main hyporhesis that PAHs influence the development of atherosclerosis by DNA adducting events in the aorta based on the observation that $\mathrm{B}[\mathrm{e}] \mathrm{P}$, the non-DNA adduct forming structural isomer of $\mathrm{B}[\mathrm{a}] \mathrm{P}$, elicits the same inflammatory atherosclerotic phenotype as $\mathrm{B}[\mathrm{a}] \mathrm{P}$. Moreover we extend our knowledge on PAH-mediated atherogenesis by the observation that the levels of peripheral immunological blood cells are not changed upon PAH exposure, thereby concluding that it is a local plaque specific inflammatory reaction. With regard to the plaque phenotype we show that TGF $\beta 1$ protein expression is increased in plaque macrophages and that there is no extra induction of oxidative DNA damage in plaque cells after chronic PAH exposure.

Chapter 6 describes the acute effect of B[a]P exposure on the gene expression of several inflammatory cytokines in the arterial vessel wall. We show an up-regulation of the anti-inflammatory cytokine TGF $\beta$ in the aorta of apoE$\mathrm{KO}$ mice after acute $\mathrm{B}[\mathrm{a}] \mathrm{P}$ exposure, thereby suggesting that TGF $\beta$ plays a role early in the process of PAH-mediated arherogenesis. Furthermore, we show that the acure exposure to $\mathrm{B}[\mathrm{a}] \mathrm{P}$ did not result in modulation of the pro-inflammatory cytokines TNF $\alpha$, MCPI and Il-6.

In chapter 7 the findings of this thesis are discussed. The first part of chapter 7 describes the ariginal ideas of DNA damage and the initiationpromotion-progression idea of chemical atherogenesis. Then, based on the findings obtained in this thesis we propose a revision of these ideas towards a more local inflammatory effect of PAHs in chemical atherogenesis. The chapter is concluded by the limitations of the studies performed in this thesis and some ideas for funure directions.

In conclusion, DNA binding events in the arterial wall are not the main mechanism by which PAHs modulate atheroscleroric plaque development. Although the exact mechanism can still not be fully elucidated, we have shown that it is most likely a local inflammatory reacrion in which upregulation of TGF $\beta$ seems to be involved. 


\section{Samenvatting}

Polycyclisch aromatische koolwaterstoffen (PAKs) vormen een grote groep lipofiele chemische verbindingen die veelvuldig voorkomen in de voeding en het milieu en waaraan de algemene bevolking dagelijks wordt blootgesteld. PAKs worden gevormd tijdens de onvolledige verbranding van organische materialen en zijn over het algemeen onschadelijk. Echter, eenmaal in het lichaam kunnen PAKs worden omgezet in reactieve metabolieten met behulp van het cytochroom P450 enzym systeem. Het is aangetoond dat PAKs een rol spelen in het ontstaan van chronisch degeneratieve ziekten zoals kanker en hart-, en vaatziekten in het bijzonder aderverkalking (atherosclerose). In de pathogenese van kanker worden de initiërende en promotende werking van PAKs toegeschreven aan het feit dat ze het DNA kunnen beschadigen. Echter, over de rol van PAKs in de pathogenese van aderverkalking is nog weinig bekend.

In dit proefschrift is onderzocht of, en zo ja, hoe PAKs betrokken zijn bij het ontstaan en de ontwikkeling van aderverkalking in atherosclerose gevoelige apolipoproteine E knockout (apoE-KO) muizen. Onze oorspronkelijke hypothese was dat PAKs de ontwikkeling van atherosclerotische plaques moduleren via beschadigingen van het DNA in de arteriële vaatwand. Het eerste deel van dit proefschrift richt zich op de DNA beschadigende effecten van een sterk kankerverwekkende PAK, benzo[a]pyrene (B[a]P), in de arterïle vaatwand. Vervolgens zijn de effecten van chronische $\mathrm{B}[\mathrm{a}] \mathrm{P}$ blootstelling op de ontwikkeling van atherosclerotische plaques in de apoE-KO muis beschreven. De resultaten van deze studies laten zien dat PAKs, in verhouding tot andere organen, een verhoogde mate van arteriële DNA schade veroorzaken. In de progressie van atherosclerose echter, blijken PAKs een plaque fenotype te induceren dat zich vooral kenmerkt door verhoogde aantallen ontstekingscellen. Gebaseerd op deze resultaten, richt het laatste deel van dit proefschrift zich op dit lokale, plaque specifieke ontstekingseffect van PAKs. Hierbij wordt ondermeer gekeken naar de expressie van verschillende cytokines, waarvan bekend is dat ze betrokken zijn in ontstekingsprocessen, zoals bijroorbeeld TGF $\beta$.

In de hoofdstukken 2 en 3 worden de directe en indirecte DNA beschadigende effecten in de aorta beschreven na acute blootstelling aan B[a]P. In hoofdstuk 2 tonen we aan dat de aorta een doelwitorgaan is voor de directe DNA schade door $\mathrm{B}[\mathrm{a}] \mathrm{P}$; de niveaus van de interactieprodukten met het DNA (de zogenaamde BPDE-DNA adducten) zijn hoger dan die in andere organen. Ook laten we zien. dat modulatie van plasma cholesterol niveaus door middel van dieet geen significante invloed heeft op de vorming van deze DNA adducten. Bovendien 
tonen we aan dat de BPDE-DNA adduct niveaus hoger zijn in de extreem hyperlipidemische apoE-KO muis ten opzichte van de milde hyperlipidemische apoE*3-Leiden muis.

Hoofdstuk 3 beschrijft vervolgens de vorming van de lipid peroxidatie afgeleide etheno-adducten in de aorta van apoE-KO muizen na acute blootstelling aan B[a]P. Etheno-adducten zijn een marker voor oxidatieve DNA schade en we laten zien dat $\mathrm{B}[\mathrm{a}] \mathrm{P}$ de vorming van $\varepsilon \mathrm{dA}$ in de aorta van apoE-KO muizen verhoogt.

Nadat we hebben aangetoond dat de aorta inderdaad een doelwitorgaan is voor B[a]P geinduceerde DNA schade, gaan we in hoofdstuk 4 in op de effecten van chronische blootstelling aan $\mathrm{B}[\mathrm{a}] \mathrm{P}$ op de vorming van atherosclerotische plaques in apoE-KO muizen. We tonen aan dat er een versnelde ontwikkeling van atherosclerotische plaques is, maar ook dat er geen extra inductie van nieuwe plaques plaatsvindt. Verder beschrijven we ontstekings-gemedieerde veranderingen in het plaque fenotype die zich karakteriseren door toegenomen aantallen macrofagen en T-cellen in de plaques. Er is geen duidelijk effect op de hoeveelheid collageen in de plaques. Ook de mate van celdood (apoptose), proliferatie en de expressie van het 553 eiwit in de plaques is niet veranderd. B [a]P blootstelling heeft geen invloed op het aandeel gladde spiercellen in de plaques en ook de plasma cholesterol niveaus zijn niet veranderd.

In hoofdstuk 5 verwerpen we uiteindelijk onze oorspronkelijke hypothese dat de rol van PAKs in de ontwikkeling van arherosclerose volledig toegeschreven kan worden aan hun DNA bindende effecten in de vaatwand. We laten zien dat $\mathrm{B}[\mathrm{e}] \mathrm{P}$, een niet-DNA bindende isomeer van B[a]P, net zo goed in staat is een atherosclerotisch plaque fenotype te induceren dat zich kenmetkt door ontsteking. Hierdoor breiden we onze kennis op het gebied van PAK-gemedieerde arherogenese uit. We tonen aan dat de niveaus van perifeer immunologische bloedcellen niet veranderen door de PAK blootstelling en concluderen hieruit dat de ontstekingsreactie hoogstwaarschijnlijk lokaal en plaque specifiek is. Met betrekking tot het playue fenotype laten we zien dat chronische blootstelling aan PAKs leidt tot een verhoogde expressic van het TGF $\beta 1$ eiwit in de plaque macrofagen en dat er immunohistochemisch geen extra inductie van oxidatieve schade in de plaque cellen aantoonbaar is.

Hoofdstuk 6 beschrijft het acute effect van B[a]P blootstelling op de genexpressie van verschillende ontstekingsgemedieerde cytokines in de arteriële vaatwand. We laten zien dat het ontstekingsremmende cytokine TGF $\beta$ verhoogd tot expressie komt in de aorta van apoE-KO muizen na acute blootstelling aan $B[a] P$. Dit suggereert dat TGF vroeg in het proces van PAK-gemedieerde atherogenese een rol speelt. Verder laten we zien dat de B[a]P blootstelling niet 
leidt tot een modulatie van de ontstekingsstimulerende cytokines TNFo, MCP1 en Il-6.

In hoofdstuk 7 worden tenslotte de bevindingen van dit proefschrift bediscussieerd. Het eerste gedeelte van hoofdstuk 7 beschrijft de oorspronkelijke ideeën over DNA schade en het initiatie-promotie-progressie mechanisme in de chemische atherogenese. Vervolgens poneren we, op basis van de bevindingen van dit proefschrift, een herziene versie van deze ideeën, waarin de rol van PAKs in de chemische atherogenese wordt toegeschreven aan een lokaal ontstekingsgericht effect. Het hoofdstuk wordt afgesloten met een beschrijving van de beperkingen van de studies in dit proefschrift alsmede enkele suggesties voor verder onderzoek.

Concluderend kunnen we zeggen dat DNA bindende gebeurtenissen in de arteriële vaatwand niet het belangrijkste mechanisme vormen waardoor PAKs het proces van atherosclerotische plaque ontwikkeling beïnvloeden. Hoewel de studies in dit proefschrift het precieze mechanisme niet hebben kunnen achterhalen, hebben we laten zien dat het hoogstwaarschijnlijk om een lokale ontstekingsreactie gaat, waarbij in ieder geval een inductie van TGF $\beta$ betrokken lijkt te zijn. 



\section{Dankwoord}

En opeens was het zover, proefschrift af, tijd om te promoveren. Hoezo time flies when you're having fun?! De hulp en het enthousiasme die ik gedurende mijn aioperiode van iedereen gekregen heb, hebben me vaak angenaam verrast en ik wil dan ook een ieder die op de een of andere manier bijgedragen heeft aan de totstandkoming van dit boekje hartelijk bedanken!

Als eerste natuurlijk mijn dank aan mijn twee promotores prof. dr. F.J. van Schooten en prof. dr. M.J.A.P. Daemen. Beste Frederik-Jan, we kennen elkaar al een hele tijd, aangezien ik ook al stage bij jou gelopen had, als een soort voorbode op dit aio-project. Ik weet nog goed dat je enigszins twijfelde of je wel 4 jaar met me samen kon werken, aangezien ik soms toch net iets te fel kon zijn. Toch durfde je de uitdaging aan en vertrouwde je me jouw gedachtenkindje toe en liet je me vrij in de invulling en uitwerking van dit project. Ik kan natuurlijk alleen voor mezelf spreken, maar denk toch dat we een goed team vormden. Waar ik zo af en toe nog steeds iets te fel of drammerig was, behield jij je rust en zorgde ervoor dat ik niet te ver ging. Nou, dit is het resultaat, ik hoop dat jij net zo trots bent als ik dat dit jouw eerste promotie als promotor is!

Mat, bij het zoeken naar expertise op het gebied van atherosclerose en het werken met muizen kwamen we al snel bij jou terecht. Jij nam me op in jouw groep en zorgde voor de soms broodnodige structuur in mijn onderzoek. Een van de eerste dingen die ik van jou te horen kreeg was dat ik wat assertiever moest worden??!!. Geloof dat dat snel geregeld was. Jouw opmerking "Daniële, je mag altijd bij me binnen komen lopen ook als ik ogenschijnlijk gewichtig zit te doen" is kenmerkend voor onze samenwerking. Je was altijd enthousiast en makke altijd tijd voor me vrij! Zonder jouw steun en hulp was dit boekje er waarschijnlijk niet gekomen en het is dan ook niet zonder trots dat ik jou als mijn tweede promotor mag en wil bedanken!!

Vervolgens wil ik natuurlijk de GRAT-familie hartelijk bedanken voor de leuke en gezellige tijd. Simone, samen gestudeerd, de eerste stappen in de richting van een wetenschappelijke carrière door "ons" nirraat-diabetes onderzoek, samen aio en zelfs even kamergenootjes. You're next! Go for it! Edwin, bedankt voor alle gezellige en soms hilarische (muizen die ontsnappen richting labtafel en labjas, de GC-couveuse etc.) mouse-dates, onvergetelijk!! En dan Daniëlle P., zonder jouw hulp was mijn onderzoek nooit op tijd afgekomen. Je toewijding tijdens de ontelbare immuno's, quantimet- en microscopie uren, die jou soms tot wanhoop dreven, was fantastisch. D\&D: een perfect ream!! Verder Marcel, Lou en Pascal voor alle postlabel, muizen en computer dingetjes. Enne, Marcel, never panic, zelfs niet als een stikstofvat in je handen ontploft tijdens de RNA isolatie. Roger, eerst 
vanuit Heidelberg, later weer terug als GRAT-collega, thanx voor alle interesse en onze succesvolle samenwerking die geleid heeft tot hoofdstuk 3 van dit proefschrift. MC, dank je wel voor alle regeldingerjes, ik kon alrijd bij je terecht! Als de I-Mac weer eens crashte was daar Jan D. enne, nog dank je wel voor het achterhalen van de fout in de structuurformules van hoofdstuk 1! Patries, geen kamergenootjes want jij zit verdorie nog steeds in Leiden. Thanx voor de leuke tijd, met name tijdens het organiseren van de aio/oio dagen. Succes met je onderzoek! Ad, nog niet zo heel lang bij GRAT, maar vanaf het moment dat je begon vaak onmisbaar voor mij. Dank je wel voor alle gesprekken, het lezen van mijn manuscripten en het opbeuren als ik het even niet meer zag. Ben blij dat jij het athero onderzoek binnen GRAT voortzet en verheug me nu al op onze verdere samenwerking!

Mijn stagiaires Linda, Frank en Evi. Lin, jij moest het spits afbijten als stagiaire. Ik was zelf nog niet zo lang aio en ik denk dat het soms toch wel zwaar was om mijn tempo, gedachtengang en werkwijze te volgen. Toch hebben we een superleuke tijd samen gehad en ik heb er een lieve vriendin aan overgehouden. Hoofdstuk 2 is van en voor jou! Frank en Evi, stagiaires 2 en 3, jullie onderzoek was wat moeilijker en risicovoller. Helaas hebben teveel tegenslagen ertoe geleid dat we niet genoeg data hadden om ook hier een artikel uit te halen. Toch wil ik jullie bedanken voor de toewijding tijdens jullie stage. Evi, succes met je vervolg carrière! En Frank, ik vind het bijzonder leuk dat we nu weer collega's zijn en ik dingetjes van jou kan leren.

Pauline \& Remko, oud-collega's, dank jullie wel voor alle interesse en de ontspannende (P) Catan-avondjes. Harma, jij hebt GRAT al enige tijd verlaten. Moet zeggen, heb onze "einde-van-de-dag" gesprekken toch wel zo af en toe gemist. Gelukkig kunnen we nog regelmatig bijkletsen tijdens een etentje.

Tja, en dan natuurlijk de pathologie groep, mijn tweede thuisbasis. Iedereen bedankt voot de hartelijkheid warmee ik altijd bij jullie mocht en kon werken. Esther, jij werd opgezadeld met deze onwetende, vragende en eigenwijze dame. Jouw hulp en kennis van zaken was de basis voor mijn aio-project. Hoofdstuk 4 was er zeker niet gekomen zonder jou, dank je well! Anique, jij kreeg de opdracht van Mat me wegwijs te maken binnen het patho-lab. Je liep over van het werk, maar makte zonder meer tijd vrij om me rond te leiden, te leren hoe ik weefsel moest inbedden, coupes snijden en immuno's moest uirvoeren. Duizend maal dank daarvoor! Ine en Coby, dank jullie wel voor alle kleuringen die jullie voor mij hebben uitgevoerd. Kitty, de array-studie werd buiten onze schuld om een fiasco, toch hebben we pretrig samengewerkt en leuke gesprekken gevoerd. Ook al heb ik een postdoc plaats bij jou laten schieten, hoop dat we elkaar in de toekomst nog vaak regenkomen. Tenslotte natuurlijk het kippenhok: Marjo, Linda, 
Natasja, Judith, Kitty en Suzanne. Ik kwam nooit tevergeefs als ik even wilde buurten of weer eens iets nodig had. Ook de stap-avondjes waren onvergetelijk.

Jos, humane biologie was mijn adres voor de cholesterol bepalingen. Dank je wel voor het doormeten van al mijn plasma samples, geloof dat ik mijn laatste "friet met frikandel" schuld daarvoor nog steeds moet afbetalen.

Immunologie: Marjan, dank je wel voor alle hulp bij het FACSen en natuurlijk de gezellige tijd in Chicago. Enne, die ene muis die je hebt laten stikken tijdens het staartbloeden is je vergeven!! Peter, ik kon altijd even langskomen als ik weer eens een vraag had over een nieuwe proefopzet, antilichamen, probes e.d. Dank je wel nog voor het aanleveren van de CD68 probe!

Moleculaire Genetica, mijn nieuwe thuis bij een al bekende groep. Marion, half werkzaam bij genetica, half bij pathologie, legde jij voor mij de link naar de generica. Dank je wel voor het bekijken van alle levercoupes, de gezellige gesprekken tijdens het bekijken van plaques en het maken van foto's. Menno, proefopzetten bedenken, macrofagen aanleveren, meekijken naar resultaten, je had het druk, maar toch altijd een luisterend oor. In het bijzonder dank je wel dat je me een baan aanbood als postdoc, denk dat we een hele leuke en vruchtbare samenwerking tegemoet gaan. Monique, zonder jouw hulp en uitleg had ik nooit in zo'n kort tijdsbestek alle taqman metingen kunnen uitvoeren, thanx! Matthijs, ook al staan de data niet in dit proefschrift, wil je toch bedanken voor de tijd die je hebt vrijgemaakt om Evi, Ad en mij uitleg te geven en te helpen bij het isoleren en meten van L.DL.

Dr. Mark Kockx, dank je wel dat je bereid was om mijn TUNEL kleuringen uit te voeren in jouw lab.

BIGCAT, Chris en Rachel, dank jullie wel voor alle tijd die jullie gestoken hebben in het array fassco. Zonder jullie iuput stond of nu misschien wel een hoofdstuk in dit bockje gebaseerd op leugens.

En dan natuurlijk mijn achterban. Zonder sociaal nerwerk had ik deze drukke en soms toch wel stressvolle aio-periode nooit volgehouden. Lieve Geert (alias Will), jij was erbij vanaf de eerste dag dat ik in Maastricht ging studeren. We went to hell and back my friend! De tranen schieten nog steeds in mijn ogen als ik eraan denk hoe je me gesteund hebt gedurende mijn zickte. Jij kwam trouw jedere dag naar het zickenhus om me op te zocken en op te vrolijken. Zelfs toen de artsen de hoop al bijna hadden opgegeren, stond jij naast me. Ook al is de afstand nu een stuk groter, aangezien dokter Geert toch het liefst in Noorwegen ging werken, sta je toch weer aan mijn zijde, nu als paranimf. Ik had het me ook niet anders kunnen voorstellen. Love you, kus, Grace!

Ron, alias baas Maes, als opperhoofd op verdieping 2 van Vijverdal. besloot jij, dat ik, bij hoge uitzondering toegelaten werd tor het culinair gezelschap, ook al was het 
dan meer uit meelij met "dat scharminkel". Je groeide uit tot een lieve vriend waar ik altijd op kon bouwen en, die ervoor zorgde dat ik zeker in de drukke periodes niet vergat te eten.

Tammie, studiegenootje en lieve vriendin. Zonder enige schroom beken ik dat mijn eerste indruk van jou ontzettend verkeerd was! Ook jij stond en staat altijd voor me klaar, enne, altijd in voor een feestje. Je woont al in aantal jaren boven de rivieren, maar dat heeft onze vriendschap niet belemmerd. Heb je jouw stelling gezien?!

Elke, we kennen elkaar al sinds de middelbare school. Wat hebben wij al wat uurtjes weggekletst. Jij weet me altijd subtiel terecht te wijzen als dat weer eens nodig is. Ben blij dat je besloten hebt om in Maastricht te blijven wonen! Lieve Aggie, mijn tweede paranimf, onze geschiedenis mag dan niet zo heel lang zijn, bewogen zeker wel. Aan het einde van de dag altijd even de boel evalueren tijdens het naar huis fietsen, maar ook tijdens de vrijdag-bier-middagen, en de wijn avondjes. Florence was onvergetelijk en ik ben blij dat je daar instemde om mijn paranimf te zijn!

Oom Giel, dank je wel voor het aanleveren van computerprogramma's en het ter beschikking stellen van je computer toen ik daar verlegen om zat. Heb je er nog steeds niet van kunnen overtuigen dat niet alles in de genen zit, maar wie weet komen we daat ooit nog wel uit.

Lieve Koen, jij kwam mijn leven binnenstappen op een moment dat al mijn aandacht, energie en toewijding naar het afronden van mijn proefschrift uitgingen. Jij had geduld en waar mijn hoofd en hart op hol dreigde te slaan, zorgde jij voor rust. Dare to live dangetous(ly) with me! Kusje!

Tenslotte het thuisfront: de Curfs-clan. Ons gezin is het voorbecld van "samen staan we sterk". Judith (Leon en Wouter) en Nicolle (Wouter), dank jullie wel voor het begrip en de liefde die ik van jullie kreeg, ook al konden jullie soms het wat, warom en hoe niet helemaal volgen. Judith, een extra dank je wel roor alle hulp met het lay-outen. Leon, dank je wel voor het uitlenen van jourw computer. Nicolle en Wouter, de muis is perfect!

Lieve papa en mama, jullie zijn mijn nimmer aflatende rots in de branding. Jullie leerden me wat hard werken is en dat je alles kunt doen wat je maar wilt. Altijd zijn jullie er voor me!. Ik ben ontzettend trots op jullie!! Een dikke kus!

\section{Daniëlle}




\section{Curriculum Vitae}

\section{D.M.J. Curfs (Daniëlle)}

17 December 1976 born in Voerendaal.

\section{Education}

1989-1995

Gymnasium $\beta$, Bernardinuscollege, Heerlen

$1995-2000$

1998

1999

2001

2002

Environmental Health Sciences (MGK), University of Maastricht

Course on working with radiation level 5B

Licence for working with laboratory animals according to art. 9 of the Dutch law on laboratory animals.

Medical/Forensic Toxicology course (module of the Postgraduate Education in Toxicology).

Immunotoxicology course (module of the Postgraduate Education in Toxicology).

Research

$1997-2000$

Student-researcher, dept. of Health Risk Analysis \& Toxicology, University of Maastricht.

2000-2004 PhD-student (Prof. dr. F.J. van Schooten, Prof. dr. M.J.A.P. Daemen) depts. of Heaith Risk Analysis \& Toxicology and Pathology, University of Maastricht.

$2004-$ Postdoctoral Fellow dept. of Molecular Genetics (dr. M. De Winther and Prof. dr. M. Hofker). 


\section{List of Publications}

\section{Awards}

1. Poster Award, The Scientific Meeting of the Netherlands Society of Toxicology, November 2001, Nijmegen, The Netherlands.

\section{Full papers}

van Maanen JM, Albering HJ, van Breda SG, Curfs DM, Ambergen AW, Wolffenbuttel BH, Kleinjans JC, Reeser HM. Nitrate in drinking water and risk of childhood diabetes in The Netherlands. Diabetes Cart. 1999, 22(10): 1750.

2. Nia $A B$, Maas LM, van Breda SG, Curfs DM, Kleinjans JC, Wouters EF, van Schooten FJ. Applicability of induced sputum for molecular dosimetry of exposure to inhalatory carcinogens: 32P-postlabeling of lipophilic DNA adducts in smokers and nonsmokers. Canar Epidemiol Biomarkers Prev. 2000, 9(4): 367-72.

3. van Maanen JM, Albering HJ, de Kok TM, van Breda SG, Curfs DM. Vermeer IT, Ambergen AW, Wolffenbuttel BH, Kleinjans JC, Reeser HM. Does the risk of childhood diabetes mellitus require revision of the guideline values for nitrate in drinking water? Environ Healtb Perspect. 2000, 108(5): 457-61.

4. van Maanen JM, Albering HJ, de Kok TM, van Breda SG, Curfs DM, Ambergen AW, Wolffenbuttel BH, Kleinjans CJ, Reeser HM. Nitraat in drinkwater en risico voor type 1 diabetes in kinderen in Nederland. Nederlands Tijdschrift voor Geneeskunde 2000, 144:1272-1276.

5. Godschalk RW, Curfs DM, Bartsch H, van Schooten FJ, Nair J. Benzo|a|pyrene enhances lipid peroxidation induced DNA damage in aorta of apolipoprotein E knockout mice. Free Radic Researth. 2003, 37(12): 1299-1305.

6. Curfs DM. Beckers L, Godschalk RW, Gijbels MJ, van Schooten FJ. Modulation of plasma lipid levels affects benzo|a|pyrene-induced DNA damage in tissues of two hyperlipidemic mouse models. Environ Mol Muragen. 2003, 42(4): 243-9.

7. Curfs DM, Lutgens E, Gijbels MJ, Kockx MM, Daemen MJ, van Schooten F]. Chronic exposure to the carcinogenic compound benzo[alpyrene induces larger and phenotypically different atheroselerotic plaques in ApoE-knockout mice. Asm I Patbat. 2004, 164(1): 101-8.

\section{Scientific Meetings}

1. Curfs DM. Cramers P (organizing committec). The scientific meering of the Nerherlands Sociery of Toxicology. De Bilt, The Netherlands. January 2003

Curfs DM. Cramers $P$ (editors). Proceedings of the scientific meeting of the Netherlands Society of Toxicology, De Bilt, The Netherlands, Januacy 2003.

\section{Abstracts}

1. Curfs DM. van Schooren FJ. Kleinjans JC. The role of dietary mutagens in atherosclerosis. Proceedings of the scientific meeting of the Netherlands Society of Toxicology, Kerkrade, The Nerherlands, December 2000.

2. Cunfs DM. Lutgens E. Daemen MJ, van Schooten FJ. Induction of atheroseleresis in apoE-knockout mice exposed to benzo|alpyrene. Proceedings of the $31^{\text {s }}$ Annual Meering of the European Enviranmental Mutagen Sociery (EEMS), Gent, Belgium, September 2001.

3. Curfs DM. Lurgens E, Daemen MI, van Schooten F]. Inducrion of atherosclerosis in apoE-knockout mice exposed to benzolajpyrene. Proceedings of the scientific meeting of the Netherlands Society of Toxicology, Nijmegen. The Nerherlands, November 2001. 
4. Curfs DM. Beckers L, Godschalk RW, van Schooten F. The role of diet in benzo[alpyrene-induced DNA damage in atherosclerotic mouse models. Proceedings of the $93^{\text {rd }}$ annual meeting of the American Association for Cancer Research (AACR), San Francisco, USA, A pril 2002.

5. Curfs DM, Lutgens E, Daemen MJ, van Schooren F. The environmental carcinogen benzo|a|pyrene enhances plaque progression in apoE-KO mice. Proceedings of the scientific mecting of the American Heart Association, Chicago, USA, November 2002. Supplement to Girculation. 2002, 106(19): SII-183.

6. Curfs DM, Lutgens E, Gijbels MJ, Daemen MJ, van Schooten FJ. The environmental carcinogen benzo[a]pyrene enhances plaque progression in apoE- $\mathrm{KO}$ mice. Proceedings of the scientific meeting of the Nerherlands Society of Toxicology, De Bilt, The Netherlands, January 2003.

7. Curfs DM, Lutgens E, Godschalk RW, Knaapen AM, Beckers L, Gijbels MJ, Daemen MJ, van Schooten FJ. Benzo[a]pyrene enhances atherosclerosis in apolipoprotein E knockout mice. Proceedings of the 19th International Symposium on Polycyclic Aromatic Compounds, Amsterdam, The Netherlands, September 2003.

8. Curfs DM, Knaapen AM, Creemers E, Godschalk RW, van Schooten FJ. Polycyclic aromatic hydrocarbons cause intracellular oxidative stress in murine monocyte/macrophage-like cells: possible link to atherogenesis. Proceedings of the 19th International Symposium on Polycyclic Aromatic Compounds, Amsterdam, The Netherlands, September 2003.

9. van Haaften RI, Curfs DM, Daemen MJ, van Schooten FJ, Evelo, ChT. Annotation of agilent mouse oligo array content used to evaluate benzo[a|pyrene effects in a physical content. Proceedings of the 6th International Meeting of the Microarray Gene Expression Data Society, Aix-en-Provence, France, September 2003.

10. Godschalk RW, Curfs DM, Bartsch H, van Schooten FJ, Nair J. Benzo[alpyrene enhances lipid peroxidation induced DNA damage in aorta of apolipoprotein E knockout mice. Proceedings of the 19th International Symposium on Polycyclic Aromatic Compounds, Amsterdam, The Netherlands, September 2003.

11. Curfs DM, Beckers L, Godschalk RW, Gijbels MJ, van Schooten FJ. Modulation of plasma lipid levels affects $\mathrm{B}[\mathrm{a}] \mathrm{P}$-induced DNA damage in tissues of two hyperlipidemic mouse models. Abstracts of the $41^{\text {t }}$ Congress of the European Societies of Toxicology, Florence, Italy, September 2003. Toxiology Letters. 2003, 144(\$1): \$93. 


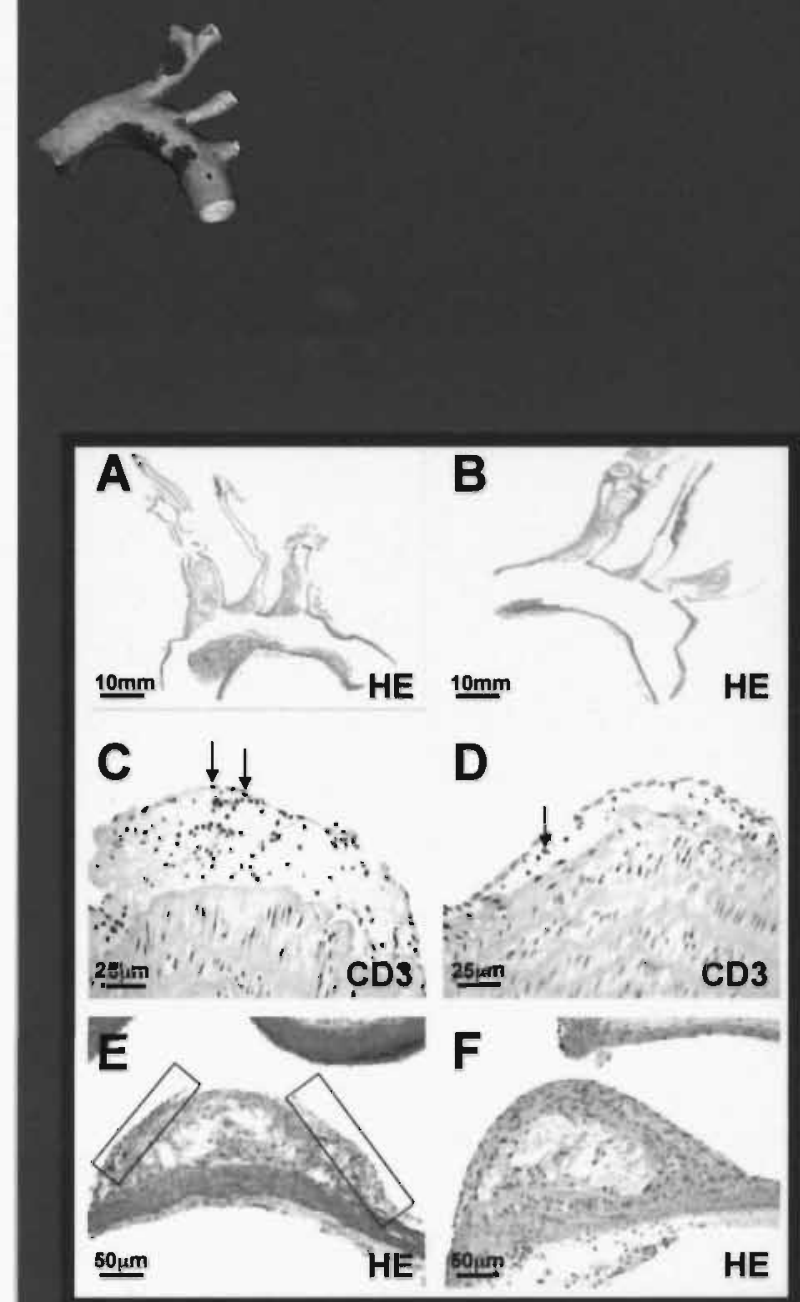

Figure 4.2

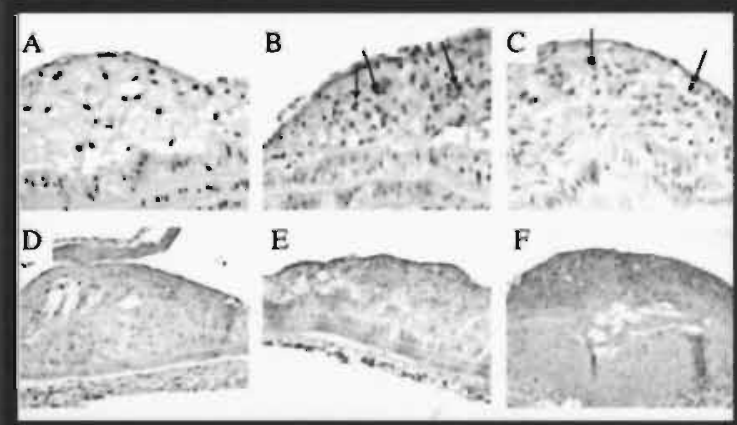

Figure 5.3 
